\title{
(Debt) Overhang: Evidence from Resource Extraction
}

\author{
Michael D. Wittry
}

\begin{abstract}
A dissertation
submitted in partial fulfillment of the

requirements for the degree of
\end{abstract}

Doctor of Philosophy

University of Washington

2020

Reading Committee:

Jonathan M. Karpoff, Chair

Ran Duchin

Jarrad Harford

Edward Rice

Program Authorized to Offer Degree:

Foster School of Business 
(C) Copyright 2020

Michael D. Wittry 
University of Washington

\author{
Abstract \\ (Debt) Overhang: Evidence from Resource Extraction \\ Michael D. Wittry \\ Chair of the Supervisory Committee: \\ Professor Jonathan M. Karpoff \\ Department of Finance and Business Economics
}

I study the empirical importance of debt overhang using a unique dataset on resource extraction firms, which provides ex ante measures of investment opportunities and important variation in the terms of a firm's obligations. In particular, unsecured reclamation liabilities create overhang that is costly to resolve and induces firms to forgo and postpone positive NPV investments. Traditional debt, in contrast, imposes few overhang-related investment distortions. These results show that: (i) the overhang problem is potentially large and applies more broadly to a firm's non-debt liabilities; and (ii) overhang problems associated with traditional debt can be avoided through contracting and debt composition. 


\section{ACKNOWLEDGMENTS}

I would like to express my most sincere gratitude to the individuals that made the completion of my graduate studies, and by extension, this dissertation possible. First and foremost, I would like to thank the chair of my supervisory and reading committees, Jon Karpoff, for unceasing support for the last six years. Jon represents everything that I believe is great about academics: an unquenchable thirst for truth and science, a career-long effort to expand the frontier of knowledge, and above all else, genuinity, humility and respect for this profession and everyone in it. It is difficult to express how much I have benefited from his guidance. Beyond this, Jon and his family, have truly become great friends and constant cheerleaders in the trials and tribulations of our life.

I am also indebted to the other members of my committee: Krzysztof Burdzy, Ran Duchin, Jarrad Harford, Edward Rice, and Jacob Vigdor. Each provided support in the obvious ways. However, and I believe just as importantly, each encouraged my progress through unique and non-obvious ways. From the periodic comedic relief to the immensely beneficial RA'ships, my development would not have been the same without their input.

The next two people are listed below my committee members, but without them, I would have never made it to the dissertation stage. Alvin Chen and Rui Han were my cohort mates and were absolutely essential to me in passing microeconomics and my comprehensive exams. They are also two of my best friends who were always willing to lend a helping hand or provide a pick-me-up. I will never forget the countless hours we spent studying in McKenzie 367, and just as Ed predicted, I am beginning to fondly recall our time in PACCAR preparing for the tools exam. 
To all those at the University of Washington, and in particular, in the Finance and Business Economics department, thank you for the investment you made in my academic future. While there are so many of you that I cannot possibly list you all, I do want to highlight the contribution of the following individuals: Philip Bond, Aaron Burt, Matt Denes, Quentin Dupont, John Hackney, Jennifer Koski, Tarun Patel, and Mark Westerfield. I gratefully acknowledge the financial support provided by the Journal of Financial and Quantitative Analysis, Verus Financial, and Russell Investments.

Finally, I would be remiss if I did not mention my amazing family. To my parents, Dave and Mary, thank you for always believing in me. To my brother, Matt, and my sister, Beth, thank you for being my best friends. Everything in my life, including academics, has been dependent on the love and support of you four. 


\section{DEDICATION}

to my amazing, loving wife, Sarah, and our incredible children, Anna, Asher, and Jude, you are my everything, without you none of this would be possible 


\section{Introduction}

Debt overhang is a pillar of corporate finance theory. Myers (1977) demonstrates that existing debt obligations have the potential to induce underinvestment in valuable growth options, as the benefit of investing in such projects primarily accrues to debtholders. Establishing the importance of debt overhang in capital structure decisions is difficult, however, because contracting and debt composition mechanisms endogenously arise to mitigate its effects. In addition, fully identifying the costs of overhang requires observing the firm's investment opportunity set. This paper exploits a novel setting that allows me to both disentangle the costs of overhang from its potential solutions, and observe the firm's ex ante investment opportunity set.

I focus on a sample of Canadian resource extraction firms that provides ex ante estimates of the net present value (NPV) of a firm's new mining projects. In December 2000, the Ontario Securities Commission passed regulation that significantly increased disclosure requirements for publicly listed mining firms, notably requiring firms to file technical reports on mining projects that include an estimate of the project's NPV. These feasibility reports enable me to see exactly when firms take positive NPV projects, and more importantly, when they forgo or postpone them.

The resource extraction setting also allows me to directly compare two types of liabilities, traditional debt and mine reclamation liabilities, which differ in the costs associated with avoiding overhang. ${ }^{1}$ The overhang-related investment distortions induced by traditional debt can be mitigated at relatively low cost by firms avoiding debt altogether, issuing short maturity debt, renegotiating the contract ex post (Myers, 1977), or securing their debt issuances (Stulz and Johnson, 1985). In contrast, applying such solutions to mine reclamation liabilities is significantly more costly. In particular, resource extraction firms cannot employ the most obvious solution to the traditional debt overhang problem - finance projects solely

\footnotetext{
${ }^{1} \mathrm{~A}$ mine reclamation liability is the obligation of a mining operator to restore disturbed mining land to a natural or economically usable state after the productive life of a mine.
} 
through equity. Rather, the production function of these firms dictates the creation of reclamation liabilities in order to extract valuable minerals from the ground. Beyond this, it is very difficult for firms to shorten the maturity of reclamation liabilities or to favorably renegotiate the terms of the obligation ex post.

The nature of mining regulations also enables me to observe the importance of secured liabilities. Over time most jurisdictions have implemented legislation that requires mining operators to financially guarantee, or bond, their reclamation liabilities. However, the accepted forms of these guarantees vary substantially across jurisdictions. Most can be generally classified into a group that requires explicit collateral (externally-bonded) or a group that does not (self-bonded). I exploit the differences in local bonding regulations around the world to identify plausibly exogenous variation in self-bonding, and to separate reclamation liabilities into a treatment group (self-bonded) that is comparable to unsecured debt, and a control group (externally-bonded) that is comparable to secured debt.

Using the data in Table 1, I define a self-bonded mine as any mine permitted during a year self-bonding is allowed. All other mines are classified as externally-bonded. Each year, I sum the estimated reclamation liabilities of a firm's self-bonded and externally-bonded producing mines to get a total dollar amount for each type of reclamation liability. I create two sets of empirical measures of firms' exposure to the overhang problem. The first set consists of market leverage ratios, or the dollar amount of debt, self-bonded and externallybonded reclamation liabilities, respectively, divided by the market value of assets of the firm (Frank and Goyal, 2009). The second is a group of indicator variables equal to 1 if a firm's existing liabilities exceed the potential value added by a new mining project. These indicators identify the growth options that go unfunded in Myers' baseline model.

These empirical measures of overhang allow me to distinguish the impact of each respective liability on a firm's propensity to invest in new mineral projects. Mineral projects are well suited for studying overhang as they require two pre-production investments, one upfront to acquire the mining rights and a second in infrastructure and capital directly before 
production begins. The initial investment in the mining rights can be viewed as a growth option that expires immediately if the investment is not made. If a firm acquires the rights to extract the mineral, however, the project represents a second real option that is exercised when the firm makes the secondary investment and begins production. Myers' (1977) model shows the costs of overhang arise from firms completely forgoing investment in growth options that immediately expire, while in both Mello and Parsons (1992) and Mauer and Ott (2000), the loss of value due to debt overhang stems from firms suboptimally delaying exercise of the real option. Mineral projects allow me to test the implications of both aspects of debt overhang theory.

Consistent with each, I find that when firms are unable to avoid the overhang problem efficiently, they both forgo and postpone positive NPV mining projects. Specifically, selfbonded reclamation liabilities negatively impact the likelihood a firm acquires new positive NPV mining rights, while externally-bonded reclamation liabilities and traditional debt liabilities do not. Further, I find that only firms with large exposures to self-bonded reclamation liabilities are significantly more likely to delay construction on positive NPV mining projects.

The fact that traditional debt imposes few overhang-related distortions does not mean debt overhang is unimportant in capital structure decisions. Rather, taken together, the results highlight exactly how important the agency costs of debt overhang are and why effective solutions have endogenously arisen to avoid them. Further, if we assume that a dollar of reclamation liability imposes similar overhang as a dollar of traditional debt, the ex post costs of overhang imposed by mine reclamation liabilities provide an upper bound estimate of the ex ante contracting costs of avoiding overhang from traditional debt, or the shadow costs of debt overhang.

My results indicate that these costs are nontrivial. In particular, firms passing on positive NPV mining rights translates to an expected loss in value of roughly $\$ 0.601$ million each year. Additionally, for firms with self-bonded reclamation liabilities that exceed the potential value of a new project, the average delay in construction is nearly two years. In time value of money 
terms, this equates to an expected loss of nearly a $\$ 1.1$ million each year. Given the average reclamation liability in my sample is held for 20 years, the present value of these annual costs roughly aggregated together is $\$ 17.40$ million, or $6.34 \%$ of market value for the median firm with at least one producing mine.

The inferences in my paper are robust to a number of alternative mechanisms, model specifications, and endogeneity concerns. Further, consistent with theory, the effect is more pronounced when firms' liabilities are plausibly more risky (Myers, 1977) and short-maturity liabilities seemingly impose additional costs for high asset volatility firms in bad times (Diamond and He, 2014). Importantly, I also verify that the results from more traditional tests of debt overhang are similar in my sample. Specifically, I find a strong negative relation between capital expenditures and a firm's traditional debt leverage ratio, despite my baseline finding that traditional debt is unrelated to investment in positive NPV projects. Together, these results suggest that previous studies that find a negative relation between leverage ratios and CapEx do not necessarily identify a debt overhang effect. Instead, the negative relation may identify a decrease in the firm's investment opportunity set or even a decrease in negative NPV projects.

My paper makes three contributions to the corporate finance literature. First, I document that overhang imposes significant costs. However, my results indicate that self-bonded reclamation liabilities, and not traditional debt, negatively impact investment in mining projects that are shown to be valuable ex ante. This suggests that firms incur much of the costs of overhang ex ante through contracting and debt composition solutions rather than ex post through investment distortions. Other recent studies have also highlighted the importance of debt overhang. For example, Melzer's (2017) and Bernstein's (2019) findings imply that the overhang problem is not confined to the corporate setting. Additionally, the ex ante NPV estimates allow me to roughly estimate the costs of overhang in a reduced-form way. Much of the evidence from structural models suggests that debt overhang may not be a first-order concern in capital structure decisions as the estimated agency costs are typically 1-2\% of 
market value. ${ }^{2}$ My results, however, suggest that the costs (6.34\% of market value) could be even larger than the structural estimates in Titman and Tsyplakov (2007) and Moyen (2007).

Second, this paper contributes to the literature on potential solutions to asset substitution and debt overhang problems. In recent empirical work, both Gilje (2016) and Denes (2017) argue that covenants, debt composition and other economic mechanisms are efficient in reducing the incentives of firms to engage in risk-shifting. These papers offer considerable insight into the struggle to identify empirical evidence of Jensen and Meckling's (1976) asset substitution problem. The evidence on avoiding debt overhang is currently more segmented. For example, a branch of the literature concentrates only on renegotiation. ${ }^{3}$ In fact, in one of the most well-executed empirical approaches, Giroud et al. (2012) show that the renegotiation of debt contracts substantially improves a firm's operating performance. My results both compliment Giroud et al.'s (2012) and extend them. That is, renegotiation is just one of the several potential resolutions to the debt overhang problem, and my results indicate that firms utilize this entire collection of costly yet effective solutions, even outside of debt restructurings.

Lastly, this paper complements a growing strand of literature that focuses on the importance of a firm's non-debt obligations. Similar to prior studies on pension (Rauh, 2006) and legal (Arena and Julio, 2015; Bennett et al., 2018) liabilities, I show non-debt liabilities have a first-order effect on firm investment policy. ${ }^{4}$ Further, both Rauh (2009) and Akey and Appel (2020) document evidence of the effect non-debt liabilities can have on manage-

\footnotetext{
${ }^{2}$ E.g., see Mello and Parsons (1992), Parrino and Weisbach (1999), Mauer and Ott (2000), Hennessy (2004), and Childs et al. (2005).

${ }^{3}$ E.g., see Aivazian and Callen (1980), Gertner and Scharfstein (1991), Mella-Barral and Perraudin (1997), Pawlina (2010), and Chu (2019). There is also a branch that focuses only on debt maturity. For example, Barclay and Smith (1995), Guedes and Opler (1996) and Barclay et al. (2003) find a negative correlation between debt maturity and growth opportunities, while Johnson (2003) shows that short debt maturity attenuates the negative relationship between leverage and growth opportunities. Additionally, Billett et al. (2007) focus on the endogenous evolution a firm's growth options with respect to leverage, debt maturity and covenants and Diamond and He (2014) analyze the specific conditions in which short maturity debt will lead to lower overhang.

${ }^{4}$ While Rauh (2006), Arena and Julio (2015), and Bennett et al. (2018) each have a different mechanism in mind, their results are consistent with an overhang channel.
} 
rial risk-shifting behavior. Finally, Chen et al. (2018) and Chang et al. (2018) show that operating leverage and corporate environmental liabilities, respectively, are substitutes for traditional debt liabilities.

\section{Institutional Setting}

\subsection{Resource Extraction in Canada}

Canada consistently ranks among the world leaders in the global production of minerals and metals (Marshall, 2017). Due to this rich geology, a substantial number of resource extraction firms locate in Canada and ultimately list on either the Toronto Stock Exchange (TSX) or TSX Venture Exchange (TSXV). For example, according to the National Resource Governance Institute, the TSX and TSXV account for 31\% of the world's public mining firms, and $15 \%$ of the global mining market value. Further, Richer La Flèche et al. (2016) report that more mining companies are listed on the TSX and TSXV than on any other exchange in the world.

Beyond the size of the public resource extraction industry in Canada, this setting offers an even more significant advantage. Following the Bre-X mining scandal in the 1990s, the Ontario Securities Commission introduced the National Instrument 43-101 Standards of Disclosure of Mineral Projects, a listing requirement for both the TSX and TSXV (Fox, 2017). ${ }^{5}$ Upon their implementation in 2003, the main tenets of National Instrument 43101 (NI 43-101) standardized the reporting of all scientific and technical information, and required this information to be prepared by or under the supervision of a "qualified person". The qualified person must have a mining-specific academic and career background, among other credentials, and is liable for the content of the NI 43-101 technical reports (Fox, 2017). ${ }^{6}$

These reports are "a summary of material scientific and technical information concerning

\footnotetext{
${ }^{5}$ Documentation on National Instrument 43-101 Standards of Disclosure on Mineral Projects can be found at http://web.cim.org/standards/documents/block484_doc111.pdf.

${ }^{6}$ Holding the qualified person liable for the content of the report eases concerns of large misrepresentations in the NPV estimates.
} 
mineral exploration, development, and production activities on a mineral property that is material to an issue" (Ontario Securities Commission, 2011). They include highly detailed information on the property itself, as well as resource (measured \& indicated and inferred) and reserve quantities (both proven and probable), and the potential economic viability of the project. The economic viability is analyzed in a series of reports (preliminary economic assessment (PEA), the pre-feasibility report, and the feasibility report). Each is required to include capital and operations cost estimates, estimated mine life, forecasted production and revenues, and the overall estimated NPV of extracting the mineral.

These data are extremely rich and allow me to directly test Myers' (1977) prediction that firms will pass on positive NPV projects. It is possible, however, that the NPV estimates are uninformative or inaccurate. In recent studies on voluntary disclosure of gold feasibility studies in Australia, Ferguson and Pündrich (2015) and Ferguson et al. (2013) find that the technical reports contain information used by investors, suggesting these types of reports are at least partially informative. In support of these findings, Figure 1A shows investors do react positively to the disclosure of the report containing initial NPV estimates.

More importantly, Table 2 and Figure 1B explore the relationship between the NPV estimate relative to the firm's lagged market capitalization and the abnormal returns around the disclosure of the report. While the estimated coefficients are small, both the table and the figure suggest that investors believe a higher NPV estimate means a higher project value. ${ }^{7}$ Further, Figure 1B highlights that investors do not react to the relative size of the NPV estimate until day 0 , indicating the estimate is not fully expected and there is a reaction to the value estimate itself above and beyond any reaction simply to the report being released.

Verifying the ex post accuracy of the NPV estimates directly is nearly impossible, particularly for recently started projects such as those in my sample. However, the data allow

\footnotetext{
${ }^{7}$ The fact that the coefficients are small is unsurprising due to the substantial amount of information released about the mineral deposit prior to the disclosure of the NPV estimate. Typically investors will have access to geological descriptions, drilling results and even scoping technical reports prior to the first feasibility study. With this information, investors likely have constructed a reasonable forecast of the extraction value. For example, the surface area of the mineral deposit alone explains over $30 \%$ of the variance in NPV in my sample.
} 
me to examine the quality of the annual production forecasts contained in the reports and used in creating the capital budgeting tables. Figure 2 plots the forecasted annual production against the average realized annual production for both total ore (Panel A) and the metal contained in ore (Panel B) for accepted projects. Ex post, the forecasts look incredibly accurate, with correlation coefficients of $83 \%$ and $86 \%$, respectively, and normalized root-mean-square errors $15 \%$ and 9.5\%, respectively. Overall, this evidence supports the argument that the NPV estimates are likely to be both informative and accurate.

\subsection{Mine Reclamation and Financial Assurance}

Mining regulations and regulatory bodies display significant heterogeneity around the world (e.g., see Richer La Flèche (2016)). Nearly unanimously, however, regulators direct mining operators to disturb as little land as possible, and to reclaim the disturbed areas when extraction is complete. While reclamation standards vary among different jurisdictions, most include an extensive amount of work to be completed after the productive life of a mine. ${ }^{8}$ Because this creates a substantial, long-term obligation for mining operators, most jurisdictions require mining operators to post financial assurance, or a bond, that ensures the costs of reclamation will be borne by the mining company and not by the local government and taxpayers. There are essentially four main types of financial assurance - surety bonds, collateral bonds, letters of credit, and self-bonds - and the types that are deemed acceptable vary substantially across jurisdictions and through time. ${ }^{9}$

These first three methods of bonding are costly ex ante for the mining operators. Surety bonds tend to be the most common method, particularly in the U.S. (Gorton, 2009; Nazzaro, 2005), and survey evidence indicates that premiums in the U.S. can range from 1-3.5\%

\footnotetext{
${ }^{8}$ This often includes, but is not limited to, demolition of existing mining structures; sealing and stabilization of pits and shafts; recontouring of access roads, tailing ponds, trenches, pits and shafts; revegetation; and monitoring and evaluation of the site. For a checklist that details reclamation standards in the U.S., see Bureau of Land Management (2005).

${ }^{9}$ This list does not include some less common forms of financial assurance accepted by certain jurisdictions. For example, some states/provinces and countries have what is called a bond pool, where mining operators each contribute to a government sponsored pool which is used to perform reclamation. For more information on reclamation bonding options, see Cheng and Skousen (2017), Gorton (2009), and Nazzaro (2005).
} 
(Kuipers, 2000) to 5-6\% (Chelimsky, 1988) with up to a 100\% collateral requirement. Recent anecdotal evidence also suggests that surety bonds can be extremely costly. Bonogofsky et al. (2015) report that Cloud Peak Energy saved upwards of $\$ 2$ million per year switching from surety to self-bonds. Letters of credit and collateral bonds, on the other hand, often have negligible annual premiums, but firms typically post $100 \%$ collateral into cash trusts or certificate of deposits for collateral bonds, and banks can require collateral deposits of upwards of 120-200\% of total estimated liability for letters of credit (Kirschner and Grady, 2003). Thus, there are significant liquidity costs associated with letters of credit or cash bonds.

Unlike the first three bonding methods, a self-bond does not necessitate explicit collateral. Rather a self-bond requires that an operator, its parent, or a third-party provide a legallybinding guarantee for the cost of reclamation. Because of financial and credit-worthiness criteria, mining operators often have a difficult time qualifying for a self-bond. ${ }^{10}$ Further, if an applicant intends to use a non-parent corporate guarantee in the U.S., the conditions apply to both the applicant and the corporate guarantor (Mayhall, 2018). Thus, the overwhelming majority of self-bonds are parent guarantees, often called corporate or company guarantees (Nazzaro, 2005).

\subsection{Contracting Costs}

There are several potential yet costly solutions to the overhang problem. First, a firm can simply choose to finance its projects through equity rather than debt and avoid the overhang problem altogether. Additionally, Myers (1977) notes that debt overhang can be resolved through a policy of (non-automatically) rolling over short maturity debt claims, or ex post

\footnotetext{
${ }^{10}$ For example. 30 C.F.R. $\$ 800.23$ requires applicants for self-bonds in the United States to 1) have been in continuous operation as a business entity for a period of not less than five years, 2) a current rating for its most recent bond issuance of ' $\mathrm{A}$ ' or higher, or a tangible net worth of at least $\$ 10$ million (or fixed assets in the U.S. of $\$ 20$ million), a ratio of total liabilities to net worth of 2.5 times or less and a ratio of current assets to current liabilities of 1.2 times or greater, and 3) total amount of outstanding and proposed self-bonds may not exceed $25 \%$ of the applicant's tangible net worth. In Section I of the Internet Appendix, I use this criteria to probe the assumption that all firms self-bond when the law permits it.
} 
through renegotiation. Finally, Stulz and Johnson (1985) suggest that the use of secured debt can mitigate the underinvestment problem.

Reclamation liabilities offer a unique instrument to study these potential solutions as the costs of implementing the first three listed above are significantly higher than they are for traditional debt. ${ }^{11}$ For example, while not costless to finance solely through equity, the option nevertheless exists and is often exercised by firms (e.g., see Strebulaev and Yang (2013)). This option, however, is not applicable to reclamation liabilities. For any resource extraction firm wishing to extract minerals from the ground, a reclamation liability is simply part of the production function that cannot be avoided.

Diamond (1991, 1993) and Sharpe (1991) point out that short maturity debt contracts impose costs due to liquidity risk. Even so, firms continue to issue large amounts of short maturity bonds. For example, Saretto and Tookes (2013) and Xu (2017) find that the average maturity for U.S. corporate bonds and speculative grade bonds, respectively, in samples concentrated in the 2000s is around 8.7 years. Further, Custódio et al. (2013) report that less than $20 \%$ of the median firm's total debt outstanding has a remaining maturity greater than five years. Both of these studies highlight that firms regularly issue and maintain effectively short maturity debt, suggesting the potential overhang costs of long maturity debt exceed the costs of liquidity risk from short maturity debt.

On the other hand, the average mine in my sample has a productive life greater than 20 years, creating a liability with more than twice the maturity as the average bond. Strategically choosing short-life mines ex ante is likely to be extremely costly, as the life of a mine is highly correlated with the amount of mineral contained in the deposit and thus the NPV of the project. Additionally, because "retiring" a mine reclamation liability involves closing and reclaiming a mine, shortening the maturity of current a mine reclamation liability even by a few years could mean sacrificing millions of dollars in valuable resource extraction and

\footnotetext{
${ }^{11}$ Additionally, my identification strategy (discussed below in Section 3.1) allows me to separate secured and unsecured mine reclamation liabilities. For a discussion on the bankruptcy priority of reclamation liabilities in U.S., see Internet Appendix Section II.
} 
production.

The best evidence of the costs of renegotiating debt contracts is the sheer prevalence with which renegotiation takes place. For example, Roberts (2015) finds that the average bank loan is renegotiated 3.5 times, while Roberts and Sufi (2009) report that 90\% of private credit agreements are renegotiated prior to their original maturity. Further, Nikolaev (2018) finds that the unconditional probability a firm renegotiates at least one contract in a given year is $37 \%$. Taken together, the results in these studies suggest that the overall costs of renegotiation for traditional debt are likely not prohibitive. This does not mean, however, that renegotiating debt contracts is never costly. For example, Chu's (2019) findings imply that syndicate loans with many lenders are more costly to renegotiate. This suggests that there is heterogeneity in the costs of avoiding overhang even in the cross-section of traditional debt contracts. ${ }^{12}$

Mine reclamation liabilities, on the other hand, appear significantly more difficult to renegotiate ex post in a way that mitigates overhang. First, while traditional debt contracts can be renegotiated on price, level, maturity, or specific covenants, mine reclamation liabilities can only be renegotiated on level. Second, adjusting the level of a mining firm's liability down requires local regulators to transfer the obligation from large mining firms to local taxpayers. Third, it is unclear if regulators have the authority to renegotiate in all jurisdictions (e.g., see Socalar (1988)). Lastly, while reclamation liabilities and their associated bonds are often negotiated up, (e.g., see Walsh (2017)), using a comprehensive news search, I cannot find evidence of a single anecdote in which a reclamation liability is renegotiated down to a point that it no longer accurately represents the expected costs. All of this evidence supports the argument that reclamation liabilities have renegotiation costs that exceed those of traditional debt.

\footnotetext{
${ }^{12}$ Indeed, Internet Appendix Table IA1 supports this hypothesis using the sample from Table 5 below.
} 


\section{Empirical Strategy and Data}

\subsection{Identifying Reclamation Liabilities}

The difference in contracting costs between traditional debt and reclamation liabilities allows me to assess the importance of debt overhang through a direct comparison of the different liabilities' impact on investment policy. While traditional debt is defined simply as the sum of a firm's book value of total long-term debt and the book value of debt in current liabilities, defining a firm's exposure to reclamation liabilities is more complex. Estimated reclamation liabilities are reported in project technical reports; however, even with the high disclosure standards, firms are not required to disclose the manner in which their reclamation liabilities are bonded. Rather, I exploit the cross-section and time-series variation in self-bonding regulations to identify plausibly exogenous variation in firms' ability to self-bond their mine reclamation liabilities. ${ }^{13}$ This variation allows me to separate reclamation liabilities that must be backed by explicit collateral.

Table 1 displays all self-bonding regulations for which I can locate documentation. These regulations cover over $90 \%$ of the permitted mines in my sample. In Australia and Canada, individual states and provinces, respectively, set bonding laws, while the U.S. federal government regulates financial assurance provisions that are specific to the mineral to be extracted. Namely, the Surface Mining Coal Reclamation Act (SMCRA) of 1977 regulates coal mining, while 43 C.F.R $§ 3809$, passed in 2001, amended legislation for hardrock and metal mining. However, both federal provisions give states the option to be more stringent, that is, to prohibit self-bonding if the federal law allows it. ${ }^{14}$ Like 43 C.F.R $\S 3809$, most of the min-

\footnotetext{
${ }^{13}$ Section 5.1 explores potential endogeneity concerns with this idnetification strategy.

${ }^{14} 43$ C.F.R $\S 3809$ amended the law to prohibit new self-bonds but explicitly grandfathered existing selfbonded mines to that form of financial assurance. Thus, producing hardrock and metal mines were not required to provide additional financial assurance after the change. In other legislative changes around the world, it is much more difficult to discern the existence of and details regarding a grandfather provision. In this paper, I assume all current self-bonded mines are grandfathered in at the point of the law change, only needing to be re-bonded with a new form of financial assurance if the mine owner changes. This is the more conservative approach as this assumption limits presumably exogenous variation in self-bonded reclamation liabilities.
} 
ing regulations in Table 1 are part of a country's or state's mining reform, where previous legislation had required mines to be reclaimed without requiring financial assurance. For my empirical tests, I assume any legislation that requires reclamation without a bonding requirement (e.g. before Ghana's 1999 EPA Act or after Argentina's 1997 Mining Act) is equivalent to explicitly allowing self-bonding, as the incentive to complete reclamation is similar.

Under these assumptions, I define a mine as self-bonded if it was permitted in a state, province, or country, and in a year in which a self-bond or corporate guarantee was considered an acceptable form of financial assurance. All other mines are classified as externally-bonded. This definition is analogous to assuming that mining companies choose to self-bond whenever they are able. ${ }^{15}$ This seems reasonable for a few reasons. First, the other forms of financial assurance are costly ex ante. Annual premiums and collateral requirements can add millions of dollars to estimated reclamation costs. Second, the evidence supports the argument that the option to self-bond is heavily exercised (e.g., see Interstate Mining Compact Commission (2014) and Nazzaro (2005)). Indeed, Internet Appendix Figure IA1 shows the correlation between self-bonded reclamation liabilities created under this assumption and a measure of self-bonded reclamation liabilities inferred from Canadian firms' annual reports is nearly 80\%. Finally, the fact that some mines defined as self-bonded in my sample are not actually guaranteed through a self-bond should bias me against finding significant results.

Each self-bonded and externally-bonded mine in some stage of production contributes to a firm's overall self-bonded and externally-bonded reclamation liabilities, respectively. Using the definition of a self-bonded mine above, a firm's self-bonded liabilities in a given year are comprised of the estimated reclamation liabilities for all of its producing self-

\footnotetext{
${ }^{15}$ This assumption is discussed in more detail in Section I of the Internet Appendix. Tables IA2 and IA3 examine results when identifying subsets of reclamation liabilities that are more likely to be self-bonded. In particular, self-bonded reclamation liabilities created when a firm appears to be financial constrained (Table IA1), and self-bonded liabilities created under the standards set by U.S. 30 C.F.R. $§ 800.23$ (Table IA2) yield results similar to those in Section 4. Table IA4 analyzes a small secondary sample of U.S. mining firms that voluntarily disclose the amount of their reclamation liabilities and method of financial assurance in annual reports. These results verify the negative correlation between self-bonded reclamation liabilities and investment using capital expenditures as a proxy.
} 
bonded mines. I use the short-hand notation SB to represent the total U.S. dollar amount of a firm's self-bonded reclamation liabilities in a given year. Formally, this is $\mathrm{SB}_{t}=$ $\sum_{i \in \mathrm{P}, \mathrm{S}} E\left[\right.$ Reclamation liability $\left.{ }_{i t}\right]$, where $P$ represents mines in production, $S$ represents mines defined as self-bonded, and the estimated reclamation liability is reported in the technical reports prior to the mine being permitted. Similarly, EB represents the total U.S. dollar amount of a firm's externally-bonded reclamation liabilities in a given year. Formally $\mathrm{EB}_{t}=\sum_{i \in \mathrm{P}, \mathrm{E}} E\left[\right.$ Reclamation liability $\left._{i t}\right]$, where again $P$ represents mines in production, but $E$ represents mines defined as externally-bonded. These definitions of a firm's self-bonded and externally-bonded liabilities assume that once a mine is closed, the firm is no longer exposed to the liability. ${ }^{16}$ This assumption alleviates concerns due to a particular financial constraint in which firms with self-bonded reclamation liabilities cannot fund new investment due to their ongoing clean-up costs.

Figure 3 presents an example of three coal mines located near the border of British Columbia and Alberta, Canada. Transalta permitted Highvale Coal Mine in Alberta in 2007. Because Section 21 of the Alberta Conservation and Reclamation Regulation, passed in 1993, permits self-bonds, the $\$ 42.1 \mathrm{M}$ in estimated reclamation costs for Highvale is added to SB for Transalta when Highvale entered production in 2008.

Teck Resources permitted the other two mines, Greenhills Coal Mine and Elkview Coal Mine, in British Columbia in 1992 and 2008, respectively. Section 30 of British Columbia's Bonding Act, passed in 1996, prohibits self-bonding. Because of the timing of the regulation in British Columbia, the $\$ 153.2 \mathrm{M}$ in estimated reclamation costs for Greenhills is added to SB for Teck Resources when Greenhills began production in 1993, and the $\$ 53.4 \mathrm{M}$ in estimated reclamation costs for Elkview is added to EB when Elkview continued production in 2009 after being acquired by Teck Resources. ${ }^{17}$ All three of these mines are still in production

\footnotetext{
${ }^{16}$ This is equivalent to making the assumption that mining firms begin reclamation as soon as a mine is closed. The results are robust to alternative assumptions, such as the liability persists for 1 , 2 , or 3 years after ceasing production.

${ }^{17}$ Because of the time-series variation in regulations, even the same mine can be defined as self-bonded and externally-bonded over different parts of the sample if ownership changes following the passage of new regulation. For example, Highvale Coal Mine could be defined as externally-bonded if Teck Resources
} 
today and so are still considered liabilities for the respective companies at the end of my sample in 2016 .

\subsection{Empirical Measures}

In an ideal empirical setting to test debt overhang, a researcher would use exogenous variation in the value of a firm's option to default on their obligation (Merton, 1974) to study the impact on investment. Unfortunately, the value of a firm's put option is not directly observable. Thus, to facilitate the comparison between traditional debt and mine reclamation liabilities and analyze their impact on investment, I use two separate empirical measures that should be positively correlated with the value of the firm's option to default.

The first measure can essentially be thought of as a leverage ratio. For traditional debt, it is the market debt leverage ratio as defined in Frank and Goyal (2009). That is, debt leverage is a firm's traditional debt divided by the market value of its assets. ${ }^{18}$ For reclamation liabilities, the denominator of market value of assets remains the same, but traditional debt is replaced by $\mathrm{SB}$ or EB, the total dollar amounts of a firm's respective reclamation liabilities. Thus, the "leverage" ratios for self-bonded and externally-bonded reclamation liabilities are $S B / M V$ and $E B / M V$, respectively. While leverage ratios are commonplace in studying debt overhang, there is no strong theoretical basis for why debt or other obligations would impact firms' option to default, and ultimately investment policy in a linear way. Rather, it is much more likely that firms are impacted by overhang only after crossing some threshold.

The second empirical measure I use attempts to account for this nonlinearity. In doing so, I take advantage of the richness of the project-level data extracted from the NI 43-101 technical reports. I define indicator variables that take a value of 1 if a firm has existing liabilities - traditional debt, SB, or EB - that exceed the potential value created by the new mineral project. For example, if SB exceeds the estimated NPV of a potential mining project, $\mathbb{1}_{\mathrm{SB} \geq \mathrm{NPV}}=1$. Ultimately, this measure is also imperfect. While it exactly identifies the wedge

${ }^{18}$ See Appendix Table A1 for the details of this ratio. 
in his baseline model, Myers (1977) provides a generalization of the problem for firms that hold more than one asset. In this model, the investment decision is slightly more complicated as the firm compares the NPV of the project $(\Delta V(s)-I(s)$ in Myers' notation) against the capital gain to bondholders if the option is exercised $\left(\Delta V_{D}(s)\right)$. In this framework, using the entire liability $(P)$ assumes the bondholders would get nothing if the firm does not exercise the option. This is unlikely the case for firms with assets in place. However, using the entire liability allows me to avoid making assumptions about asset allocations in bankruptcy. It also represents a necessary (but insufficient) condition for firms to be exposed to overhang (i.e., it must be the case that $\Delta V_{D}(s) \leq P$ ).

\subsection{Data and Summary Statistics}

The vast majority of mine-level data used in this paper are contained in public company filings. Extensive mine-level information is disclosed in regularly filed reports such as the Management Discussion and Analysis (MD\&A) report. The NI 43-101 technical reports also contain detailed data on a company's mineral projects. A mining research firm called Mining Intelligence aggregates the information in these filings and provided me a database of nearly 800 publicly traded Canadian mining firms owning over 3,600 mining projects worldwide during my sample period of 1990-2016. ${ }^{19}$ The data includes historical mine status and ownership, mine type and location, cost of acquisitions, and information extracted from the NI 43-101 technical reports on feasibility. I supplement the data provided by Mining Intelligence with hand-collected estimates of a mine's reclamation liabilities for each permitted mine in my sample. ${ }^{20}$

Table 3 reports summary statistics for the mining projects in my sample. Panel A shows that only $14 \%$ of the 22,379 mine-year observations are in some phase of production. The

\footnotetext{
${ }^{19}$ Mining Intelligence is a division of InfoMine, Inc., a private data intelligence firm that provides data solutions and services to mining companies, suppliers, educators and financiers. The company claims to cover over 14,000 resource extraction companies and 36,000 mining properties worldwide, while collecting data from over 1.8 million publicly filed documents.

${ }^{20}$ Estimates for the reclamation liabilities are most often found in the NI 43-101 technical reports filed prior to production and thus are not updated through time.
} 
vast majority of mining projects in this sample are in the earlier stages of development, with two-thirds of the observations in prospecting, exploration or feasibility. Figure 4 displays these different stages for a typical mining project and highlights important milestones such as when different feasibility studies are often disclosed.

Panel B of Table 3 displays summary statistics for only mines that enter production at some point during the sample. These mines would have been required to submit a bond for their reclamation liabilities to the appropriate local authorities. The average liability of $\$ 27.7$ million and maximum of $\$ 558$ million highlight that reclamation liabilities are nontrivial. Using the self-bonded definition described in Section 3.1, I classify nearly $40 \%$ of the producing mines in my sample as self-bonded. The remainder of Panel B shows the distribution of mines by mine type, primary mineral extracted, and mine location. The mines in my sample are most likely to extract gold and be located in North America, byproducts of using a sample of Canadian mining firms.

Panel C of Table 3 reports the descriptive statistics for the data from the NI 43-101 technical reports and the NPV calculated for the acquisition of mining rights. The mean project (acquisition) NPV is over $\$ 400(\$ 200)$ million while the median is $\$ 172(\$ 89.1)$ million. Due to the high costs of exploratory drilling and the commissioning of the technical reports, it is reasonable to assume that firms only pursue feasibility studies on mining projects that are almost certainly positive NPV. This biases the sample towards including only valuable projects. However, this sample composition allows me to precisely test Myers' (1977) theory that firms will forgo positive NPV projects. Panel $\mathrm{C}$ also highlights the frequency at which firms are exposed to Myers' (1977) wedge. Of the 269 projects, nearly $18 \%$ are owned by a firm with debt liabilities that are greater than the estimated value of the project at the time of disclosure. Far fewer firms have enough exposure to self-bonded reclamation liabilities to surpass the estimated project NPV. However, as I show in Section 4, these liabilities have a large impact on investment decisions.

Table 4 summarizes firm-level variables on reclamation liabilities and the number of 
mining projects in various stages of development for the Canadian mining firms over the sample period of 1990 through 2016. This data is aggregated to the firm-year level from the mine-level data described above. The average firm in my sample with at least one mine in production has just under $\$ 70$ million in reclamation liabilities while the median firm has $\$ 11.9$ million. This suggests that reclamation liabilities, while typically smaller, are of the same order of magnitude as traditional debt liabilities. Table 4 also displays a firm's liability leverage ratios. The maximum values of $S B / M V$ (10.54) and $E B / M V$ (72.41) indicate that certain firms have very high exposure to reclamation liabilities. These statistics match evidence from the U.S. coal mining industry that indicates huge amounts of reclamation liabilities, self-bonded and otherwise, can be concentrated in a small number of firms (Hein et al., 2016).

Finally, Table 4 displays the summary statistics for the firms' accounting variables taken from Compustat-North America. Compared to the typical U.S. industrial sample, the average Canadian mining firm tends to be smaller in terms of book $(\$ 856.8 \mathrm{M})$ and market $(\$ 925 \mathrm{M})$ value of assets, have lower leverage (0.109) and much more variable operating performance. They hold a comparable amount of cash as a percentage of book value of assets (0.243) and have similar growth opportunities (Tobin's $Q=3.3$ ).

\section{Results}

\subsection{Acquisition of Mining Rights}

My first set of empirical tests analyzes firms' propensity to make an initial investment in a new project. For mining firms, the initial investment in a mining project is acquiring the rights to extract the mineral in a specific deposit. I view the option to purchase new mining rights as an auction. Thus, the option immediately expires upon completion of the auction for all but the highest bidder. ${ }^{21}$ This framework allows me to test Myers' (1977)

\footnotetext{
${ }^{21}$ In reality, it is possible the option to purchase new mining rights does not expire immediately. For example, two mining firms may have protracted negotiations regarding the transfer of rights that extends
} 
main empirical prediction that firms will completely forgo investing in positive NPV projects in some states of the world.

Table 5 reports the results of linear probability models (LPMs) in which the dependent variable takes a value of 1 if the firm acquires new mining rights in a given year, and 0 otherwise. $^{22}$ The sample consists of firms located in Canada and listed on the TSX or TSXV exchanges from 1990 through 2016. This first set of tests uses firm-year observations and because I am not analyzing a firm's decision with respect to a specific mineral project, I am constrained to using the first empirical measure, the liability leverage ratio. Each model includes both firm and year fixed effects and I cluster the standard errors at the firm level.

Firm fixed effects present a trade-off between controlling for firm-specific characteristics and perhaps limiting the exogenous variation in the reclamation liabilities. Specifically, when using firm fixed effects, the entire effect is identified by time-series variation within a given firm. Because the estimated reclamation costs are not updated through time, the majority of the variation in my measures of reclamation liabilities comes from opening and closing mines - both arguably endogenous to the decision to invest in new mines. Notwithstanding, I use firm fixed effects in all LPM specifications in my empirical tests for two reasons. First, this does not limit the plausibly exogenous variation in defining liabilities as self-bonded or externally-bonded. If the results were driven completely by opening and closing mines, there should be no difference between self-bonded and externally-bonded reclamation liabilities. Second, the survival analysis in Section 4.2.2 should alleviate this concern completely as all of the identification in those tests comes from the cross-section of reclamation liabilities at the time of the first NPV estimate.

Models (1) through (3) of Table 5 analyze the acquisition of any mining project in my sample - not just those that are NPV positive. Model (1) reports the results without controls, while Model (2) adds covariates for a firm's size (log of book assets), internal capital the life of the option.

${ }^{22}$ I use the LPM as it allows me to include high-dimensional year and firm fixed effects. See Angrist and Pischke (2008) for a discussion on the advantages of the LPM. My results remain largely unchanged when using a logistic or probit model without firm fixed effects. 
constraints (cash), profitability (ROA), growth opportunities (Tobin's $Q$ and firm projects in each stage of development), and lifecycle effects (log of firm age). Because the coefficients in Models (1) and (2) may mask the differences in scale between traditional debt and reclamation liabilities, Model (3) normalizes the three variables of interest by their respective means and standard deviations. ${ }^{23}$ The results suggest that both self-bonded reclamation liabilities and traditional debt have a significant and negative impact on a firm's propensity to acquire new mining rights. In fact, the magnitude of the coefficient for normalized traditional debt (-0.011) in Model (3) is over two times as large as that of self-bonded reclamation liabilities (-0.005). However, because it is unclear whether these mining projects are value increasing, there are several alternative explanations for the negative correlations reported for traditional debt. For example, one such explanation is that debt acts as a governance mechanism, limiting costly overinvestment due to Jensen's (1986) free cash flow problem.

In order to rule out these alternative explanations, Models (4) through (6) restrict the new mining rights to those that look to be NPV positive. I define the NPV of the mining rights as the initial NPV estimate in the NI 43-101 technical reports less the cost paid for the individual mine at acquisition. ${ }^{24}$ Thus, the dependent variable in Models (4) through (6) takes a value of 1 in a year the firm acquires new mining rights in which this NPV is positive, and 0 otherwise.

The inference from these models differs substantially from the first two. For example, in Model (6), the coefficient on the normalized $S B / M V$ remains similar in magnitude at -0.004 and significant at the $1 \%$ level. The normalized coefficient on the market debt leverage ratio, in contrast, drops to -0.003 and is not significant at conventional levels. The results in Models (4) through (6) support Myers' (1977) empirical prediction that firms with existing

\footnotetext{
${ }^{23}$ Thus, in Model (3), $S B / M V$ (normalized) $=(S B / M V-\overline{S B / M V}) / \sigma_{S B / M V}$, and so on. Model (6) similarly normalizes the coefficients for traditional debt and reclamation liabilities. I thank Erik Gilje for this suggestion.

${ }^{24}$ This mining rights NPV measure is noisy as individual mines are often sold in package deals as assets in the sale of a mining operator and it is difficult to assess the value of the mine without the operator's capital assets. However, in using the entire acquisition cost, once again I'm biasing the sample toward the more valuable projects. I exclude sales of mining operators that own more than one mining project. All acquisitions of projects with no NI 43-101 technical reports are defined as NPV $=0$ by default.
} 
obligations will forgo positive NPV growth options in some states of the world, however only for firms with self-bonded reclamation liabilities.

The costs of this investment distortion are non-trivial. Using the coefficient of -0.024 from Model (5) and a baseline acquisition rate of 5.7\% for positive NPV mining rights, a one standard deviation increase in $S B / M V$ is associated with a $(-0.024 \times 0.281) / 0.057=11.8 \%$ decrease in the likelihood of acquiring rights for firms with at least one producing mine. This amounts to an expected $-0.118 \times 0.057 \times 89.1=\$ 0.601$ million loss in value each year the firm maintains high exposure to self-bonded reclamation liabilities. Given the average reclamation liability in my sample is held for 20 years, the present value of these annual costs is $\$ 6.13$ million, or $2.23 \%$ of market value for the median producing firm. ${ }^{25}$ Overall, the results in Table 5 highlight that (1) overhang imposes meaningful costs, and (2) contracting mechanisms allow firms with traditional debt liabilities to avoid these costs, at least ex post. Ultimately, the costs imposed by mine reclamation liabilities offer an upperbound estimate the shadow costs of debt overhang, or the contracting costs firms pay ex ante to avoid distortions created by traditional debt.

\subsection{Mining Projects as Real Options}

Section 4.1 analyzed the impact of a mining firm's liabilities on its propensity to acquire new NPV positive mining rights in an auction framework in which the option to invest expires. Once a firm acquires the rights to mine a particular deposit, however, it has the exclusive right to extract the mineral for a considerable time period. The firm can choose to immediately make capital and infrastructure investments, or the firm can choose to delay construction until a future date. Thus, these existing mining projects represent real options for the firm.

\footnotetext{
${ }^{25}$ These calculations use the median NPV of $\$ 89.1$ million for the mining rights, a market value of $\$ 274.3$ million (median for firms with at least one producing mine), a standard deviation of 0.281 for $S B / M V$ (standard deviation of $S B / M V$ for firms with at least one producing mine) and the median discount rate of 7.5\%. I use the numbers from the subsample of firms with at least one producing mine because firms need to have producing mines in order to be exposed to reclamation liabilities.
} 
Mello and Parsons (1992) and Mauer and Ott (2000) model debt overhang in a real options framework in which the firm's growth option does not simply expire. Both studies, using resource extraction for the setting of their contingent claim models, make similar empirical predictions - mainly the agency cost of debt overhang arises from suboptimal operating decisions. In particular, Mello and Parsons (1992) show that firms will delay opening (or reopening) a mine past the optimal trigger point when mineral prices are low. Similarly, Mauer and Ott (2000) find that firms will delay exercising the option to expand mining operations past the point which maximizes firm value.

In this section, I further utilize the data in the NI 43-101 technical reports to study these predictions. Specifically, I analyze the impact that liabilities have on firms' decision to start construction on positive NPV mining projects. The NI 43-101 technical reports allow me to use detailed data on project specifics in an attempt to control for the optimal trigger point. These controls include the NPV and capital costs associated with the mining project, the expected life of the mine, the primary mineral price, futures prices and implied volatility, among other things. Additionally, these data allow me to use the second empirical measure, which arguably does a better job classifying firms exposed to overhang.

The sample in this section is slightly different from the sample used in the previous section. While the analysis uses the same Canadian mining firms listed on the TSX or TSXV, it uses project-year observations rather than firm-year observations. Thus the sample uses annual data from the time a mineral project is estimated to have a positive NPV value (time $t=0)$ until either the firm begins construction on the project or the sample period ends in 2016. The first year in which NPV estimates were provided in technical reports was 2003, creating a sample of over 800 project-year observations, covering almost 180 firms and over 200 mining projects from 2003 through 2016. 


\subsubsection{Linear Probability Model}

Table 6 displays the results using a linear probability model in which the dependent variable takes a value of 1 if the project starts construction and 0 otherwise. ${ }^{26}$ Once again, the models include year and firm fixed effects in the baseline specification, with robust standard errors clustered at the firm level. ${ }^{27}$ Panel A continues to use the liability leverage ratios. Model (1) presents the results without additional control variables. Models (2) through (5) in Table 6, Panel A, add a host of control variables. These covariates are meant to control for factors in a firm's decision to optimally exercise its real option to construct the mine. For example, Model (2) adds the standard accounting control variables that were used in Table 5, as well as project level controls for the NPV, capital costs, expected mine life, and number of projects in each developmental stage. Models (2) through (5) also attempt to control for a firm's investment opportunity set. Specifically, Model (2) controls for the total NPV of a firm's alternative projects and whether or not the firm begins construction on one of those alternative projects. Model (3) adds a control for the annual percentage change in the mineral price of the primary mineral to be extracted from the mine, Model (4) controls for the 12-month futures price, and Model (5) adds the implied volatility from historical 1-month, at the money, put-call straddles for the primary commodity.

Consistent with the results from Section 4.1, each model in Panel (A) suggests that only self-bonded reclamation liabilities have a significant impact on firms' investment decisions. The coefficients on market leverage and externally-bonded reclamation liabilities are insignificant. The economic magnitude of the overhang effect is large, as Model (3) implies a one standard deviation increase in $S B / M V$ leads to nearly a $25 \%$ decrease in the likelihood (relative to the baseline likelihood) a firm decides to begin construction on a positive NPV mining project in that year. These results are seemingly inconsistent with Gilje et al. (2019), who

\footnotetext{
${ }^{26}$ There is an additional advantage to using the LPM with indicator variables as Angrist and Pischke (2008) point out that models with categorical regressors do not satisfy the assumptions of the logistic or probit model as they are not continuous.

${ }^{27}$ Internet Appendix Table IA5 examines the robustness of Table 6 to the inclusion of alternative fixed effects, such as location, mine type, and primary mineral by year.
} 
find that highly levered oil and gas firms accelerate well completion and start oil production early in order to enhance collateral values and improve renegotiation positioning. However, unlike in the oil and gas industry, there is little reason to believe that the collateral value of a mine is markedly different immediately after starting production, which erodes any incentive for mining firms to push forward investment.

Panel B of Table 6 switches to the second empirical measure - an indicator that equals 1 if the liability exceeds the estimated value of the mineral project and 0 otherwise. Once again, Model (1) examines the impact of the firm's liability on its propensity to begin construction without additional control variables, and the final four models repeat the analyses in Panel A with control variables that are firm-, project-, or mineral-specific and attempt to control for a firm's optimal trigger point. In each model, the coefficient on self-bonded reclamation liabilities is negative and significant while those on traditional debt and externally-bonded reclamation liabilities are near zero and insignificant. For example, the coefficient on Myers' wedge for self-bonded reclamation liabilities in Model (2) is -0.264 and is significant at the $5 \%$ level. This suggests firms with self-bonded reclamation liabilities that exceed the NPV of a mining project are over $26 \%$ less likely to begin construction on the mine in that year than otherwise similar firms.

A potential alternative explanation for the results in Table 6 is that a firm's existing self-bonded reclamation liabilities make it politically difficult for the firm to obtain permits for new mining projects. This explanation would be consistent with the negative relationship between the firm's liabilities and investment in new projects but has a very different interpretation than debt overhang. Internet Appendix Table IA6 addresses this concern by using the fact that many projects have a time gap between the permitting stage and the construction stage. These results show there is no discernible impact of a firm's self-bonding reclamation liabilities on the likelihood the firm obtains new permits.

Overall, the results in Table 6 are consistent with the predictions in Mello and Parsons (1992) and Mauer and Ott (2000) and suggest firm liabilities do impact a firm's decision to 
trigger the real option. However, as with the results in Table 5, this impact is concentrated in liabilities in which the contracting costs are high. In particular, a firm's ability to shorten the maturity of its debt or renegotiate it ex post limits the costs of the overhang problem. Further, the stark difference between self-bonded and externally-bonded reclamation liabilities in these tests offers support for the efficacy of secured obligations in mitigating overhang.

\subsubsection{Survival Analysis}

A second way to examine the effect of a firm's liabilities on its propensity to begin or delay construction is with survival analysis, which in this case, offers two advantages. First, survival analysis allows me to more directly test the empirical predictions in Mello and Parsons (1992) and Mauer and Ott (2000) that firms will delay the exercise of the real option. Additionally, I am able to roughly calculate an average delay imposed by a firm's liabilities. Second, survival analysis allows me to avoid the issue created by using firm fixed effects in the linear probability models. In particular, the variation in the Cox regressions comes from cross-sectional differences in firms' reclamation liabilities at the time of the initial NPV estimate, which is presumably a very similar point in development for each mine. To make this concrete, the liability leverage ratios and indicator variables are fixed at the time the NPV is estimated. Thus, the overhang measures are time-invariant across all observations for a specific project, from the point the NPV is estimated to the end of the sample in 2016, or when the event (construction) occurs, whichever comes first.

Figure 5 displays Kaplan-Meier nonparametric survivor functions for each of the three indicator variables identifying Myers' wedge. Consistent with earlier results, the delay for projects in which self-bonded reclamation liabilities exceed the estimated NPV is stark, while the survivor functions for externally-bonded reclamation liabilities and traditional debt show no discernible differences between projects in which the liabilities exceed the NPV and those 
that it does not. ${ }^{28}$ It is possible, however, that the nonparametric tests do not adequately account for factors relating to the optimal exercise date. Table 7 presents the results from Cox exponential proportional hazard regressions. ${ }^{29}$ Each model includes year and primary mineral fixed effects. ${ }^{30}$

Panel A of Table 7 uses liability leverage ratios, while Panel B uses the indicator for Myers' wedge. Model (1) in Panel A displays the hazard ratios for the liability leverage ratios without additional control variables. The hazard ratio for $S B / M V$ is 0.378 and is significant at the $10 \%$ level. The hazard ratio for $E B / M V$ is also well under 1 , but not significant at conventional levels. Finally, the hazard ratio for the market debt leverage ratio is very close to 1 and is insignificant, suggesting that a firm's traditional debt obligations are unrelated to its decision to exercise the real option.

Models (2) through (5) add the same additional control variables in the same progression as Table 6. The estimated project NPV, capital costs, and mine life are included as static covariates, while the rest are time-varying. Models (2) through (5) report results similar to those in Model (1) in that both self-bonded and externally-bonded reclamation liabilities seem to impact a firm's exercise decision. The main difference in these models is the hazard ratio for self-bonded reclamation liabilities is not significant at conventional levels. The biggest loss of significance happens when adding mineral-specific time-varying coefficients to the Cox models. This could reflect that when better controlling for factors that influence a firm's optimal trigger point, reclamation liabilities lose explanatory power. Alternatively, it could be the case that the time-varying coefficients make identifying true exposure to overhang, a tail event, more difficult for the liability leverage ratios.

\footnotetext{
${ }^{28}$ Further, the observed survivor functions for externally-bonded reclamation liabilities cross, a violation of the proportional hazard assumption.

${ }^{29}$ In unreported tests, I verify that the results are not sensitive to the assumed exponential proportional hazards distribution and remain qualitatively (and quantitatively) similar for the Weibull and Gompertz proportional hazards distributions.

${ }^{30}$ Firm fixed-effects are excluded from the Cox regressions in exchange for primary mineral fixed effects. Just as Kalbfleisch and Sprott (1970) find that logistic and probit models suffer from "incidental parameter bias" when using a large number of parameters, Allison (2002) uses simulations to show this same bias is nearly as severe in Cox regressions.
} 
Panel B of Table 7 displays the results using indicators for Myers' wedge with the same progression of static and time-varying control variables. The hazard ratios for self-bonded reclamation liabilities range between 0.338 and 0.478 , and in contrast to Panel $\mathrm{A}$, remain significant at the $5 \%$ level when including the additional control variables. The hazard ratio of 0.470 in Model (5) suggests that projects in which the NPV is subsumed by a firm's existing self-bonded reclamation liabilities will construct less than half as often as comparable projects at any point in time. This provides support for the argument that the linear measure for overhang struggles to properly identify when firms should be exposed to overhang. Again consistent with earlier results, externally-bonded reclamation liabilities and traditional debt do not impact the timing of the construction decision, suggesting that overhang is an important ex post concern only for liabilities that have high contracting costs. ${ }^{31}$ These results provide direct support for the empirical predictions in Mello and Parsons (1992) and Mauer and Ott (2000).

The costs of the delay imposed by reclamation liabilities are significant. I use a back of the envelope calculation to approximate the delay induced by self-bonded reclamation liabilities. Specifically, I calculate the difference in the survival function between $\mathbb{1}_{\mathrm{SB} \geq \mathrm{NPV}}=1$ and $\mathbb{1}_{\mathrm{SB} \geq \mathrm{NPV}}=0$ at each percentile of mining projects beginning construction. Firm-project pairs in which self-bonded reclamation liabilities exceed the NPV begin construction, on average, 1.9 years later than otherwise similar pairs. For the median project constructing nearly two years later, the new NPV is $172 / 1.075^{1.9}=\$ 149.9$ million, which represents a time-valueof-money loss of $\$ 22.1$ million. Because the baseline likelihood of starting construction on a positive NPV mining project is $5.01 \%$, firms with large self-bond reclamation liabilities face an expected loss each year of $\$ 1.1$ million. The present value of holding this liability for 20 years (typical life of mines in my sample) is $\$ 11.28$ million or $4.11 \%$ of market value for the median producing firm.

\footnotetext{
${ }^{31}$ Even for liabilities with high contracting costs, other market mechanisms may arise to mitigate the costs of overhang. For example, Internet Appendix Table IA7 shows that firms with high self-bonded reclamation liabilities attempt to sell positive NPV projects more often than otherwise similar firms.
} 


\section{Robustness and Extensions}

\subsection{Endogeneity Concerns}

Changes in state-, province- and country-level mining regulations provide plausibly exogenous variation in a firm's reclamation liabilities. There are, however, three main endogeneity concerns with this identification strategy. First, the passage of self-bonding regulations may be influenced by the political economy or specific firms that lobbied for or otherwise motivated the laws (e.g., see Karpoff and Wittry (2018)). Second, firms choose where and when to purchase new mining rights and which mining projects to permit. Finally, even in jurisdictions in which self-bonding is allowed, firms retain the option to externally bond. This section explores the potential severity and impact of each of these concerns.

Unfortunately, documentation on the political economy of mining reforms around the world is quite limited, with the exception of the U.S. Surface Mining Coal Regulation Act (SMCRA) of 1977 and related individual state-level coal regulations. Admittedly, Edgcomb (1983) writes that disproportionate industry influence in coal mining within state political circles fostered lax mining restrictions in general, including self-bonding provisions. However, there is little evidence of individual firms themselves lobbying for self-bonding provisions or fighting new restrictions. For example, according to Open Secret's database on lobbying in the U.S. dating back to 1998, only Peabody Energy has disclosed lobbying activity related to self-bonding policies. Further, of thirteen opposing comments on a 2016 petition filed by WildEarth Guardians seeking heightened self-bonding restrictions in the coal industry, only two were by mining companies: Peabody Energy, and Murray Energy Corporation. ${ }^{32}$ The remaining eleven came from state governments, state- and national-level agencies, and non-profits associated with the mining industry (Mayhall, 2018).

There is also reason to believe state regulators acted on behalf of the state as a whole,

\footnotetext{
${ }^{32}$ For details of the petition, see https://www.federalregister.gov/d/2016-21440.
} 
rather than simply reacting to industry lobbyists. For example, Edgcomb (1983) also argues that state legislators were very careful to avoid creating the perception of a "regulatory atmosphere" out of fear of driving away potential or existing operators, and more importantly, the supply of local jobs and economic activity they create. Overall, this evidence is inconsistent with the idea that U.S. coal regulations were passed at the behest of specific companies, and is supportive of the assumption that changes in self-bonding provisions are plausibly exogenous to any individual firm (except for Peabody Energy, which is not in my sample).

In the end, however, these anecdotes are not systematic evidence of exogeneity, nor do they directly address the firms in my sample. The Internet Appendix reports results that attempt to address this critique. Specifically, Table IA8 replicates the main results in the paper after excluding all reclamation liabilities for mines in a firm's headquarter province when the firm had already begun operations at the time of the law change. It seems reasonable to assume that this group of reclamation liabilities is most likely to suffer from endogeneity problems stemming from the political economy, as firms almost certainly have the most regulatory influence locally. Further, in my project-level sample, over onethird of the firms operate in their headquarter province and so also have a strong incentive to influence regulation. The results in Table IA8 are very similar to those in the main analysis, and are thus consistent with the assumption that the prevailing political economy is not of first-order importance for changes in bonding regulations.

The second main endogeneity concern is that firms decide which projects in which locations to pursue, as well as when to pursue them. That is, firms can time projects around legislation changes or choose to pursue only projects located in locations with favorable bonding requirements. Under this argument, one might expect to see aggregate investment in new mining rights and permits flow into jurisdictions that allow self-bonding and out of regions that prohibit it. Internet Appendix Table IA9 tests this hypothesis for three sets of firms: (1) all firms in my sample, (2) firms with prior mines in the location of the regulation, 
and (3) firms headquartered in the province of the regulation. The results indicate that, on average, self-bonding provisions do not significantly influence firms' decisions to acquire new rights or start the permitting process in one direction or the other. ${ }^{33}$ The results offer further support that firms with the most incentive (firms with prior mines in the location of regulation) and the most power (firms headquartered in the location of regulation) to influence regulation do not shift investment due to self-bonding provisions.

The final concern is the most difficult to test empirically because I do not observe firms' bonding decisions for my main sample. Though my empirical specification largely circumvents this issue by assuming a firm will always choose self-bonding if it can, it is nearly impossible to rule out the possibility that firms choose both the location of projects and subsequent investment policy due the same underlying unobservable characteristic. For example, it could be the case that poorly governed or poorly managed firms permit projects in locations allowing self-bonding in order to continue funding perks, while simultaneously making poor investment decisions. Thus, the Internet Appendix reports a number of additional tests designed to probe the potential selection effects of firms choosing to self-bond.

Tables IA10 reports the results of tests that attempt to separate the bonding decision maker from the investment decision maker. In particular, I exclude reclamation liabilities in which the mine was bonded and subsequent investment decisions were made under the direction of the same CEO. While, BoardEx coverage isn't perfect for Canadian firms, the results remain very similar to the main results in Tables 5 and 6. A second fundamental assumption I make for the main analysis is that a firm's choice of self-bonding is grandfathered in even after local regulators prohibit its use. That is, I assume firms are not required to switch to external bonding methods at the onset of a new regulation. With the excep-

\footnotetext{
${ }^{33}$ Table IA9 mitigates not only this particular selection concern, but also a confounding variables problem based on geographic clustering. Specifically, if there are location economies, firms may choose to pursue several projects in the same jurisdiction. Then, if the passage of self-bonding provisions is correlated with negative local economic shocks, it could be the case that firms with several mines located in such a jurisdiction will also have high levels of self-bonded reclamation liabilities and will invest less in the future due to the shock, not the amount of their reclamation liabilities. The results in Table IA9 strongly suggest this is not the case.
} 
tion of U.S. Federal Statute 43 C.F.R $\$ 3809$, which explicitly grandfathered self-bonds, the actual prevalence of grandfather provisions is highly uncertain. If the majority of mining reforms did not grandfather self-bonds, this would provide additional plausibly exogenous variation in firms' reclamation liabilities. Thus, Table IA11 flips the grandfathering assumption for all regulation changes outside 43 C.F.R $\S 3809$. The results remain qualitatively and quantitatively similar.

Finally, in Internet Appendix Table IA12, I analyze a small secondary sample of U.S. mining firms that self-report their reclamation liabilities and method of financial assurance in annual reports. The results suggest that, by and large, the use of self-bonds is not driven by observable firm characteristics. Overall, the results and discussion in this section indicate that my results are robust to the most serious of endogeneity concerns.

\subsection{Risky Liabilities}

One of the main assumptions in Myers' (1977) model is that the firm's existing liability is risky debt. Thus it seems that a debt overhang effect should be concentrated in firms with riskier liabilities. As a whole, the energy sector is extremely volatile. For example, S\&P Global Ratings (2019) reports that Energy \& Natural Resource's weighted average default rate from 1981-2018 is over 3\%, placing it just behind Leisure Time/Media for highest

defaulting industry. The fact that mining firms, in general, are prone to default suggests that a large percentage of the firms in my sample do indeed have risky liabilities.

Table 8 considers this prediction from Myers' model more directly. I take two approaches to mitigate the impact of safe cash flows and liabilities on my results. First, I replicate my main results after excluding any firm that receives an investment grade security rating at any point in my sample period. Second, I interact each overhang measure from my main tests with an indicator variable that equals one in the year of, and because a downgrade often lags the precipitating event, the year prior to a security rating downgrade from either S\&P or Moody's. 
After excluding investment grade firms, Models (1), (3), and (5) of Table 8 very closely resemble the main tests using the full sample of firms as the coefficient on self-bonded reclamation liabilities is negative and significant at the $1 \%$ level in each. The point estimates in Models (3) and (5) are slightly larger than those with the full sample, suggesting that the safest firms are mitigating the average effect of overhang from self-bonded reclamation liabilities. Models (2), (4), and (6) indicate that the likelihood for firms with self-bonded reclamation liabilities to acquire new rights or begin construction on NPV positive mining projects is significantly lower in downgrade periods. This effect is quite large. For example, the interaction term in Model (4) is -0.368 , nearly 7 times as large as the average effect of $-0.054 .^{34}$

The results in Table 8 confirm two points. First, the mining industry overall is considerably risky. For example, only a handful of firms earn an investment grade security ratings over any sample period used. Further, while the interaction of self-bonded reclamation liabilities with the downgrade period is negative and significant, self-bonded reclamation liabilities on their own are significantly related to underinvestment. Second, the results are consistent with the hypothesis that overhang is more pronounced for riskier liabilities.

\subsection{Short Maturity Liabilities, Asset Volatility, and Bad Times}

Myers (1977) argues that a capital structure strategy of successive short-maturity liabilities can mitigate overhang related investment distortions. However, as noted by Gertner and Scharfstein (1991) and formalized by Diamond and He (2014), short-maturity debt need not always lead to an amelioration of debt overhang. In particular, Diamond and He (2014) show that for firms with high asset volatility in bad times, short-maturity debt imposes additional overhang distortions stemming from a lower sensitivity to firm value.

Table 9 offers, to the best of my knowledge, the first reduced-form results testing this implication. To proxy for short-maturity liabilities, I use a subset of reclamation obligations

\footnotetext{
${ }^{34}$ Internet Appendix Table IA13 confirms these results using the small secondary sample of U.S. firms and the Shumway distance to default as a proxy for financial distress.
} 
created at least eight years in the past - those with an above median maturity. This group is likely to have a short effective maturity relative to more newly created reclamation liabilities. Consistent with Myers' theory, the coefficient for the self-bonding reclamation liabilities in Model (1) of Table 9 is insignificant. ${ }^{35}$

Table 9 also interacts this group of mature liabilities with annual December values of the S\&P/TSX Global Mining Index (TXGM), which was started in 2007. The interaction terms for both overhang measures (Model (2) and (6)) are positive, though only significant for the indicator variable in Model (6). The positive coefficients on the interaction terms suggests that the overhang problem for shorter effective maturity liabilities is at least marginally worse during relatively bad times.

However, when partitioning the sample by the commodity produced, I find that the entire effect of short-maturity self-bonded reclamation liabilities, both the base level and the interaction with the TXGM, is concentrated in non-gold mining firms. Consistent with the idea that gold is a safe haven during recessions (e.g., see Baur and Lucey (2010)), it is reasonable to assume that gold-producing operators will have lower asset volatility during bad times than producers of other commodities. Thus, my results support the predictions in Diamond and He (2014) that short-maturity debt contracts impose additional overhangrelated costs on high-asset volatility firms.

\subsection{Liabilities and Capital Expenditures}

In a final robustness test, I replicate past results in the literature that have examined the effect of a firm's leverage ratio on various proxies for investment. ${ }^{36}$ In particular, Table 10 focuses on the correlation between a firm's leverage ratios and its capital expenditures, one of the most used proxies. Consistent with the results in Section 4, the coefficient on self-

\footnotetext{
${ }^{35}$ As a referee notes, this group of liabilities may also proxy for different bonding and investment decision makers. Thus, it is plausible that this group of liabilities is relative more free of endogeneity issues. Consistent with this hypothesis, the SB indicator in Model (5) is significant at conventional levels.

${ }^{36}$ E.g., see Cantor (1990), Whited (1992), Opler and Titman (1994), Sharpe (1994), Lang et al. (1996), Aivazian et al. (2005), Ahn et al. (2006), Cai and Zhang (2011), and Chu (2019).
} 
bonded reclamation liabilities is negative and significant at the $1 \%$ level. Market leverage is also negatively correlated with capital expenditures and the effect is concentrated in high growth firms, which is often interpreted as debt overhang. This is despite the evidence in Section 4, using the same sample, that shows traditional debt is unrelated to a firm's investment in positive NPV mining projects.

Overall, Table 10 implies that previous results showing a decrease in proxies for investment (CapEx, etc.) may be identifying a decrease in firms' overall investment opportunity sets or a decrease in negative NPV projects, rather than overhang-related distortions. For example, it could be the case that financial covenants restrict Jensen's (1986) free cash flow problem. Additionally, these results provide some measure of reassurance that the results in Section 4 are not simply due to a unique sample.

\section{Conclusion}

Debt overhang is a clearly modeled inefficiency that plays a central role in capital structure theory. However, contracting and debt composition mechanisms exist that could make debt overhang difficult to identify empirically. In addition, fully identifying the effects of overhang requires observing the firm's opportunity set. To mitigate these identification challenges, I exploit novel data on resource extraction that provides ex ante NPV estimates and firms that carry two major types of liabilities, traditional debt and reclamation liabilities, each with different costs associated with avoiding the overhang problem.

Consistent with debt overhang, I find that firms' investment decisions are significantly affected by the overhang imposed by unsecured mine reclamation liabilities. In particular, firms with such liabilities are more likely to forego the acquisition of new positive NPV mining rights, and to postpone construction in existing positive NPV mining projects than firms without such liabilities.

Firms' traditional debt, in contrast, is unrelated to investment in such positive NPV 
projects, consistent with the proposition that contracting and debt composition mechanisms exist that enable firms to avoid the debt overhang problem. This in true even in a sample in which firms' leverage ratios are negatively correlated with capital expenditures. Together, these results suggest that previous studies which use capital expenditures as a proxy for investment may identify a decrease in the overall opportunity set or even a decrease in negative NPV projects.

My findings imply that traditional debt, by itself, imposes few overhang-related investment distortions. This does not mean, however, that debt overhang is unimportant. Rather, my unique setting highlights exactly how important debt overhang is in capital structure decisions and why such effective solutions have endogenously arisen to mitigate it. Specifically, the overhang imposed by mine reclamation liabilities suggests that the shadow costs of these ex ante solutions for traditional debt could be as large as $6.34 \%$ of firm value. 


\section{References}

Ahn, Seoungpil, David J. Denis, and Diane K. Denis, 2006, Leverage and investment in diversified firms, Journal of Financial Economics 79, 317-337.

Aivazian, Varouj A., and Jeffrey L. Callen, 1980, Corporate leverage and growth, Journal of Financial Economics 8, 379-399.

Aivazian, Varouj A., Ying Ge, and Jiaping Qiu, 2005, The impact of leverage on firm investment: Canadian evidence, Journal of Corporate Finance 11, 277-291.

Akey, Pat, and Ian Appel, 2020, The limits of limited liability: Evidence from industrial pollution, Journal of Finance, forthcoming.

Allison, Paul D., 2002, Bias in fixed effects Cox regressions with dummy variables, Working paper, University of Pennsylvania.

Angrist, Joshua D., and Jörn-Steffen Pischke, 2008, Mostly harmless econometrics: An empiricist's companion, Princeton University Press, Princeton, NJ.

Arena, Matteo, and Brandon Julio, 2015, The effects of securities class action litigation on corporate liquidity and investment policy, Journal of Financial and Quantitative Analysis 50, 251-275.

Barclay, Michael J., Leslie M. Marx, and Clifford W. Smith, Jr., 2003, The joint determination of leverage and maturity, Journal of Corporate Finance 9, 149-167.

Barclay, Michael J., and Clifford W. Smith, Jr., 1995, The maturity structure of corporate debt, Journal of Finance 50, 609-631.

Baur, Dirk G., and Brian M. Lucey, 2010, Is gold a hedge or a safe haven? An analysis of stocks, bonds and gold, The Financial Review 45, 217-229.

Bennett, Benjamin, Todd Milbourn, and Zexi Wang, 2018, Corporate investment under the cloud of litigation, Working paper, The Ohio State University.

Bernstein, Asaf, 2019, Negative home equity and household labor supply, Journal of Finance, forthcoming.

Billett, Matthew T., Tao-Hsien Dolly King, and David C. Mauer, 2007, Growth opportunities and the choice of leverage, debt maturity, and covenants, Journal of Finance 62, 697-730.

Bonogofsky, Alexis, Amanda Jahshan, Hilary Yu, Dan Cohn, and Margie MacDonald, 2015, Undermined promises II, Joint publication by the National Wildlife Federation, the Natural Resources Defense Council, and the Western Organization of Resource Councils.

Bureau of Land Management, 2005, BLM Nevada 3809 reclamation bonding guidelines, Prepared by U.S. Department of the Interior, Washington D.C. 
Cai, Jie, and Zhe Zhang, 2011, Leverage change, debt overhang, and stock prices, Journal of Corporate Finance 17, 391-402.

Cantor, Richard, 1990, Effects of leverage on corporate investment and hiring decisions, Federal Reserve Bank of New York Quarterly Review (Summer), 31-41.

Chang, Xin, Kangkang Fu, Tao Li, Lewis H.K. Tam, and George Wong, 2018, Corporate environmental liabilities and capital structure, Working paper, Nangyang Technological University.

Chelimsky, Eleanor, 1988, Surface mining: Cost and availability of reclamation bonds (Report no. PEMD-88-17), Report to the Chairman, Subcommittee on Environment, Energy, and Natural Resources, Committee on Government Operations, House of Representatives, United States General Accounting Office, Washington, D.C.

Chen, Zhiyao, Jarrad Harford, and Avraham Kamara, 2018, Operating leverage, profitability, and capital structure, Journal of Financial and Quantitative Analysis, forthcoming.

Cheng, Linlin, and Jeffrey G. Skousen, 2017, Comparisons of international mine reclamation bonding systems with recommendations for China, International Journal of Coal Science E Technology 4, 67-79.

Childs, Paul D., David C. Mauer, and Steven H. Ott, 2005, Interactions of corporate financing and investment decisions: The effects of agency conflicts, Journal of Financial Economics $76,667-690$.

Chu, Yongqiang, 2019, Debt renegotiation and debt overhang: Evidence from lender mergers, Journal of Financial and Quantitative Analysis, forthcoming.

Custódio, Cláudia, Miguel A. Gerreira, and Luís Laureano, 2013, Why are US firms using more short-term debt?, Journal of Financial Economics 108, 182-212.

Denes, Matthew, 2017, When do firms risk shift? Evidence from venture capital, Working paper, Carnegie Mellon University.

Diamond, Douglas W., 1991, Debt maturity structure and liquidity risk, Quarterly Journal of Economics 106, 709-737.

Diamond, Douglas W., 1993, Seniority and maturity of debt contracts, Journal of Financial Economics 33, 341-368.

Diamond, Douglas W., and Zhiguo He, 2014, A theory of debt maturity: The long and short of debt overhang, Journal of Finance 69, 719-762.

Edgcomb, John D., 1983, Comment, Cooperative federalism and environmental protection: The surface mining control and reclamation act of 1977, Tulane Law Review 58, 299-341.

Ferguson, Andrew, Alexey Feigin, and Stephen Kean, 2013, Gold mine feasibility study disclosure in Australia: Determinants and implications, Resources Policy 38, 8-17. 
Ferguson, Andrew, and Gabriel Pündrich, 2015, Does industry specialist assurance of nonfinancial information matter to investors?, Auditing: A Journal of Practice 85 Theory 34, $121-146$.

Fox, Kenneth A., 2017, The usefulness of NI 43-101 technical reports for financial analysts, Resources Policy 51, 225-233.

Frank, Murray Z., and Vidhan K. Goyal, 2009, Capital structure decisions: Which factors are reliably important?, Financial Management 38, 1-37.

Gertner, Robert, and David Scharfstein, 1991, A theory of workouts and the effects of reorganization law, Journal of Finance 46, 1189-1222.

Gilje, Erik P., 2016, Do firms engage in risk-shifting? Empirical evidence, Review of Financial Studies 29, 2925-2954.

Gilje, Erik P., Elena Loutskina, and Daniel Murphey, 2019, Drilling and debt, Journal of Finance, forthcoming.

Giroud, Xavier, Holger M. Mueller, Alex Stomper, and Arne Westerkamp, 2012, Snow and leverage, Review of Financial Studies 25, 680-710.

Gorton, William T., 2009, Understanding the reclamation surety relationship before and after operator default, Report to the Rocky Mountain Mineral Law Foundation Special Institute on Mine Closure, Financial Assurance, and Final Reclamation, Westminster, CO.

Guedes, Jose, and Tim Opler, 1996, The determinants of the maturity of corporate debt issues, Journal of Finance 51, 1809-1833.

Hein, Jayni F., Ben Snow, Sean Stefanik, and Lauren Webb, 2016, Self-bonding in an era of coal bankruptcy: Recommendations for reform, Institute for Policy Integrity, NYU School of Law.

Hennessy, Christopher A., 2004, Tobin's Q, debt overhang, and investment, Journal of Finance 59, 1717-1742.

Interstate Mining Compact Commission, 2014, Self-bonding survey.

Jensen, Michael C., 1986, Agency costs of free cash flow, corporate finance, and takeovers, American Economic Review Papers 6 Proceedings 76, 323-329.

Jensen, Michael C., and William H. Meckling, 1976, Theory of the firm: Managerial behavior, agency costs and ownership structure, Journal of Financial Economics 3, 305-360.

Johnson, Shane A., 2003, Debt maturity and the effects of growth opportunities and liquidity risk on leverage, Review of Financial Studies 16, 209-236.

Kalbfleisch, John D., and D.A. Sprott, 1970, Application of likelihood methods to models involving large numbers of parameters, Journal of the Royal Statistical Society 32, 175-208. 
Karpoff, Jonathan M., and Michael D. Wittry, 2018, Institutional and legal context in natural experiments: The case of state antitakeover laws, Journal of Finance 73, 657-714.

Kirschner, Lisa A., and Edward B. Grady, 2003, Mining and the vanishing surety bond market, Natural Resources \&f Environment 17, 152-154, 187-189.

Kuipers, James R., 2000, Hardrock reclamation bonding practices in the Western United States, Report to the National Wildlife Federation, Boulder, CO.

Lang, Larry, Eli Ofek, and René M. Stulz, 1996, Leverage, investment, and firm growth, Journal of Financial Economics 40, 3-29.

Marshall, Brenden, 2017, Facts $\&$ figures of the Canadian mining industry, Prepared by The Mining Association of Canada, Ottawa, ON.

Mauer, David C., and Steven H. Ott, 2000, Agency costs, underinvestment, and optimal capital structure: The effect of growth options to expand, in Michael J. Brennan and Lenos Trigeorgis, eds.: Project Flexibility, Agency, and Competition (Oxford University Press, New York, NY), 151-179.

Mayhall, Taylor, 2018, Reclaiming reclamation: Rule changes proposed to ensure coal companies fund mandatory clean-ups, Minnesota Law Review 107, 1451-1484.

Mella-Barral, Pierre, and William Perraudin, 1997, Strategic debt service, Journal of Finance $52,531-556$.

Mello, Antonio S., and John E. Parsons, 1992, Measuring the agency cost of debt, Journal of Finance 47, 1887-1904.

Melzer, Brian T., 2017, Mortgage debt overhang: Reduced investment by homeowners at risk of default, Journal of Finance 72, 575-612.

Merton, Robert C., 1974, On the pricing of corporate debt: The risk structure of interest rates, Journal of Finance 29, 449-470.

Moyen, Nathalie, 2007, How big is the debt overhang problem?, Journal of Economic Dynamics $\&$ Control 31, 433-472.

Myers, Stewart C., 1977, Determinants of corporate borrowing, Journal of Financial Economics 5, 147-175.

Nazzaro, Robin N., 2005, Hardrock mining: BLM needs to better manage financial assurances to guarantee coverage of reclamation costs (Report no. GAO-05-377), Report to the Ranking Minority Member, Committee on Homeland Security and Governmental Affairs, U.S. Senate, United States Government Accountability Office, Washington D.C.

Nikolaev, Valeri V., 2018, Scope for renegotiation in private debt contracts, Journal of Accounting and Economics 65, 270-301.

Ontario Securities Commission, 2011, Form 43-101F1 Technical Report. 
Opler, Tim C., and Sheridan Titman, 1994, Financial distress and corporate performance, Journal of Finance 49, 1015-1040.

Parrino, Robert, and Michael S. Weisbach, 1999, Measuring investment distortions arising from stockholder-bondholder conflicts, Journal of Financial Economics 53, 3-42.

Pawlina, Grzegorz, 2010, Underinvestment, capital structure, and strategic debt restructuring, Journal of Corporate Finance 16, 679-702.

Rauh, Joshua D., 2006, Investment and financing constraints: Evidence from the funding of corporate pension plans, Journal of Finance 61, 33-71.

Rauh, Joshua D., 2009, Risk shifting versus risk management: Investment policy in corporate pension plans, Review of Financial Studies 22, 2687-2733.

Richer La Flèche, Eirk, ed., 2016, The Mining Law Review, Law Business Research, London, UK.

Richer La Flèche, Erik, David Masse, and Jennifer Honeyman, 2016, Chapter 24: Canada capital markets, in Erik Richer La Flèche ed.: The Mining Law Review 5 (Law Business Research Ltd, London, UK), 264-273.

Roberts, Michael R., 2015, The role of dynamic renegotiation and asymmetric information in financial contracting, Journal of Financial Economics 116, 61-81.

Roberts, Michael R., and Amir Sufi, 2009, Renegotiation of financial contracts: Evidence from private credit agreements, Journal of Financial Economics 93, 159-184.

Saretto, Alessio, and Heather E. Tookes, 2013, Corporate leverage, debt maturity, and credit supply: The role of credit default swaps, Review of Financial Studies 26, 1190-1247.

Sharpe, Steven A., 1991, Credit rationing, concessionary lending, and debt maturity, Journal of Banking and Finance 15, 581-604.

Sharpe, Steven A., 1994, Financial market imperfections, firm leverage, and the cyclicality of employment, American Economic Review 84, 1060-1074.

Socalar, Milton J., 1988, Comments on OSMRE authority to waive or negotiate reclamation fees (Report no. B-229068.4), Report prepared for the Department of the Interior's Office of Surface Mining Reclamation and Enforcement, Comptroller General of the United States, Washington, D.C.

S\&P Global Ratings, 2019, 2018 annual global corporate default and ratio transition study.

Strebulaev, Ilya A., and Baozhong Yang, 2013, The mystery of zero-leverage firms, Journal of Financial Economics 109, 1-23.

Stulz, René M., and Herb Johnson, 1985, An analysis of secured debt, Journal of Financial Economics 14, 501-521. 
Titman, Sheridan, and Sergey Tsyplakov, 2007, A dynamic model of optimal capital structure, Review of Finance 11, 401-451.

Walsh, Dan, 2017, Final Bond Determination, Report prepared for Golden Sunlight Mines, Inc., Montana Department of Environmental Quality, Helena, MT.

Whited, Toni M., 1992, Debt, liquidity constraints and corporate investment: Evidence from panel data, Journal of Finance 47, 1425-1460.

Xu, Qiping, 2017, Kicking maturity down the road: Early refinancing and maturity management in the corporate bond market, Review of Financial Studies 31, 3061-3097. 
Figure 1: Investor reaction to the initial NPV estimation. These figures display daily cumulative abnormal returns (CARs) (Panel A) and daily betas (Panel B) from an event study upon the public release of the feasibility study containing the initial net present value (NPV) estimate. The sample consists of firms listed on the Toronto Stock Exchange (TSX) or Toronto Stock Exchange Venture (TSXV) and located in Canada over the sample period of 2003 to 2016. Panel A graphs daily CARs from 10 days prior to 10 days after the first public release of the NPV. The CARs are generated from a market (CAPM) model. Panel B graphs the daily betas over the same period from the following regression: $\mathrm{CAR}_{t}=\alpha+\beta \mathrm{NPV} /$ Market capitalization $t_{t-1}+\gamma_{i}+\epsilon$, which is similar to the regressions in Table 1, Panel B. Data on firms' daily stock returns are from Datastream and data on project NPV is from Mining Intelligence.

\section{Panel A: Daily CARs}

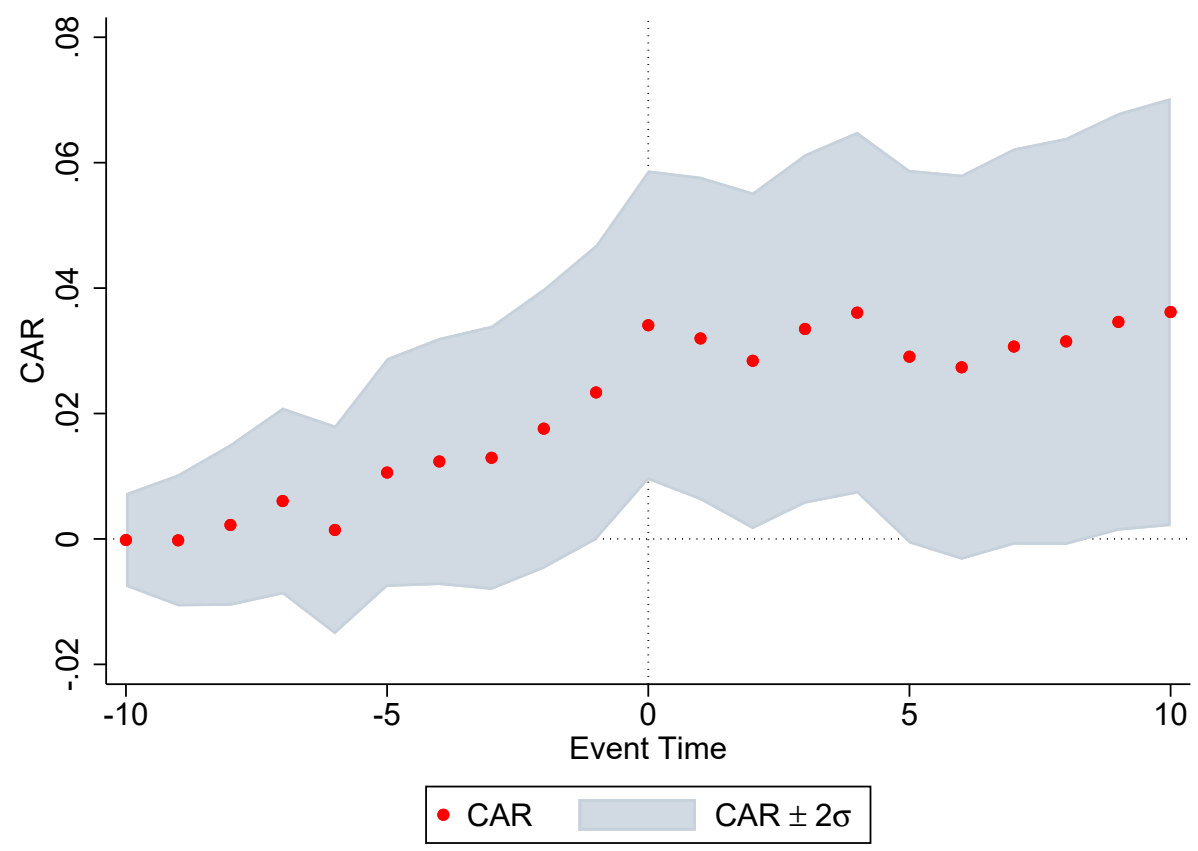

Panel B: Daily Betas

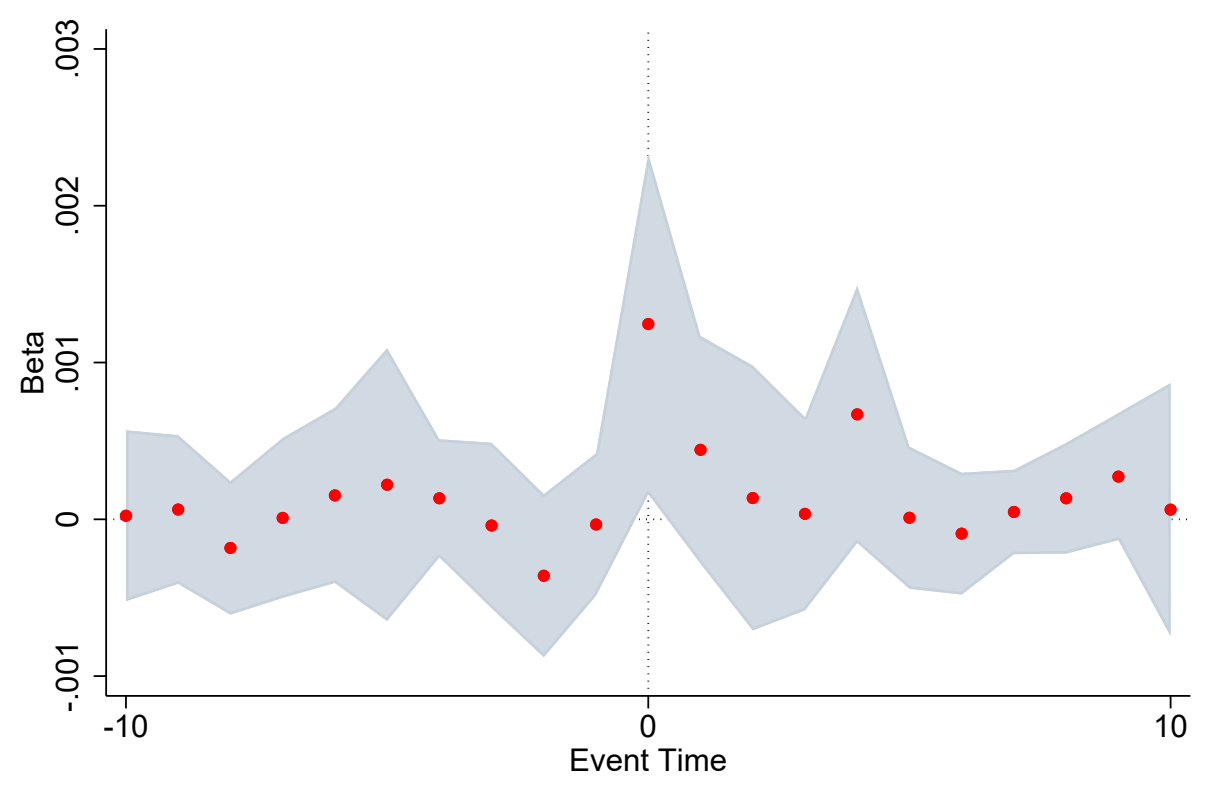

- Beta $\quad$ Beta $\pm 2 \sigma$ 
Figure 2: Forecasted vs. realized annual production. These figures plot forecasted ore (Panel A) and metal in ore (Panel B) production from a project's feasibility study against average annual realized production for projects that have begun production. The normalized root mean square error is the root mean square error divided by the range between the maximum value and the minimum value. Data on firms' forecasted and realized ore and metal in ore production is from Mining Intelligence.

Panel A: Total ore production (Mt)

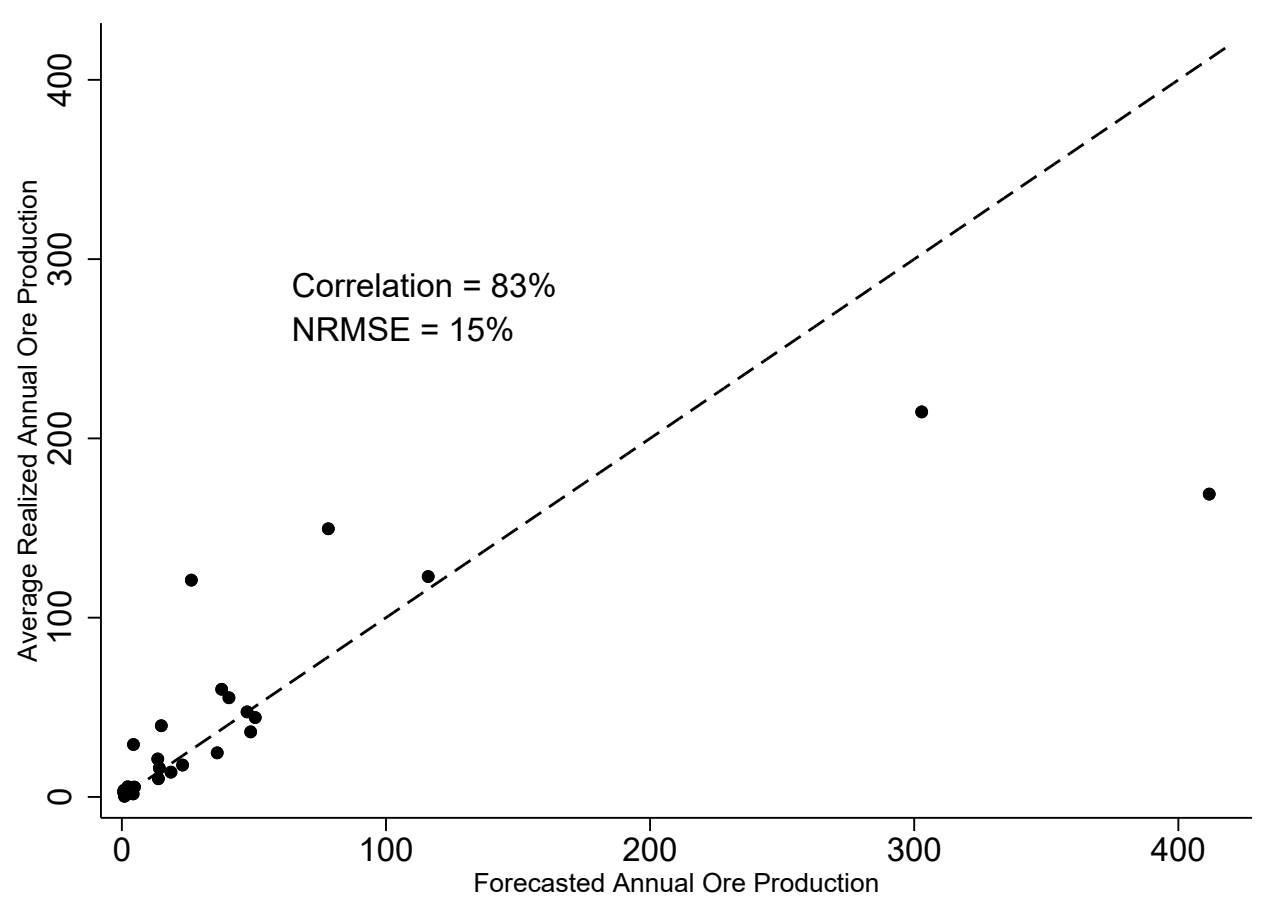

Panel B: Metal in ore production ( $\mathrm{t}$ )

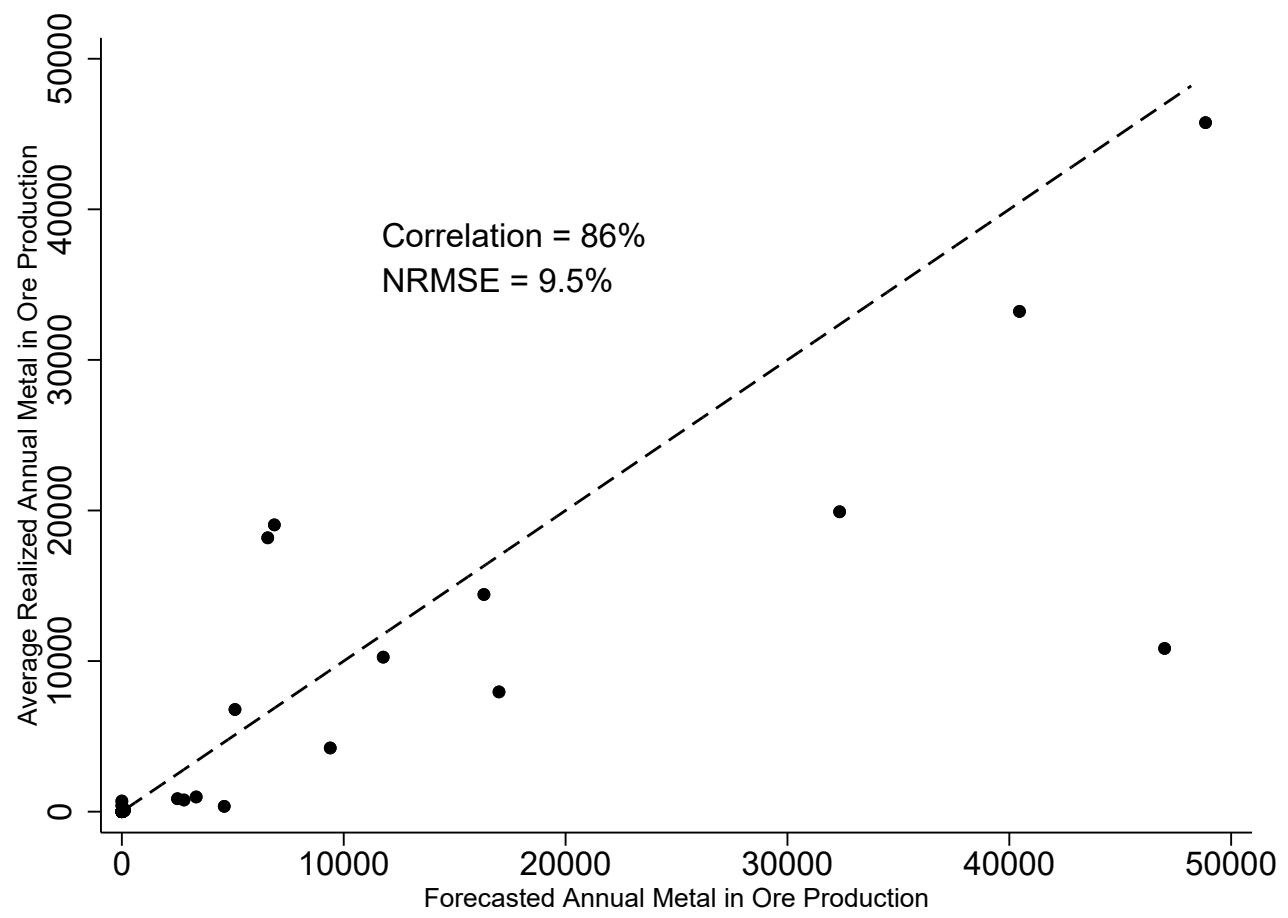


Figure 3: SB vs EB example. This figure displays three coal mines on the border of British Columbia and Alberta, Canada as an example of the specifics of my empirical strategy. The data on estimated reclamation liabilities were hand-collected from firms' public disclosures. Selfbonded and externally-bonded mines are classified using the self-bonding regulations in Table 1 according to the description in Section 3.1.

\section{Highvale Coal Mine, Alberta, CA}

Owner: Transalta

Permitting year: 2007

Estimated reclamation liability: $\$ 42.1 \mathrm{M}$

Alberta self-bonding law: Yes in 1993

Financial assurance definition $=$ Self-bonded

Greenhils Coal Mine, British

\section{Greenhills Coal Mine, British Columbia, CA}

Owner: Teck Resources

Permitting year: 1992

Estimated reclamation liability: $\$ 153.2 \mathrm{M}$

BC self-bonding law: No in 1996

Financial assurance definition $=$ Self-bonded

Elkview Coal Mine, British Columbia, CA

Owner: Teck Resources

Permitting year: 2008

Estimated reclamation liability: $\$ 53.4 \mathrm{M}$

BC self-bonding law: No in 1996

Financial assurance definition = Externally-bonded 
Figure 4: The life cycle of a typical mining project. This figure displays the life cycle of a typical mining project. The source for this figure is KPMG International 2012. This figure also highlights the main milestones at each stage for a mining project. The mines in my sample match very closely with the ranges given for the various stages. The median and mean numbers for mining projects spent in exploration (prospecting and exploration) in my sample are 6 and 7.5 years, respectively. The median and mean numbers for mining projects spent in evaluation (feasibility) in my sample are 5 and 5.2 years, respectively. The median and mean numbers for mining projects spent in development (construction/permitting) in my sample are 3 and 4.75 years, respectively. The median and mean numbers for mining projects spent in production in my sample are 12 and 19.9 years, respectively. Finally, the median and mean numbers for mining projects spent in closure in my sample are 10 and 11.1 years, respectively. It is, however, very difficult to discern when a mining project finishes the closure stage.

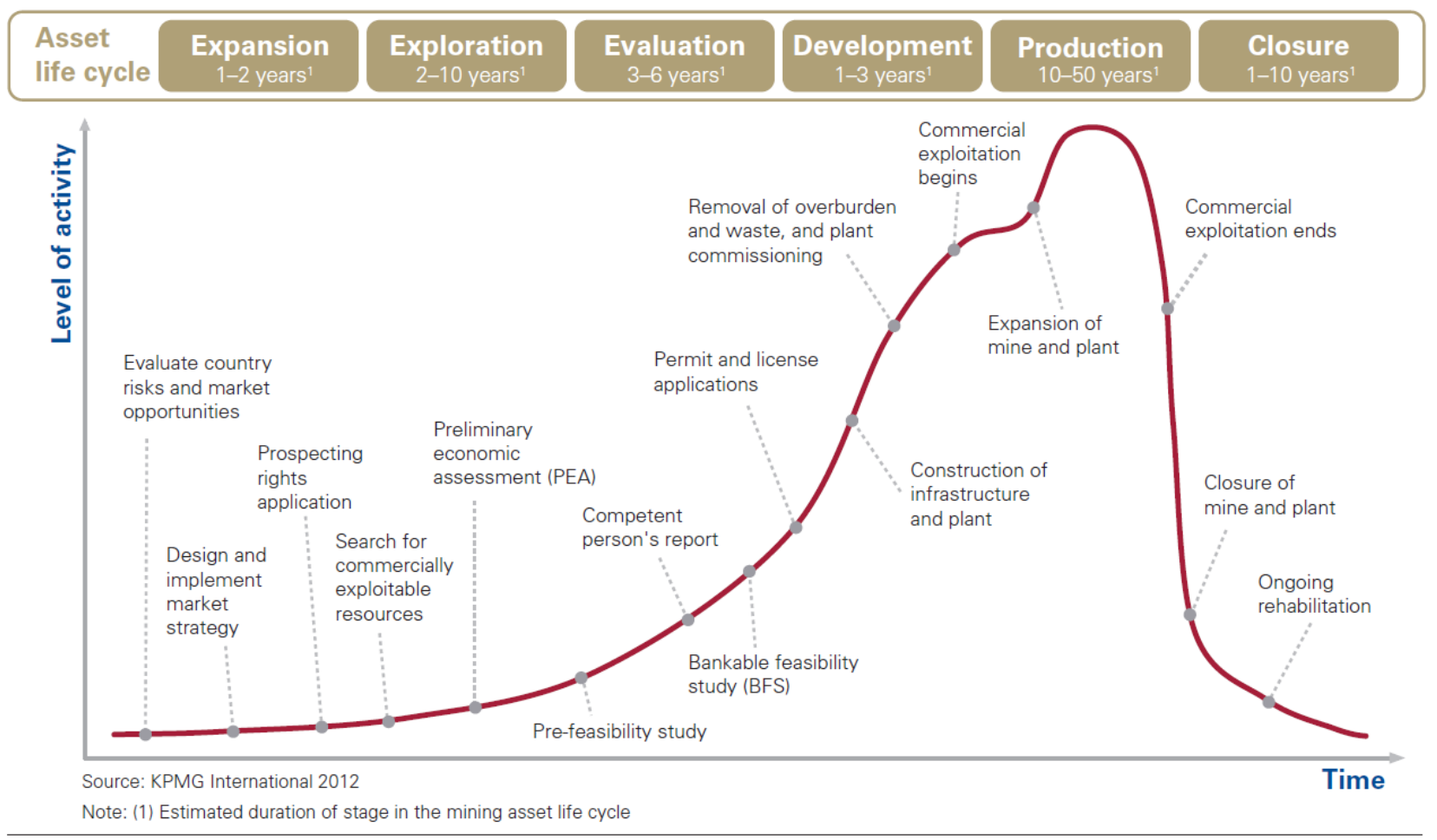


Figure 5: Survival analysis. This figure displays Kaplan-Meier survival functions. The sample is comprised of project-year observations for mining projects from the year the firm publicly discloses the NI 43-101 technical report that includes the initial NPV estimate to the year the firm begins construction on the mine, or the sample period ends, whichever comes first. The sample consists of firms listed on the Toronto Stock Exchange (TSX) or Toronto Stock Exchange Venture (TSXV) and located in Canada over the sample period of 2003 to 2016. A project experiences an "event" when it begins construction. Solid lines represent the observed non-parametric survival functions while dashed lines depict the predicted functions. Each sub-figure is split on whether the liability-self-bonded reclamation liabilities, externally-bonded reclamation liabilities, or traditional debt - exceeds the initial NPV estimate. The data on estimated reclamation liabilities was hand-collected from firms' public disclosures. Self-bonded and externally-bonded mines are classified using the self-bonding regulations in Table 1 according to the description in Section 3.1. A firm's total traditional debt is constructed using data from Compustat - North America and the data on firms' mining projects is provided by Mining Intelligence.
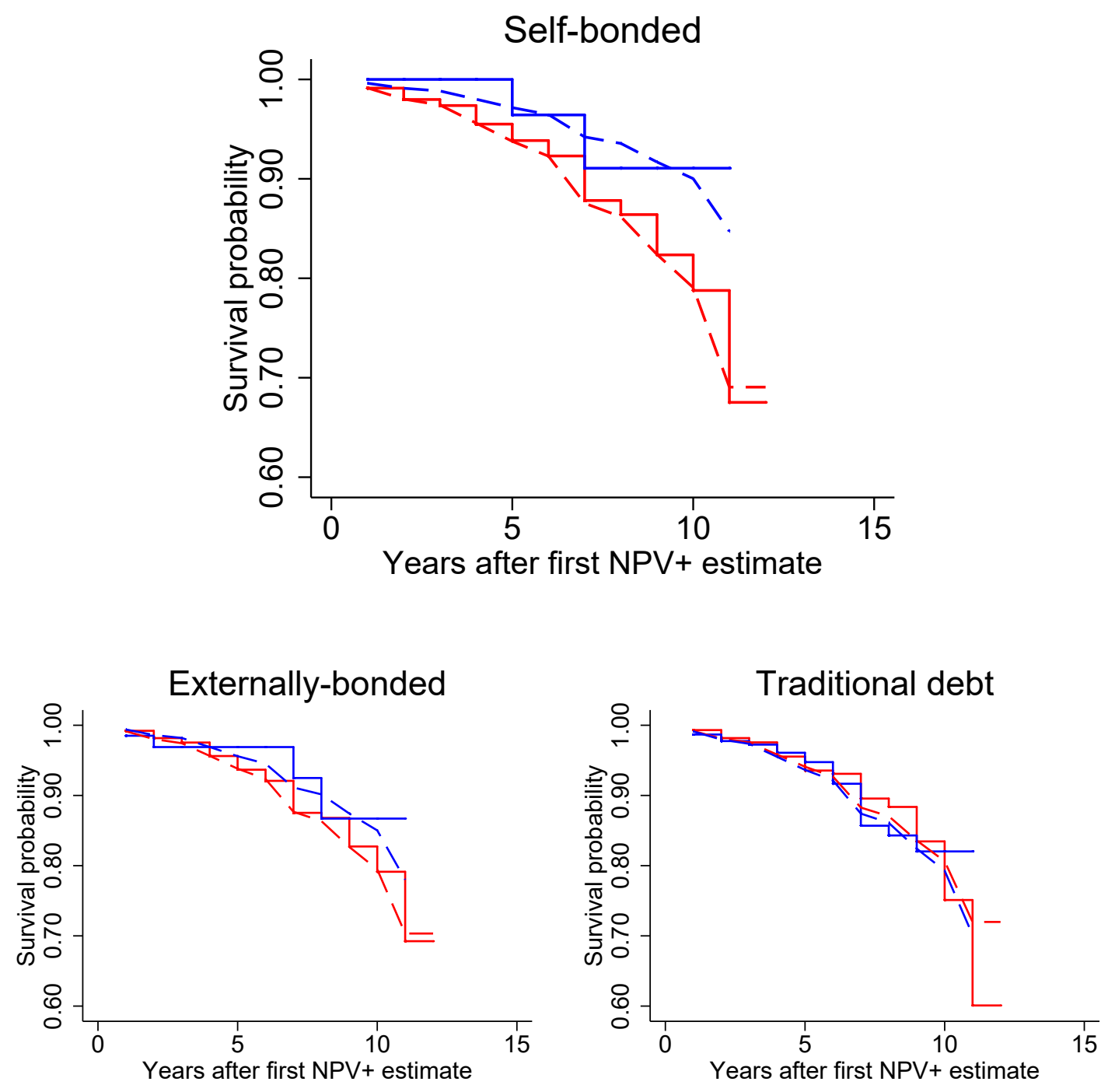

$$
\begin{aligned}
& \text { - Observed: Liability < NPV — Observed: Liability } \geq \text { NPV } \\
& \quad-\quad \text { Predicted: Liability }<\text { NPV } \quad-\quad-\text { Predicted: Liability } \geq \text { NPV }
\end{aligned}
$$


Table 1: Self-bonding mining regulations. This table displays the self-bonding regulations for the United States (panel A) and the rest of the world (panel B). The sources for the mining regulations are the various annotated state statutes and country legislative acts. While this is not an exhaustive list, the regulations listed in this table cover over $90 \%$ of the permitted mines in my sample. For the purposes of this paper, states and countries without a bonding regulation, and those time periods before a law is passed to allow (or disallow) self-bonding, are treated as if they explicitly allow self-bonding.

\begin{tabular}{|c|c|c|c|c|c|c|}
\hline \multirow[b]{2}{*}{ State } & \multicolumn{3}{|l|}{ Coal Mining } & \multicolumn{3}{|c|}{ Hardrock and Metal Mining } \\
\hline & $\begin{array}{l}\text { Federal or } \\
\text { State Statute }\end{array}$ & Year & $\begin{array}{l}\text { Self- } \\
\text { bonding } \\
\text { allowed }\end{array}$ & $\begin{array}{l}\text { Federal or } \\
\text { State Statute }\end{array}$ & Year & $\begin{array}{l}\text { Self- } \\
\text { bonding } \\
\text { allowed }\end{array}$ \\
\hline All & $\begin{array}{l}\text { Surface Mining Control and } \\
\text { Reclamation Act (SMCRA) }\end{array}$ & 1977 & Yes & 43 C.F.R. $\S 3809.555, .571(\mathrm{c})$ & 2001 & No \\
\hline Alabama & ALA. CODE $\S \S 9-16-89(\mathrm{c})$ & 1982 & Yes & ALA. CODE $\S \S 9-16-8$ & 1969 & No \\
\hline Alaska & ALASKA STAT. $\S \S 27.21 .160$ & 1982 & Yes & ALASKA STAT. $\S \S 27.19 .040(\mathrm{e})$ & 1990 & Yes \\
\hline Arizona & & & & ARIZ. REV. STAT. $\$ \S 27-991$ & 1994 & Yes \\
\hline $\begin{array}{l}\text { Arkansas } \\
\text { California }\end{array}$ & ARK. CODE ANN. §§15-58-509 & 1979 & Yes & ARK. CODE ANN. \$\$15-57-317 & $\begin{array}{l}1991 \\
1975\end{array}$ & $\begin{array}{l}\text { Yes } \\
\text { Yes }\end{array}$ \\
\hline Colorado & $\begin{array}{l}\text { COLO. } \\
113(3)\end{array}$ & 1979 & Yes & $\begin{array}{l}\text { COLO. REV. STAT. \$34-32- } \\
117(3) \text { (f) }\end{array}$ & 1977 & Yes \\
\hline Delaware & & & & DEL. CODE ANN. tit. $7 \$ 6115$ & 1953 & Yes \\
\hline Florida & & & & FLA. STAT. ANN. $\S \S 253.571$ & 1969 & Yes \\
\hline Georgia & & & & GA. CODE ANN. $\S \S 12-4-75(3)$ & 1968 & No \\
\hline Hawaii & HAW. REV. STAT. §§182-3 & 1963 & Yes & HAW. REV. STAT. §§182-3 & 1963 & Yes \\
\hline Idaho & & & & $\begin{array}{l}\text { IDAHO CODE } \\
\text { face) }\end{array}$ & 1955 & No \\
\hline & & & & $\begin{array}{l}\text { IDAHO } \\
\text { (dredge) }\end{array} \quad$ CODE $\quad \S 47-1317$ & 1971 & Yes \\
\hline Illinois & $\begin{array}{l}225 \text { ILL. COMP. STAT. } \\
720 / 6.01(\mathrm{~b})\end{array}$ & 1981 & Yes & 225 ILL. COMP. STAT. $715 / 8$ & 1983 & No \\
\hline Indiana & IND. CODE 14-34-7 & 1982 & Yes & IND. CODE 14-36-1-24 & 1995 & Yes \\
\hline Iowa & IOWA CODE $\$ 207.10$ & 1985 & No & IOWA CODE $\$ 208.23$ & 1985 & No \\
\hline Kansas & KAN. STAT. ANN. §§49-615(a) & 1994 & No & KAN. STAT. ANN. §§49-615(a) & 1994 & No \\
\hline Kentucky & $\begin{array}{l}\text { KY. REV. STAT. } \\
\S 350.064(2)\end{array}$ & 1980 & No & & & \\
\hline Louisiana & $\begin{array}{l}\text { LA. REV. } \quad \text { STAT. } \quad \text { ANN. } \\
\S \S 30: 909(\mathrm{c})\end{array}$ & 1978 & No & & & \\
\hline Maine & & & & $\begin{array}{l}\text { ME. REV. STAT. ANN. tit. } 38 \\
\S 490-R R(3)\end{array}$ & 1979 & Yes \\
\hline Maryland & $\begin{array}{l}\text { MD. CODE ANN., ENVIR. } \\
\S \S 15-612\end{array}$ & 1976 & No & $\begin{array}{l}\text { MD. CODE ANN., ENVIR. } \\
\S \S 15-507,15-823\end{array}$ & 1975 & No \\
\hline Michigan & & & & $\begin{array}{ll}\text { MICH. } & \text { COMP. LAWS }\end{array}$ & 1968 & Yes \\
\hline Minnesota & & & & MINN. STAT. $\S \S 93.49$ & 1969 & Yes \\
\hline Mississippi & MISS. CODE ANN. \$\$53-9-31 & 1979 & Yes & MISS. CODE ANN. \$\$53-7-37 & 1977 & Yes \\
\hline Missouri & MO. ANN. STAT. $\S \S 444.950$ & 1982 & Yes & $\begin{array}{l}\text { MO. ANN. STAT. } \$ \S 444.368 \\
\text { (metals) }\end{array}$ & 1989 & Yes \\
\hline & & & & $\begin{array}{l}\text { MO. ANN. STAT. } \$ \S 444.778 \\
\text { (other) }\end{array}$ & 1971 & No \\
\hline $\begin{array}{l}\text { Montana } \\
\text { Nebraska }\end{array}$ & MONT. CODE ANN. §§82-4-223 & 1971 & No & MONT. CODE ANN. §§82-4-338 & 1971 & Yes \\
\hline Nevada & & & & $\begin{array}{l}\text { NEV. REV. } \\
\S \S 519 A .160(4)\end{array}$ & 1989 & Yes \\
\hline New Hampshire & & & & N.H. REV. STAT. §12-E:6 & 1979 & Yes \\
\hline New Mexico & N. M. STAT. ANN. §§69-25A-13 & 1979 & Yes & N. M. STAT. ANN. §§69-36-7(q) & 1994 & No \\
\hline New York & & & & $\begin{array}{l}\text { N.Y. ENVTL. CONSERV. LAW } \\
\S \S 23-2701\end{array}$ & 1976 & Yes \\
\hline North Carolina & & & & N.C. GEN. STAT. $\S \S 74-54$ & 1971 & Yes \\
\hline North Dakota & $\begin{array}{l}\text { N.D. CENT. CODE } \S \S 38-14.1- \\
16.8\end{array}$ & 1979 & Yes & $\begin{array}{l}\text { N.D. CENT. CODE } \\
16.8\end{array}$ & 1979 & Yes \\
\hline Ohio & $\begin{array}{l}\text { OHIO REV. CODE } \\
\S \S 1513.01(\mathrm{~W})\end{array}$ & 2000 & Yes & $\begin{array}{l}\text { OHIO REV. CODE ANN. } \\
\S \S 1514.04\end{array}$ & 2002 & No \\
\hline Oklahoma & OKLA. STAT. tit. $45 \S \S 745.6(\mathrm{e})$ & 1979 & Yes & OKLA. STAT. tit. $45 \S \S 728(\mathrm{e})$ & 1982 & No \\
\hline Oregon & & & & OR. REV. STAT. $\S \S 517.810$ & 1971 & Yes \\
\hline Pennsylvania & 25 PA. CONS. STAT. $\S \S 86.159$ & 1982 & Yes & 25 PA. CONS. STAT. $\S \S 77.222$ & 1990 & No \\
\hline South Carolina & S.C. CODE ANN. $\S \S 48-20-110$ & 1990 & Yes & S.C. CODE ANN. $\S \S 48-20-110$ & 1990 & Yes \\
\hline South Dakota & & & & $\begin{array}{l}\text { S.D. CODIFIED LAWS } \$ \S 45- \\
6 B-23\end{array}$ & 1982 & No \\
\hline Tennessee & TENN. CODE ANN. $\S \S 59-8-408$ & 1987 & No & TENN. CODE ANN. $\S \S 59-8-207$ & 1972 & No \\
\hline Texas & $\begin{array}{l}\text { TEX. NAT. RES. CODE ANN. } \\
\S \S 134.123\end{array}$ & 1995 & Yes & $\begin{array}{l}\text { TEX. NAT. RES. CODE ANN. } \\
\S \S 134.123\end{array}$ & 1995 & Yes \\
\hline Utah & $\begin{array}{l}\text { UTAH CODE ANN. } \$ \S 40-10- \\
15(3)\end{array}$ & 1979 & Yes & $\begin{array}{l}\text { UTAH CODE ANN. } \$ \S 40-8- \\
14(3)\end{array}$ & 1975 & Yes \\
\hline Virginia & VA. CODE ANN. $\S \S 45.1-241$ & 2014 & No & VA. CODE ANN. $\S \S 45.1-183$ & 1968 & No \\
\hline Washington & & & & $\begin{array}{l}\text { WASH. REV. CODE } \\
\S \S 78.56 .110(1) \text { and } 78.44 .087(3)\end{array}$ & 1994 & No \\
\hline West Virginia & W. VA. CODE $\S \S 22-3-11(\mathrm{c})$ & 1987 & Yes & WIS STAT \&\&295.59 and 293.51 & 1973 & $\mathrm{No}$ \\
\hline Wyoming & WYO. STAT. ANN. §§35-11-417 & 1973 & Yes & WYO. STAT. ANN. §§35-11-417 & 1973 & Yes \\
\hline
\end{tabular}


Table 1-Continued

\begin{tabular}{|c|c|c|c|c|c|}
\hline Country & $\begin{array}{l}\text { State or } \\
\text { Province }\end{array}$ & Regulation & Year & $\begin{array}{l}\text { Bonding } \\
\text { Regulation }\end{array}$ & $\begin{array}{l}\text { Self- } \\
\text { bonding } \\
\text { allowed }\end{array}$ \\
\hline Argentina & & 1997 Mining Code & 1997 & No & \\
\hline \multirow[t]{7}{*}{ Australia } & & Mining regulations at the state level & & & \\
\hline & New South Wales & $\begin{array}{l}\text { Protection of the Environment Operations } \\
\text { Act } 1997 \text { No } 156 \text { Part } 9.4\end{array}$ & 1997 & Yes & Yes \\
\hline & Queensland & $\begin{array}{l}\text { Environmental Protection } \\
\text { (EM1010) }\end{array}$ & 1994 & Yes & No \\
\hline & South Australia & Opal Mining Act & 1995 & Yes & Yes \\
\hline & Tasmania & $\begin{array}{l}\text { Mineral Resources Development Act } 1995 \\
\text { Sec } 14,53 \text {, and } 75\end{array}$ & 1995 & Yes & No \\
\hline & Victoria & $\begin{array}{l}\text { Mineral Resources (Sustainable Develop- } \\
\text { ment) Act } 1990 \text { (MR(SD)A) Sec } 78\end{array}$ & 1990 & Yes & No \\
\hline & Western Australia & Mining Act 1978 Sec 126 & 1978 & Yes & Yes \\
\hline Bolivia & & 1997 Mining Code & 1997 & No & \\
\hline Botswana & & Mines and Minerals act of 1999 & 1999 & Yes & Yes \\
\hline Burkina Faso & & $\begin{array}{l}\text { The Mining Code, Article } 12 \text { of Decree No. } \\
2017-068\end{array}$ & 2017 & Yes & No \\
\hline Brazil & & NRM 20 and DN 127 & $\begin{array}{l}2001 \\
2009\end{array}$ & No & \\
\hline \multirow[t]{13}{*}{ Canada } & & Mining regulations at the province level & & & \\
\hline & Alberta & $\begin{array}{l}\text { Conservation and Reclamation Regulation } \\
\text { Sec } 21\end{array}$ & 1993 & Yes & Yes \\
\hline & British Columbia & Bonding Act (RSBC 1996) Chapter 30 & 1996 & Yes & No \\
\hline & Manitoba & $\begin{array}{l}\text { Mine Closure Regulation, } 1999 \text { (Mines and } \\
\text { Mineral Act) }\end{array}$ & 1999 & Yes & Yes \\
\hline & New Brunswick & Mining Act & 1989 & Yes & No \\
\hline & Newfoundland & Mining Act Chapter M-15.10 & 1999 & Yes & No \\
\hline & Northwest Territories & NWT Waters Act & 1992 & Yes & No \\
\hline & Nova Scotia & $\begin{array}{l}\text { Minerals Resources Act S.N.S. 1990, c.18 } \\
\text { Sec } 77\end{array}$ & 1990 & Yes & Yes \\
\hline & Nunavut & Nunavut Water Regulations Sec 10.3 & 2013 & Yes & No \\
\hline & Ontario & Ontario Mining Act & 2000 & Yes & Yes \\
\hline & Quebec & Quebec Mining Act & 1998 & Yes & Yes \\
\hline & Saskatchewan & $\begin{array}{l}\text { The Mineral Industry and Environmental } \\
\text { Protection Regulations }\end{array}$ & 1996 & Yes & No \\
\hline & Yukon Territory & Yukon Water Act & 1992 & Yes & Yes \\
\hline Chile & & 1983 Mining Code & 1983 & No & \\
\hline Colombia & & Law No. 685 (The Mining Code) & 2001 & No & \\
\hline Congo & & Law No. 007/2002 (The Mining Code) & 2002 & Yes & No \\
\hline Dominican Republic & & Environmental Law (Law No. 64-00) & 2000 & Yes & No \\
\hline Ethiopia & & $\begin{array}{l}\text { Environmental Protection Authority Es- } \\
\text { tablishment Proclamation No. 9/1995 }\end{array}$ & 1995 & Yes & No \\
\hline Finland & & $\begin{array}{l}\text { Environmental Protection Act Section 43a } \\
(647 / 2011)\end{array}$ & 2011 & Yes & No \\
\hline Ghana & & EPA Act 494 and LI 1652 & 1999 & Yes & No \\
\hline Indonesia & & R.I. Government Regulation No. 78 & 2010 & Yes & No \\
\hline Mali & & The Mining Law & 1999 & No & \\
\hline Mexico & & NOM-141-SEMARNAT-2003 & 2003 & Yes & No \\
\hline Mongolia & & Mongolia Minerals Law & 1997 & Yes & No \\
\hline Panama & & Code of Mineral Resources, Law 13 of 2012 & 2012 & Yes & No \\
\hline Papua New Guinea & & Mining Act of 1992 & 1992 & No & \\
\hline Peru & & $\begin{array}{l}\text { Law No. } 28090 \text {, Law that Rules the Clos- } \\
\text { ing of Mines (Ley que Regula el Cierre de } \\
\text { Minas) }\end{array}$ & 2003 & Yes & No \\
\hline Philippines & & $\begin{array}{l}\text { DENR Administrative Order No. 2010-21 } \\
\text { (Mining Act IRR) }\end{array}$ & 2010 & Yes & No \\
\hline South Africa & & $\begin{array}{l}\text { National Environment Management Act } \\
\text { (NEMA) }\end{array}$ & 1998 & Yes & No \\
\hline Tanzania & & The Mining Act & 2010 & Yes & Yes \\
\hline Turkey & & $\begin{array}{l}\text { Regulation on Reclamation of Lands Dis- } \\
\text { turbed by Mining }\end{array}$ & 2007 & No & \\
\hline Vietnam & & Mineral Law & 1996 & Yes & No \\
\hline Zambia & & $\begin{array}{l}\text { Mines and Minerals Development Act No. } \\
7 \text { of } 2008\end{array}$ & 2008 & Yes & No \\
\hline Zimbabwe & & $\begin{array}{l}\text { Environmental Management Act [Chapter } \\
20: 27 \text { ] }\end{array}$ & 2002 & Yes & No \\
\hline
\end{tabular}


Table 2: Investor reaction to the initial NPV estimation. This table reports the results of linear regression models in which the dependent variables are the cumulative abnormal returns (CARs) from an event study upon the public release of the feasibility study containing the initial net present value (NPV) estimate. The sample consists of firms listed on the Toronto Stock Exchange (TSX) or Toronto Stock Exchange Venture (TSXV) and located in Canada over the sample period of 2003 to 2016. The main independent variable is the initial NPV estimate divided by the market capitalization of the firm on the day prior to the public release of the feasibility study. Models (1) through (3) in both panels calculate the expected returns using the Fama-French 3-factor model and Models (4) through (6) calculate the expected returns using a 5-factor model (FF 3-factor model plus factors for momentum and liquidity). Panel A does not include fixed effects while Panel B includes a fixed effect for the primary mineral to be extracted. Robust standard errors are reported in parentheses. ${ }^{*}, * *$, and ${ }^{* * *}$ denote significance at the $10 \%, 5 \%$, and $1 \%$ level, respectively.

\begin{tabular}{|c|c|c|c|c|c|c|}
\hline \multicolumn{7}{|l|}{ Panel $A$} \\
\hline \multirow[t]{2}{*}{ Dependent variable $=$} & $\mathrm{CAR}[0,1]$ & $\operatorname{CAR}[-1,1]$ & $\mathrm{CAR}[0,5]$ & $\mathrm{CAR}[0,1]$ & $\operatorname{CAR}[-1,1]$ & $\mathrm{CAR}[0,5]$ \\
\hline & $(1)$ & $(2)$ & $(3)$ & (4) & $(5)$ & $(6)$ \\
\hline $\mathrm{NPV}_{\text {/Market capitalization }}$ M $_{t-1}$ & $\begin{array}{c}0.0010^{* * *} \\
(0.0003)\end{array}$ & $\begin{array}{c}0.0008^{* *} \\
(0.0004)\end{array}$ & $\begin{array}{c}0.0012^{* *} \\
(0.0005)\end{array}$ & $\begin{array}{c}0.0009^{* * *} \\
(0.0003)\end{array}$ & $\begin{array}{c}0.0008^{* *} \\
(0.0004)\end{array}$ & $\begin{array}{c}0.0012^{* *} \\
(0.0005)\end{array}$ \\
\hline Constant & $\begin{array}{l}-0.0007 \\
(0.0079)\end{array}$ & $\begin{array}{c}0.0066 \\
(0.0083)\end{array}$ & $\begin{array}{l}-0.0060 \\
(0.0117)\end{array}$ & $\begin{array}{c}0.0002 \\
(0.0079)\end{array}$ & $\begin{array}{c}0.0085 \\
(0.0083)\end{array}$ & $\begin{array}{l}-0.0042 \\
(0.0117)\end{array}$ \\
\hline Model & 3 -factor & 3 -factor & 3 -factor & 5 -factor & 5 -factor & 5 -factor \\
\hline Primary mineral FEs & No & No & No & No & No & No \\
\hline $\begin{array}{l}\text { Observations } \\
R^{2}\end{array}$ & $\begin{array}{c}172 \\
0.050\end{array}$ & $\begin{array}{c}172 \\
0.032\end{array}$ & $\begin{array}{c}172 \\
0.035\end{array}$ & $\begin{array}{c}172 \\
0.047\end{array}$ & $\begin{array}{c}172 \\
0.032\end{array}$ & $\begin{array}{c}172 \\
0.033\end{array}$ \\
\hline \multicolumn{7}{|l|}{ Panel B } \\
\hline \multirow[t]{2}{*}{ Dependent variable $=$} & $\mathrm{CAR}[0,1]$ & $\operatorname{CAR}[-1,1]$ & $\mathrm{CAR}[0,5]$ & $\mathrm{CAR}[0,1]$ & $\operatorname{CAR}[-1,1]$ & $\mathrm{CAR}[0,5]$ \\
\hline & $(1)$ & $(2)$ & $(3)$ & $(4)$ & $(5)$ & $(6)$ \\
\hline NPV/Market capitalization ${ }_{t-1}$ & $\begin{array}{c}0.0014^{* * *} \\
(0.0003)\end{array}$ & $\begin{array}{c}0.0013^{* * *} \\
(0.0002)\end{array}$ & $\begin{array}{c}0.0015^{* * * *} \\
(0.0004)\end{array}$ & $\begin{array}{c}0.0014^{* * *} \\
(0.0003)\end{array}$ & $\begin{array}{c}0.0013^{* * *} \\
(0.0002)\end{array}$ & $\begin{array}{c}0.0014^{* * *} \\
(0.0003)\end{array}$ \\
\hline Constant & $\begin{array}{l}-0.0045 \\
(0.0073)\end{array}$ & $\begin{array}{c}0.0027 \\
(0.0078)\end{array}$ & $\begin{array}{l}-0.0078 \\
(0.0114)\end{array}$ & $\begin{array}{l}-0.0042 \\
(0.0073)\end{array}$ & $\begin{array}{c}0.0041 \\
(0.0078)\end{array}$ & $\begin{array}{l}-0.0061 \\
(0.0113)\end{array}$ \\
\hline Model & 3-factor & 3 -factor & 3-factor & 5 -factor & 5 -factor & 5-factor \\
\hline Primary mineral FEs & Yes & Yes & Yes & Yes & Yes & Yes \\
\hline Observations & 170 & 170 & 170 & 170 & 170 & 170 \\
\hline$R^{2}$ & 0.301 & 0.248 & 0.388 & 0.302 & 0.261 & 0.395 \\
\hline
\end{tabular}


Table 3: Mine-level summary statistics. This table displays summary statistics for mines owned by firms listed on the Toronto Stock Exchange (TSX) or Toronto Stock Exchange Venture (TSXV) and located in Canada during the period 1990 to 2016. Observations in Panel A are at the mine-year level, and observations in Panel B and Panel $\mathrm{C}$ are at the mine-level. Data on firms' mines, including mine status, mine type, primary mineral extracted, mine location, and project-level data on estimated NPV, capital costs, discount rates, and mine life were provided by Mining Intelligence. Other mining data, including estimated reclamation liabilities and the surface area to be reclaimed were hand-collected from firms' public disclosures. Self-bonded mines are classified using the self-bonding regulations in Table 1 according to the description in Section 3.1. All monetary variables are reported in U.S. dollars, using historical exchange rates from OFX when values are reported in other currencies.

\begin{tabular}{|c|c|c|c|c|c|}
\hline \multicolumn{6}{|c|}{ Panel A: All mining projects (mine-year observations) } \\
\hline Variable & Obs. & $\begin{array}{l}\text { Mean/ } \\
\text { Percentage }\end{array}$ & Median & Min & $\operatorname{Max}$ \\
\hline \multicolumn{6}{|l|}{ Mine status (in \%) } \\
\hline Prospect/exploration & 22,379 & 0.623 & & & \\
\hline Feasibility & 22,379 & 0.041 & & & \\
\hline Construction/Permitting & 22,379 & 0.015 & & & \\
\hline Production & 22,379 & 0.142 & & & \\
\hline Closed & 22,379 & 0.027 & & & \\
\hline \multicolumn{6}{|c|}{ Panel B: Permitted mines (mine observations) } \\
\hline Surface area to be reclaimed (in $\mathrm{km}^{2}$ ) & 580 & 106.5 & 42.5 & 0.04 & 2663 \\
\hline Estimated reclamation liabilities (in $\$ \mathrm{Ms}$ ) & 580 & 27.7 & 6.6 & 0 & 558 \\
\hline Self-bonded mines (in \%) & 580 & 0.398 & & & \\
\hline $\begin{array}{l}\text { Estimated self-bonded } \\
\text { reclamation liabilities (in } \$ \mathrm{Ms} \text { ) }\end{array}$ & 188 & 24.2 & 6.5 & 0.0 & 400 \\
\hline \multicolumn{6}{|l|}{ Mine type (in \%) } \\
\hline Open-pit or surface & 580 & 0.553 & & & \\
\hline Underground & 580 & 0.436 & & & \\
\hline \multicolumn{6}{|l|}{ Primary mineral extracted (in \%) } \\
\hline Gold & 580 & 0.478 & & & \\
\hline Copper & 580 & 0.083 & & & \\
\hline Coal & 580 & 0.071 & & & \\
\hline Silver & 580 & 0.045 & & & \\
\hline Zinc & 580 & 0.045 & & & \\
\hline Uranium & 580 & 0.043 & & & \\
\hline Other or combination & 580 & 0.236 & & & \\
\hline \multicolumn{6}{|l|}{ Mine location (in \%) } \\
\hline Canada & 580 & 0.288 & & & \\
\hline United States & 580 & 0.200 & & & \\
\hline Mexico & 580 & 0.112 & & & \\
\hline Australia & 580 & 0.047 & & & \\
\hline Chile & 580 & 0.036 & & & \\
\hline Brazil & 580 & 0.029 & & & \\
\hline Other & 580 & 0.290 & & & \\
\hline
\end{tabular}

(Continued) 
Table 3-Continued

\begin{tabular}{|c|c|c|c|c|c|}
\hline \multicolumn{6}{|c|}{ Panel C: Projects with Estimated NPV (mine observations) } \\
\hline Variable & Obs. & $\begin{array}{l}\text { Mean/ } \\
\text { Percentage }\end{array}$ & Median & Min & Max \\
\hline Initial NPV estimate $(\$ M s)$ & 269 & 402.4 & 172 & -48.9 & 7114.6 \\
\hline Initial capital costs estimate $(\$ M s)$ & 269 & 535.7 & 223 & 1.2 & 7899.0 \\
\hline Discount rate $(\%)$ & 269 & 6.8 & 7.5 & 5 & 15 \\
\hline Estimated mine life (years) & 269 & 14.1 & 11 & 1 & 50 \\
\hline Projects undertaken by $2016(\%)$ & 269 & 0.283 & & & \\
\hline $\mathbb{1}_{\mathrm{SB} \geq \mathrm{NPV}}$ & 269 & 0.043 & 0 & 0 & 1 \\
\hline $\mathbb{1}_{\mathrm{EB} \geq \mathrm{NPV}}$ & 269 & 0.072 & 0 & 0 & 1 \\
\hline $\mathbb{1}_{\mathrm{TD} \geq \mathrm{NPV}}$ & 269 & 0.177 & 0 & 0 & 1 \\
\hline \multicolumn{6}{|l|}{ Acquisition of mining rights } \\
\hline Total acquisition cost $(\$ \mathrm{Ms})$ & 191 & 38.5 & 9.1 & 0.9 & 532.0 \\
\hline NPV of mining rights $(\$ \mathrm{Ms})$ & 191 & 200.6 & 89.1 & -115.8 & 1129.0 \\
\hline \multicolumn{6}{|l|}{ Primary mineral extracted (in \%) } \\
\hline Gold & 269 & 0.442 & & & \\
\hline Copper & 269 & 0.171 & & & \\
\hline Silver & 269 & 0.041 & & & \\
\hline Uranium & 269 & 0.041 & & & \\
\hline Other or combination & 269 & 0.305 & & & \\
\hline \multicolumn{6}{|l|}{ Mine location (in \%) } \\
\hline Canada & 269 & 0.428 & & & \\
\hline United States & 269 & 0.112 & & & \\
\hline Mexico & 269 & 0.112 & & & \\
\hline Peru & 269 & 0.045 & & & \\
\hline Other & 269 & 0.303 & & & \\
\hline
\end{tabular}


Table 4: Firm-level summary statistics. This table reports firm-level summary statistics for firms listed on the Toronto Stock Exchange (TSX) or Toronto Stock Exchange Venture (TSXV) and located in Canada over the sample period of 1990 to 2016. Data on firms' mines, including the number of mining projects, were provided by Mining Intelligence. The data on estimated reclamation liabilities, as well as the surface area to be reclaimed, were hand-collected from firms' public disclosures. $S B / M V$ is the sum of estimated reclamation liabilities of all a firm's producing mines defined as self-bonded divided by the market value of the firm's assets. $E B / M V$ is the sum of estimated reclamation liabilities of all a firm's producing mines defined as externally-bonded (guaranteed with a surety bond, letter of credit, etc.) divided by the market value of the firm's assets. Self-bonded and externally-bonded mines are classified using the self-bonding regulations in Table 1 according to the description in Section 3.1. Accounting data is from Compustat-North America. Variable definitions are located in Appendix A1. All monetary variables are reported in U.S. dollars, using historical exchange rates from OFX when values are reported in other currencies. All ratio variables are winsorized at the $1 \%$ and $99 \%$ levels.

\begin{tabular}{|c|c|c|c|c|c|}
\hline Variable & Obs. & Mean & Median & Min & Max \\
\hline \multicolumn{6}{|l|}{ Mining variables } \\
\hline Estimated reclamation liabilities (in $\$ M s$ ) & 7,986 & 10.2 & 0.0 & 0.3 & 1,609 \\
\hline $\mathrm{SB} / \mathrm{MV}$ & 7,079 & 0.010 & 0.000 & 0.000 & 10.540 \\
\hline $\mathrm{EB} / \mathrm{MV}$ & 7,079 & 0.058 & 0.000 & 0.000 & 72.410 \\
\hline Surface area to be reclaimed $\left(\mathrm{km}^{2}\right)$ & 7,986 & 38.4 & 0.0 & 0.0 & 3,109 \\
\hline Self-bonded surface area $(\%)$ & 7,986 & 0.07 & 0.00 & 0.00 & 1.00 \\
\hline Likelihood of acquiring new mining rights (all) & 7,986 & 0.194 & 0 & 0 & 1 \\
\hline Likelihood of acquiring new mining rights $(\mathrm{NPV}+)$ & 7,986 & 0.037 & 0 & 0 & 1 \\
\hline Prospect/exploration & 7,986 & 1.6 & 0 & 0 & 73 \\
\hline Feasibility & 7,986 & 0.1 & 0 & 0 & 4 \\
\hline Construction/permitting & 7,986 & 0.0 & 0 & 0 & 6 \\
\hline Production & 7,986 & 0.3 & 0 & 0 & 15 \\
\hline Closed & 7,986 & 0.1 & 0 & 0 & 7 \\
\hline \multicolumn{6}{|l|}{ Mining variables (firms with producing mines) } \\
\hline Estimated reclamation liabilities (in $\$ \mathrm{Ms}$ ) & 1,182 & 68.7 & 11.9 & 0.3 & 1,609 \\
\hline $\mathrm{SB} / \mathrm{MV}$ & 1,094 & 0.062 & 0.004 & 0.000 & 10.540 \\
\hline $\mathrm{EB} / \mathrm{MV}$ & 1,094 & 0.373 & 0.009 & 0.000 & 72.410 \\
\hline Surface area to be reclaimed $\left(\mathrm{km}^{2}\right)$ & 1,182 & 259.3 & 87.1 & 0.0 & 3,109 \\
\hline Self-bonded surface area $(\%)$ & 1,182 & 0.48 & 0.34 & 0.00 & 1.00 \\
\hline Likelihood of acquiring new mining rights (all) & 1,094 & 0.265 & 0 & 0 & 1 \\
\hline Likelihood of acquiring new mining rights $(\mathrm{NPV}+)$ & 1,094 & 0.057 & 0 & 0 & 1 \\
\hline Prospect/exploration & 1,094 & 2.9 & 1 & 0 & 73 \\
\hline Feasibility & 1,094 & 0.2 & 0 & 0 & 4 \\
\hline Construction/permitting & 1,094 & 0.2 & 0 & 0 & 6 \\
\hline Production & 1,094 & 2.4 & 1 & 1 & 15 \\
\hline Closed & 1,094 & 0.3 & 0 & 0 & 7 \\
\hline \multicolumn{6}{|l|}{ Accounting variables } \\
\hline Capital expenditures (\% of book assets) & 7,498 & 0.132 & 0.081 & 0.000 & 0.824 \\
\hline Book value of assets (BV) (in $\$ M s$ ) & 7,609 & 856.8 & 21.0 & 0.0 & 76,467 \\
\hline Market value of assets (MV) (in $\$ M$ s) & 7,079 & 925.0 & 23.3 & 0.0 & 61,511 \\
\hline Short-term debt (STD) (in $\$ M s$ ) & 7,601 & 18.1 & 0.0 & 0.0 & 7,338 \\
\hline Long-term debt (LTD) (in $\$ M s$ ) & 7,604 & 155.5 & 0.0 & 0.0 & 13,173 \\
\hline Market leverage (\%) & 7,079 & 0.109 & 0.000 & 0.000 & 0.911 \\
\hline Return on assets (ROA) (\%) & 7,516 & -0.795 & -0.098 & -21.182 & 0.314 \\
\hline Cash (\% of book assets) & 7,603 & 0.243 & 0.134 & 0.000 & 0.988 \\
\hline Tobin's $Q$ & 7,077 & 3.3 & 1.1 & 0.1 & 64.5 \\
\hline Annual stock return (\%) & 6,685 & 0.435 & -0.100 & -0.907 & 11.750 \\
\hline
\end{tabular}


Table 5: Firm liabilities and the likelihood of acquiring the rights to new positive NPV mining projects. This table reports the results of linear probability models in which the dependent variable is the likelihood a firm acquires the rights to a new positive net present value $(\mathrm{NPV}+)$ mining project. The NPV of the mining rights is defined as the value of the NPV estimate in the NI 43-101 technical reports less the cost the acquiring firm paid for the individual mine at acquisition. The sample consists of firms listed on the Toronto Stock Exchange (TSX) or Toronto Stock Exchange Venture (TSXV) and located in Canada over the sample period of 1990 to 2016. $S B / M V$ is the sum of estimated reclamation liabilities of all a firm's producing mines defined as self-bonded divided by the market value of the firm's assets. $E B / M V$ is the sum of estimated reclamation liabilities of all a firm's producing mines defined as externally-bonded (guaranteed with a surety bond, letter of credit, etc.) divided by the market value of the firm's assets. The data on estimated reclamation liabilities were hand-collected from firms' public disclosures. Self-bonded and externally-bonded mines are classified using the self-bonding regulations in Table 1 according to the description in Section 3.1. In Models (3) and (6), $S B / M V, E B / M V$ and market leverage are each normalized by their mean and standard deviation. Accounting variables (defined in Appendix Table A1) are constructed using data from Compustat - North America and the data on firms' mining projects were provide by Mining Intelligence. Robust standard errors, clustered at the firm level, are reported in parentheses. ${ }^{*}, * *$, and ${ }^{* * *}$ denote significance at the $10 \%, 5 \%$, and $1 \%$ level, respectively.

\begin{tabular}{|c|c|c|c|c|c|c|}
\hline \multirow[t]{2}{*}{ Dependent variable $=$} & \multicolumn{3}{|c|}{$\begin{array}{l}\text { Likelihood of acquiring } \\
\text { rights to any project }\end{array}$} & \multicolumn{3}{|c|}{$\begin{array}{l}\text { Likelihood of acquiring } \\
\text { rights to NPV + projects }\end{array}$} \\
\hline & $(1)$ & $(2)$ & $(3)$ & $(4)$ & $(5)$ & $(6)$ \\
\hline $\mathrm{SB} / \mathrm{MV}$ & $-0.030^{* * *}$ & $\begin{array}{c}-0.035^{* *} \\
(0.015)\end{array}$ & & $-0.022^{* * *}$ & $-0.024^{* * *}$ & \\
\hline $\mathrm{EB} / \mathrm{MV}$ & $\begin{array}{c}0.002 \\
(0.003)\end{array}$ & 0.003 & & 0.001 & 0.001 & \\
\hline Market leverage & $\begin{array}{l}-0.046 \\
(0.031)\end{array}$ & $\begin{array}{c}-0.057^{*} \\
(0.032)\end{array}$ & & $\begin{array}{l}-0.014 \\
(0.015)\end{array}$ & $\begin{array}{l}-0.026 \\
(0.016)\end{array}$ & \\
\hline SB/MV (normalized) & & & $\begin{array}{c}-0.005^{* *} \\
(0.002)\end{array}$ & & & $\begin{array}{c}-0.004^{* * *} \\
(0.001)\end{array}$ \\
\hline EB/MV (normalized) & & & $\begin{array}{c}0.005 \\
(0.004)\end{array}$ & & & $\begin{array}{c}0.001 \\
(0.001)\end{array}$ \\
\hline Market leverage (normalized) & & & $\begin{array}{c}-0.011^{*} \\
(0.007)\end{array}$ & & & $\begin{array}{l}-0.003 \\
(0.002)\end{array}$ \\
\hline Log of book assets & & $\begin{array}{c}0.018^{* * *} \\
(0.005)\end{array}$ & $\begin{array}{c}0.018^{* * *} \\
(0.005)\end{array}$ & & $\begin{array}{c}0.003 \\
(0.002)\end{array}$ & $\begin{array}{c}0.003 \\
(0.002)\end{array}$ \\
\hline Cash & & $\begin{array}{c}0.013 \\
(0.023)\end{array}$ & $\begin{array}{c}0.013 \\
(0.023)\end{array}$ & & $\begin{array}{c}0.009 \\
(0.011)\end{array}$ & $\begin{array}{c}0.009 \\
(0.011)\end{array}$ \\
\hline $\mathrm{ROA}$ & & $\begin{array}{c}0.000 \\
(0.002)\end{array}$ & $\begin{array}{c}0.000 \\
(0.002)\end{array}$ & & $\begin{array}{c}0.000 \\
(0.001)\end{array}$ & $\begin{array}{c}0.000 \\
(0.001)\end{array}$ \\
\hline Tobin's $Q$ & & $\begin{array}{l}0.001 \\
(0.001)\end{array}$ & $\begin{array}{c}0.001 \\
(0.001)\end{array}$ & & $\begin{array}{c}0.000 \\
(0.000)\end{array}$ & $\begin{array}{c}0.000 \\
(0.000)\end{array}$ \\
\hline Log of firm age & & $\begin{array}{c}0.001 \\
(0.021)\end{array}$ & $\begin{array}{c}0.001 \\
(0.021)\end{array}$ & & $\begin{array}{c}-0.027^{* *} \\
(0.011)\end{array}$ & $\begin{array}{c}-0.027^{* *} \\
(0.011)\end{array}$ \\
\hline \# of mines in exploration & & $\begin{array}{c}0.026^{* * *} \\
(0.007)\end{array}$ & $\begin{array}{c}0.026^{* * * *} \\
(0.007)\end{array}$ & & $\begin{array}{c}0.001 \\
(0.001)\end{array}$ & $\begin{array}{c}0.001 \\
(0.001)\end{array}$ \\
\hline \# of mines in feasibility & & $\begin{array}{c}0.015 \\
(0.023)\end{array}$ & $\begin{array}{c}0.015 \\
(0.023)\end{array}$ & & $\begin{array}{c}0.013 \\
(0.018)\end{array}$ & $\begin{array}{c}0.013 \\
(0.018)\end{array}$ \\
\hline \# of mines in construction/permitting & & $\begin{array}{c}0.024 \\
(0.030)\end{array}$ & $\begin{array}{c}0.024 \\
(0.030)\end{array}$ & & $\begin{array}{c}0.049^{* * *} \\
(0.019)\end{array}$ & $\begin{array}{c}0.049^{* *} \\
(0.019)\end{array}$ \\
\hline \# of producing mines & & $\begin{array}{c}0.008 \\
(0.016)\end{array}$ & $\begin{array}{c}0.008 \\
(0.016)\end{array}$ & & $\begin{array}{c}0.015^{* *} \\
(0.007)\end{array}$ & $\begin{array}{c}0.015^{* *} \\
(0.007)\end{array}$ \\
\hline \# of closed mines & & $\begin{array}{c}0.024 \\
(0.030)\end{array}$ & $\begin{array}{c}0.024 \\
(0.030)\end{array}$ & & $\begin{array}{c}0.046^{* *} \\
(0.020)\end{array}$ & $\begin{array}{c}0.046^{* *} \\
(0.020)\end{array}$ \\
\hline Aquire mining rights (other) & & & & & & \\
\hline Firm FE & Yes & Yes & Yes & Yes & Yes & Yes \\
\hline Year FE & Yes & Yes & Yes & Yes & Yes & Yes \\
\hline Number of firms & 790 & 775 & 775 & 790 & 775 & 775 \\
\hline Observations & 7,083 & 6,747 & 6,747 & 7,083 & 6,747 & 6,747 \\
\hline$R^{2}$ & 0.275 & 0.301 & 0.301 & 0.128 & 0.151 & 0.151 \\
\hline
\end{tabular}


Table 6: Firm liabilities and the likelihood of beginning construction on positive NPV projects. This table reports the results of linear probability models in which the dependent variable is the likelihood of beginning construction on a positive net present value (NPV+) project. The sample is comprised of project-year observations for mining projects from the year the firm publicly discloses the NI 43-101 technical report that includes the initial NPV estimate to the year the firm begins construction on the mine, or the sample period ends, whichever comes first. The sample consists of firms listed on the Toronto Stock Exchange (TSX) or Toronto Stock Exchange Venture (TSXV) and located in Canada over the sample period of 2003 to 2016. $S B / M V$ is the sum of estimated reclamation liabilities of all of a firm's producing mines defined as self-bonded divided by the market value of the firm's assets. $E B / M V$ is the sum of estimated reclamation liabilities of all of a firm's producing mines defined as externally-bonded (guaranteed with a surety bond, letter of credit, etc.) divided by the market value of the firm's assets. $\mathbb{1}_{\mathrm{SB} \geq \mathrm{NPV}}$ is an indicator variable that equals 1 if the sum of estimated reclamation liabilities of all of a firm's producing mines defined as self-bonded exceeds the initial NPV estimate of the mining project. $\mathbb{1}_{\mathrm{EB}}>\mathrm{NPV}$ is an indicator variable that equals 1 if the sum of estimated reclamation liabilities of all of a firm's producing mines defined as externally-bonded (guaranteed with a surety bond, letter of credit, etc.) exceeds the initial NPV estimate of the mining project. $\mathbb{1}_{\mathrm{TD}} \geq \mathrm{NPV}$ is an indicator variable that equals 1 if the firm's traditional debt exceeds the initial NPV estimate of the mining project. The data on estimated reclamation liabilities were hand-collected from firms' public disclosures. Self-bonded and externally-bonded mines are classified using the self-bonding regulations in Table 1 according to the description in Section 3.1. Accounting variables (defined in Appendix Table A1) are constructed using data from Compustat-North America, the project data were provide by Mining Intelligence and futures data is from Bloomberg. Robust standard errors, clustered at the firm level, are reported in parentheses. ${ }^{*}, * *$, and ${ }^{* * *}$ denote significance at the $10 \%, 5 \%$, and $1 \%$ level, respectively.

\begin{tabular}{|c|c|c|c|c|c|}
\hline \multicolumn{6}{|l|}{ Panel A: Liability ratios } \\
\hline \multirow{2}{*}{ Dependent variable $=$} & \multicolumn{5}{|c|}{ Likelihood of beginning construction on an NPV+ project } \\
\hline & $(1)$ & $(2)$ & $(3)$ & $(4)$ & $(5)$ \\
\hline $\mathrm{SB} / \mathrm{MV}$ & $\begin{array}{c}-0.046 * * * \\
(0.014)\end{array}$ & $\begin{array}{c}-0.054^{* * *} \\
(0.014)\end{array}$ & $\begin{array}{c}-0.058^{* * * *} \\
(0.016)\end{array}$ & $\begin{array}{c}-0.046^{* *} \\
(0.020)\end{array}$ & $\begin{array}{c}-0.119^{* * *} \\
(0.023)\end{array}$ \\
\hline $\mathrm{EB} / \mathrm{MV}$ & $\begin{array}{c}0.020 \\
(0.061)\end{array}$ & $\begin{array}{c}0.003 \\
(0.062)\end{array}$ & $\begin{array}{c}0.021 \\
(0.124)\end{array}$ & $\begin{array}{c}0.004 \\
(0.123)\end{array}$ & $\begin{array}{c}0.112 \\
(0.131)\end{array}$ \\
\hline Market leverage & $\begin{array}{c}0.010 \\
(0.058)\end{array}$ & $\begin{array}{l}-0.007 \\
(0.056)\end{array}$ & $\begin{array}{l}-0.039 \\
(0.057)\end{array}$ & $\begin{array}{l}-0.041 \\
(0.062)\end{array}$ & $\begin{array}{l}-0.067 \\
(0.070)\end{array}$ \\
\hline Log of book assets & & $\begin{array}{c}0.018 \\
(0.014)\end{array}$ & $\begin{array}{c}0.015 \\
(0.015)\end{array}$ & $\begin{array}{c}0.015 \\
(0.016)\end{array}$ & $\begin{array}{c}0.011 \\
(0.019)\end{array}$ \\
\hline Cash & & $\begin{array}{c}0.043 \\
(0.059)\end{array}$ & $\begin{array}{c}0.029 \\
(0.064)\end{array}$ & $\begin{array}{c}0.036 \\
(0.064)\end{array}$ & $\begin{array}{c}0.047 \\
(0.068)\end{array}$ \\
\hline $\mathrm{ROA}$ & & $\begin{array}{l}-0.015 \\
(0.012)\end{array}$ & $\begin{array}{l}-0.016 \\
(0.015)\end{array}$ & $\begin{array}{l}-0.017 \\
(0.015)\end{array}$ & $\begin{array}{l}-0.013 \\
(0.016)\end{array}$ \\
\hline Tobin's $Q$ & & $\begin{array}{c}0.000 \\
(0.005)\end{array}$ & $\begin{array}{l}-0.001 \\
(0.006)\end{array}$ & $\begin{array}{l}-0.002 \\
(0.007)\end{array}$ & $\begin{array}{l}-0.002 \\
(0.008)\end{array}$ \\
\hline Log of firm age & & $\begin{array}{l}-0.055 \\
(0.064)\end{array}$ & $\begin{array}{l}-0.030 \\
(0.072)\end{array}$ & $\begin{array}{l}-0.035 \\
(0.073)\end{array}$ & $\begin{array}{l}-0.013 \\
(0.069)\end{array}$ \\
\hline Project NPV ( $\$ 100 \mathrm{Ms})$ & & $\begin{array}{c}0.014^{* *} \\
(0.007)\end{array}$ & $\begin{array}{l}0.016^{*} \\
(0.008)\end{array}$ & $\begin{array}{l}0.015^{*} \\
(0.008)\end{array}$ & $\begin{array}{l}0.013^{*} \\
(0.007)\end{array}$ \\
\hline Project Capital Costs $(\$ 100 \mathrm{Ms})$ & & $\begin{array}{c}-0.014^{* *} \\
(0.007)\end{array}$ & $\begin{array}{r}-0.013^{*} \\
(0.007)\end{array}$ & $\begin{array}{c}-0.012^{*} \\
(0.006)\end{array}$ & $\begin{array}{c}-0.012^{* *} \\
(0.006)\end{array}$ \\
\hline Expected mine life & & $\begin{array}{l}-0.002 \\
(0.004)\end{array}$ & $\begin{array}{l}-0.002 \\
(0.005)\end{array}$ & $\begin{array}{l}-0.001 \\
(0.007)\end{array}$ & $\begin{array}{l}-0.003 \\
(0.007)\end{array}$ \\
\hline Total NPV of alternative projects $(\$ 100 \mathrm{Ms})$ & & $\begin{array}{l}-0.014 \\
(0.011)\end{array}$ & $\begin{array}{l}-0.012 \\
(0.011)\end{array}$ & $\begin{array}{l}-0.011 \\
(0.011)\end{array}$ & $\begin{array}{l}-0.011 \\
(0.011)\end{array}$ \\
\hline Start alternative NPV + project & & $\begin{array}{l}-0.042 \\
(0.112)\end{array}$ & $\begin{array}{l}-0.035 \\
(0.115)\end{array}$ & $\begin{array}{l}-0.017 \\
(0.116)\end{array}$ & $\begin{array}{l}-0.014 \\
(0.117)\end{array}$ \\
\hline Primary mineral price ( $\%$ ch. $)$ & & & $\begin{array}{l}-0.037 \\
(0.061)\end{array}$ & & \\
\hline Futures price & & & & $\begin{array}{l}0.009 \\
(0.015)\end{array}$ & $\begin{array}{l}-0.006 \\
(0.013)\end{array}$ \\
\hline Options-implied volatility & & & & & $\begin{array}{l}-0.072 \\
(0.065)\end{array}$ \\
\hline Controls for projects in each stage & No & Yes & Yes & Yes & Yes \\
\hline Firm FE & Yes & Yes & Yes & Yes & Yes \\
\hline Year FE & Yes & Yes & Yes & Yes & Yes \\
\hline Primary mineral FE & No & No & No & Yes & Yes \\
\hline Number of firms & 177 & 174 & 146 & 144 & 129 \\
\hline Observations & 838 & 822 & 694 & 681 & 606 \\
\hline$R^{2}$ & 0.289 & 0.299 & 0.296 & 0.296 & 0.307 \\
\hline
\end{tabular}


Table 6-Continued

\begin{tabular}{|c|c|c|c|c|c|}
\hline \multicolumn{6}{|l|}{ Panel B: Liability indicators } \\
\hline \multirow[t]{2}{*}{ Dependent variable $=$} & \multicolumn{5}{|c|}{ Likelihood of beginning construction on an NPV + project } \\
\hline & $(1)$ & $(2)$ & $(3)$ & $(4)$ & $(5)$ \\
\hline $\mathbb{1}_{\mathrm{SB} \geq \mathrm{NPV}}$ & $\begin{array}{c}-0.232^{* *} \\
(0.116)\end{array}$ & $\begin{array}{c}-0.264^{* *} \\
(0.109)\end{array}$ & $\begin{array}{c}-0.278^{* *} \\
(0.109)\end{array}$ & $\begin{array}{c}-0.248^{* *} \\
(0.095)\end{array}$ & $\begin{array}{c}-0.357^{* *} \\
(0.179)\end{array}$ \\
\hline $\mathbb{1}_{\mathrm{EB} \geq \mathrm{NPV}}$ & $\begin{array}{c}0.013 \\
(0.072)\end{array}$ & $\begin{array}{c}-0.019 \\
(0.082)\end{array}$ & $\begin{array}{c}0.003 \\
(0.085)\end{array}$ & $\begin{array}{c}0.008 \\
(0.092)\end{array}$ & $\begin{array}{c}0.017 \\
(0.100)\end{array}$ \\
\hline $\mathbb{1}_{\mathrm{TD} \geq \mathrm{NPV}}$ & $\begin{array}{c}-0.018 \\
(0.066)\end{array}$ & $\begin{array}{c}-0.034 \\
(0.071)\end{array}$ & $\begin{array}{l}-0.029 \\
(0.070)\end{array}$ & $\begin{array}{l}-0.032 \\
(0.073)\end{array}$ & $\begin{array}{l}-0.027 \\
(0.074)\end{array}$ \\
\hline Log of book assets & & $\begin{array}{c}0.022 \\
(0.014)\end{array}$ & $\begin{array}{c}0.017 \\
(0.015)\end{array}$ & $\begin{array}{c}0.016 \\
(0.016)\end{array}$ & $\begin{array}{c}0.006 \\
(0.019)\end{array}$ \\
\hline Cash & & $\begin{array}{c}0.049 \\
(0.058)\end{array}$ & $\begin{array}{c}0.037 \\
(0.062)\end{array}$ & $\begin{array}{c}0.040 \\
(0.063)\end{array}$ & $\begin{array}{c}0.052 \\
(0.067)\end{array}$ \\
\hline ROA & & $\begin{array}{l}-0.015 \\
(0.012)\end{array}$ & $\begin{array}{l}-0.015 \\
(0.015)\end{array}$ & $\begin{array}{l}-0.017 \\
(0.015)\end{array}$ & $\begin{array}{l}-0.012 \\
(0.016)\end{array}$ \\
\hline Tobin's $Q$ & & $\begin{array}{c}0.000 \\
(0.005)\end{array}$ & $\begin{array}{l}-0.001 \\
(0.006)\end{array}$ & $\begin{array}{l}-0.002 \\
(0.007)\end{array}$ & $\begin{array}{l}-0.003 \\
(0.008)\end{array}$ \\
\hline Log of firm age & & $\begin{array}{l}-0.052 \\
(0.064)\end{array}$ & $\begin{array}{l}-0.029 \\
(0.072)\end{array}$ & $\begin{array}{l}-0.034 \\
(0.074)\end{array}$ & $\begin{array}{l}-0.018 \\
(0.070)\end{array}$ \\
\hline Project NPV (\$100Ms) & & $\begin{array}{l}0.012^{*} \\
(0.006)\end{array}$ & $\begin{array}{c}0.012 \\
(0.008)\end{array}$ & $\begin{array}{c}0.012 \\
(0.008)\end{array}$ & $\begin{array}{c}0.011 \\
(0.008)\end{array}$ \\
\hline Project Capital Costs $(\$ 100 \mathrm{Ms})$ & & $\begin{array}{c}-0.013^{*} \\
(0.007)\end{array}$ & $\begin{array}{l}-0.011 \\
(0.007)\end{array}$ & $\begin{array}{c}-0.011^{*} \\
(0.006)\end{array}$ & $\begin{array}{l}-0.009 \\
(0.007)\end{array}$ \\
\hline Expected mine life & & $\begin{array}{l}-0.004 \\
(0.004)\end{array}$ & $\begin{array}{l}-0.005 \\
(0.005)\end{array}$ & $\begin{array}{l}-0.005 \\
(0.007)\end{array}$ & $\begin{array}{c}-0.007 \\
(0.008)\end{array}$ \\
\hline Total NPV of alternative projects $(\$ 100 \mathrm{Ms})$ & & $\begin{array}{c}-0.015 \\
(0.011)\end{array}$ & $\begin{array}{l}-0.014 \\
(0.011)\end{array}$ & $\begin{array}{c}-0.013 \\
(0.011)\end{array}$ & $\begin{array}{l}-0.010 \\
(0.011)\end{array}$ \\
\hline Start alternative NPV + project & & $\begin{array}{l}-0.023 \\
(0.109)\end{array}$ & $\begin{array}{l}-0.016 \\
(0.112)\end{array}$ & $\begin{array}{l}-0.003 \\
(0.112)\end{array}$ & $\begin{array}{c}0.011 \\
(0.112)\end{array}$ \\
\hline Primary mineral price (\% ch.) & & & $\begin{array}{l}-0.025 \\
(0.058)\end{array}$ & & \\
\hline Futures price & & & & $\begin{array}{l}0.012 \\
(0.015)\end{array}$ & $\begin{array}{c}0.008 \\
(0.013)\end{array}$ \\
\hline Options-implied volatility & & & & & $\begin{array}{l}-0.100 \\
(0.064)\end{array}$ \\
\hline Controls for projects in each stage & No & Yes & Yes & Yes & Yes \\
\hline Firm FE & Yes & Yes & Yes & Yes & Yes \\
\hline Year FE & Yes & Yes & Yes & Yes & Yes \\
\hline Primary mineral FE & No & No & No & Yes & Yes \\
\hline Number of firms & 177 & 174 & 146 & 144 & 129 \\
\hline Observations & 838 & 822 & 694 & 681 & 606 \\
\hline$R^{2}$ & 0.290 & 0.300 & 0.297 & 0.298 & 0.302 \\
\hline
\end{tabular}


Table 7: Firm liabilities and time until beginning construction on positive NPV projects. This table reports the results of Cox proportional hazards model regressions. The reported coefficients are the hazard ratios. The sample is comprised of project-year observations for mining projects from the year the firm publicly discloses the NI 43-101 technical report that includes the initial NPV estimate to the year the firm begins construction on the mine, or the sample period ends, whichever comes first. The sample consists of firms listed on the Toronto Stock Exchange (TSX) or Toronto Stock Exchange Venture (TSXV) and located in Canada over the sample period of 2003 to 2016 . The "event" is when the firm begins construction on the project. $S B / M V$ is the sum of estimated reclamation liabilities of all of a firm's producing mines defined as self-bonded divided by the market value of the firm's assets. $E B / M V$ is the sum of estimated reclamation liabilities of all of a firm's producing mines defined as externally-bonded (guaranteed with a surety bond, letter of credit, etc.) divided by the market value of the firm's assets. $\mathbb{1}_{\mathrm{SB} \geq \mathrm{NPV}}$ is an indicator variable that equals 1 if the sum of estimated reclamation liabilities of all of a firm's producing mines defined as self-bonded exceeds the initial NPV estimate of the mining project. $\mathbb{1}_{\mathrm{EB} \geq \mathrm{NPV}}$ is an indicator variable that equals 1 if the sum of estimated reclamation liabilities of all of a firm's producing mines defined as externally-bonded (guaranteed with a surety bond, letter of credit, etc.) exceeds the initial NPV estimate of the mining project. $\mathbb{1}_{\mathrm{TD} \geq \mathrm{NPV}}$ is an indicator variable that equals 1 if the firm's traditional debt exceeds the initial NPV estimate of the mining project. The data on estimated reclamation liabilities were hand-collected from firms' public disclosures. Self-bonded and externally-bonded mines are classified using the self-bonding regulations in Table 1 according to the description in Section 3.1. In both Panels A and $\mathrm{B}$, the unreported time-varying coefficients used in Model (2) are log of book assets, cash, ROA, and Tobin's $Q$, log of firm age, the number of projects in each mining stage, the total NPV of the firm's alternative mining projects, and a dummy variable if the firm starts construction on an alternative project. The unreported time-varying coefficients used in Model (3) include those in Model (2), as well as the annual percentage change in the price of the primary mineral extracted. Models (4) and (5) add the 12-month futures price and the implied volatility from historical put-call straddles, respectively. These variables (defined in Appendix Table A1) are constructed using data from Compustat-North America, Mining Intelligence, and Bloomberg. Robust standard errors, clustered at the firm level, are reported in parentheses. ${ }^{*}, * *$, and *** denote significance at the $10 \%, 5 \%$, and $1 \%$ level, respectively.

\begin{tabular}{lccccc}
\hline Panel A: Liability ratios & \multicolumn{5}{c}{ Survival analysis } \\
\cline { 2 - 6 } & $(1)$ & $(2)$ & $(3)$ & $(4)$ & $(5)$ \\
\hline SB/MV & $0.378^{*}$ & 0.691 & 0.710 & 0.726 & 0.670 \\
& $(0.209)$ & $(0.300)$ & $(0.280)$ & $(0.285)$ & $(0.264)$ \\
EB/MV & 0.523 & 0.671 & 0.735 & 0.771 & 0.152 \\
& $(0.478)$ & $(0.492)$ & $(0.431)$ & $(0.355)$ & $(0.309)$ \\
Market leverage & 0.934 & 1.198 & 1.024 & 1.046 & 0.908 \\
& $(0.391)$ & $(0.576)$ & $(0.527)$ & $(0.534)$ & $(0.442)$ \\
Project capital costs $(\$ 100 \mathrm{Ms})$ & & 0.987 & 0.970 & 0.978 & 1.005 \\
& & $(0.029)$ & $(0.038)$ & $(0.052)$ & $(0.050)$ \\
Project NPV(\$100Ms) & & 1.018 & 1.021 & 1.021 & 1.018 \\
& & $(0.028)$ & $(0.025)$ & $(0.025)$ & $(0.024)$ \\
Expected mine life & & 1.027 & 1.040 & 1.038 & 1.009 \\
& & $(0.041)$ & $(0.047)$ & $(0.046)$ & $(0.032)$ \\
Year FE & Yes & Yes & Yes & Yes & Yes \\
Primary mineral FE & Yes & Yes & Yes & Yes & Yes \\
Time-varying coefficients & No & Yes & Yes & Yes & Yes \\
Number of firms & 191 & 189 & 160 & 158 & 145 \\
Observations & 958 & 947 & 836 & 827 & 768 \\
Pseudo- $R^{2}$ & 0.106 & 0.125 & 0.119 & 0.119 & 0.146 \\
\hline
\end{tabular}


Table 7-Continued

\begin{tabular}{lccccc}
\hline Panel B: Liability indicators & \multicolumn{5}{c}{ Survival analysis } \\
\cline { 2 - 6 } & $(1)$ & $(2)$ & $(3)$ & $(4)$ & $(5)$ \\
\hline $\mathbb{1}_{\mathrm{SB} \geq \mathrm{NPV}}$ & $0.338^{* * *}$ & $0.473^{*}$ & $0.471^{* *}$ & $0.478^{* *}$ & $0.467^{* *}$ \\
& $(0.129)$ & $(0.193)$ & $(0.166)$ & $(0.169)$ & $(0.156)$ \\
$\mathbb{1}_{\mathrm{EB} \geq \mathrm{NPV}}$ & 0.759 & 0.918 & 0.842 & 0.869 & 0.629 \\
& $(0.415)$ & $(0.527)$ & $(0.464)$ & $(0.489)$ & $(0.368)$ \\
$\mathbb{1}_{\mathrm{TD} \geq \mathrm{NPV}}$ & 0.978 & 0.896 & 0.893 & 0.885 & 0.858 \\
& $(0.303)$ & $(0.334)$ & $(0.327)$ & $(0.324)$ & $(0.316)$ \\
Project capital costs $(\$ 100 \mathrm{Ms})$ & & 0.968 & 0.946 & 0.951 & 0.937 \\
& & $(0.038)$ & $(0.044)$ & $(0.050)$ & $(0.052)$ \\
Project NPV(\$100Ms) & & 1.025 & 1.030 & 1.028 & 1.036 \\
& & $(0.029)$ & $(0.025)$ & $(0.025)$ & $(0.023)$ \\
Expected mine life & & 1.025 & 1.038 & 1.038 & 1.026 \\
& & $(0.036)$ & $(0.039)$ & $(0.038)$ & $(0.037)$ \\
Year FE & Yes & Yes & Yes & Yes & Yes \\
Primary mineral FE & Yes & Yes & Yes & Yes & Yes \\
Time-varying coefficients & No & Yes & Yes & Yes & Yes \\
& & & & & \\
Number of firms & 191 & 189 & 160 & 158 & 145 \\
Observations & 958 & 947 & 836 & 827 & 768 \\
Pseudo- $R^{2}$ & 0.107 & 0.124 & 0.118 & 0.118 & 0.127 \\
\hline
\end{tabular}


Table 8: Risky firm liabilities and positive NPV projects. This table reports the results of linear probability models to analyze how more plausibly risky firm liabilities affect investment in positive NPV projects. The dependent variable in Models (1) and (2) is the likelihood a firm acquires the rights to a new positive net present value (NPV+) mining project. The NPV of the mining rights is defined as the value of the NPV estimate in the NI 43-101 technical reports less the cost the acquiring firm paid for the individual mine at acquisition. The sample in Models (1) and (2) consists of firms listed on the Toronto Stock Exchange (TSX) or Toronto Stock Exchange Venture (TSXV) and located in Canada over the sample period of 1990 to 2016. The dependent variable for Models (3) through (6) is the likelihood of beginning construction on a positive net present value (NPV+) project. The sample is comprised of project-year observations for mining projects from the year the firm publicly discloses the NI 43-101 technical report that includes the initial NPV estimate to the year the firm begins construction on the mine, or the sample period ends, whichever comes first. The sample in Models (3) through (6) consists of firms listed on the Toronto Stock Exchange (TSX) or Toronto Stock Exchange Venture (TSXV) and located in Canada over the sample period of 2003 to 2016. $S B / M V$ is the sum of estimated reclamation liabilities of all of a firm's producing mines defined as self-bonded divided by the market value of the firm's assets. $E B / M V$ is the sum of estimated reclamation liabilities of all of a firm's producing mines defined as externally-bonded (guaranteed with a surety bond, letter of credit, etc.) divided by the market value of the firm's assets. $\mathbb{1}_{\mathrm{SB}>\mathrm{NPV}}$ is an indicator variable that equals 1 if the sum of estimated reclamation liabilities of all of a firm's producing mines defined as self-bonded exceeds the initial NPV estimate of the mining project. $\mathbb{1}_{\mathrm{EB}} \geq \mathrm{NPV}$ is an indicator variable that equals 1 if the sum of estimated reclamation liabilities of all of a firm's producing mines defined as externally-bonded (guaranteed with a surety bond, letter of credit, etc.) exceeds the initial NPV estimate of the mining project. $\mathbb{1}_{\mathrm{TD}}>\mathrm{NPV}$ is an indicator variable that equals 1 if the firm's traditional debt exceeds the initial NPV estimate of the mining project. The data on estimated reclamation liabilities were hand-collected from firms' public disclosures. Self-bonded and externally-bonded mines are classified using the self-bonding regulations in Table 1 according to the description in Section 3.1. Downgrade period is an indicator variable that equals 1 in the year of, and the year prior to, any security downgrade for a particular firm, and 0 otherwise. The additional control variables (defined in Appendix Table A1) are constructed using data from Compustat-North America, Mining Intelligence, and Bloomberg. Models (1), (3), and (5) exclude firms that have an investment grade bond rating at some point over the sample period. Robust standard errors, clustered at the firm level, are reported in parentheses. $* * *$, and $* * *$ denote significance at the $10 \%, 5 \%$, and $1 \%$ level, respectively.

\begin{tabular}{|c|c|c|c|c|c|c|}
\hline \multirow[t]{2}{*}{ Dependent variable $=$} & \multicolumn{2}{|c|}{ Acquire rights } & \multicolumn{4}{|c|}{ Begin construction } \\
\hline & $(1)$ & $(2)$ & $(3)$ & $(4)$ & $(5)$ & $(6)$ \\
\hline $\mathrm{SB} / \mathrm{MV}$ & $\begin{array}{c}-0.023^{* * *} \\
(0.007)\end{array}$ & $\begin{array}{c}-0.025^{* * *} \\
(0.006)\end{array}$ & $\begin{array}{c}-0.058 * * * \\
(0.012)\end{array}$ & $\begin{array}{c}-0.054^{* * *} \\
(0.014)\end{array}$ & & \\
\hline $\mathrm{EB} / \mathrm{MV}$ & $\begin{array}{l}0.001^{* *} \\
(0.001)\end{array}$ & $\begin{array}{l}0.001^{*} \\
(0.001)\end{array}$ & $\begin{array}{l}-0.004 \\
(0.063)\end{array}$ & $\begin{array}{c}0.004 \\
(0.061)\end{array}$ & & \\
\hline Market leverage & $\begin{array}{l}-0.026^{*} \\
(0.015)\end{array}$ & $\begin{array}{l}-0.023 \\
(0.017)\end{array}$ & $\begin{array}{l}-0.004 \\
(0.055)\end{array}$ & $\begin{array}{l}-0.006 \\
(0.062)\end{array}$ & & \\
\hline $\mathbb{1}_{\mathrm{SB} \geq \mathrm{NPV}}$ & & & & & $\begin{array}{c}-0.414^{* * *} \\
(0.157)\end{array}$ & $\begin{array}{r}-0.284^{*} \\
(0.148)\end{array}$ \\
\hline $\mathbb{1}_{\mathrm{EB} \geq \mathrm{NPV}}$ & & & & & $\begin{array}{l}-0.019 \\
(0.097)\end{array}$ & $\begin{array}{c}0.013 \\
(0.086)\end{array}$ \\
\hline $\mathbb{1}_{\mathrm{TD} \geq \mathrm{NPV}}$ & & & & & $\begin{array}{c}0.003 \\
(0.132)\end{array}$ & $\begin{array}{l}-0.052 \\
(0.121)\end{array}$ \\
\hline $\mathrm{SB} / \mathrm{MV} \times$ downgrade period & & $\begin{array}{c}-0.161^{* * *} \\
(0.053)\end{array}$ & & $\begin{array}{c}-0.368^{* *} \\
(0.141)\end{array}$ & & \\
\hline $\mathrm{EB} / \mathrm{MV} \times$ downgrade period & & $\begin{array}{l}0.044^{*} \\
(0.024)\end{array}$ & & $\begin{array}{c}0.052 \\
(0.175)\end{array}$ & & \\
\hline Market leverage $\times$ downgrade period & & $\begin{array}{l}-0.008 \\
(0.005)\end{array}$ & & $\begin{array}{l}-0.002 \\
(0.037)\end{array}$ & & \\
\hline $\mathbb{1}_{\mathrm{SB} \geq \mathrm{NPV}} \times$ downgrade period & & & & & & $\begin{array}{l}-0.170^{*} \\
(0.097)\end{array}$ \\
\hline $\mathbb{1}_{\mathrm{EB} \geq \mathrm{NPV}} \times$ downgrade period & & & & & & $\begin{array}{c}0.092 \\
(0.197)\end{array}$ \\
\hline $\mathbb{1}_{\mathrm{TD} \geq \mathrm{NPV}} \times$ downgrade period & & & & & & $\begin{array}{c}0.137 \\
(0.138)\end{array}$ \\
\hline Downgrade period & & $\begin{array}{c}0.002 \\
(0.003)\end{array}$ & & $\begin{array}{c}0.005 \\
(0.020)\end{array}$ & & $\begin{array}{l}0.028 \\
(0.085)\end{array}$ \\
\hline Exclude investment grade firms & Yes & No & Yes & No & Yes & No \\
\hline Additional controls & Yes & Yes & Yes & Yes & Yes & Yes \\
\hline Firm FE & Yes & Yes & Yes & Yes & Yes & Yes \\
\hline Year FE & Yes & Yes & Yes & Yes & Yes & Yes \\
\hline Number of firms & 756 & 775 & 170 & 174 & 170 & 174 \\
\hline Observations & 6,361 & 6,747 & 791 & 822 & 791 & 822 \\
\hline$R^{2}$ & 0.133 & 0.167 & 0.312 & 0.300 & 0.312 & 0.302 \\
\hline
\end{tabular}


Table 9: Short maturity liabilities and asset volatility in bad times. This table reports the results of linear probability models in which the dependent variable is the likelihood of beginning construction on a positive net present value $(\mathrm{NPV}+)$ project. The sample is comprised of project-year observations for mining projects from the year the firm publicly discloses the NI 43-101 technical report that includes the initial NPV estimate to the year the firm begins construction on the mine, or the sample period ends, whichever comes first. The sample consists of firms listed on the Toronto Stock Exchange (TSX) or Toronto Stock Exchange Venture (TSXV) and located in Canada over the sample period of 2003 to 2016. $S B / M V_{\text {Mature }}$ is the sum of estimated reclamation liabilities of all of a firm's producing mines defined as self-bonded and created at least eight years prior, divided by the market value of the firm's assets. $E B / M V_{\text {Mature }}$ is the sum of estimated reclamation liabilities of all of a firm's producing mines defined as externally-bonded (guaranteed with a surety bond, letter of credit, etc.) and created

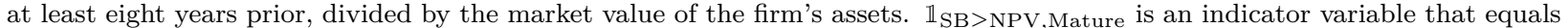
1 if the sum of estimated reclamation liabilities of all of a firm's producing mines defined as self-bonded and created at least eight years prior exceeds the initial NPV estimate of the mining project. $\mathbb{1}_{\mathrm{EB}}>\mathrm{NPV}$, Mature is an indicator variable that equals 1 if the sum of estimated reclamation liabilities of all of a firm's producing mines defined as externally-bonded (guaranteed with a surety bond, letter of credit, etc.) and created at least eight years prior exceeds the initial NPV estimate of the mining project. $\mathbb{1}_{\mathrm{TD}} \geq \mathrm{NPV}$ is an indicator variable that equals 1 if the firm's traditional debt exceeds the initial NPV estimate of the mining project. The data on estimated reclamation liabilities were hand-collected from firms' public disclosures. Self-bonded and externally-bonded mines are classified using the self-bonding regulations in Table 1 according to the description in Section 3.1. The TXGM is annual December values of the S\&P/TSX Global Mining Index. The additional control variables are the same as those in Table 6, Model (2). The accounting variables (defined in Appendix Table A1) are constructed using data from Compustat - North America and the data on firms' mining projects is provided by Mining Intelligence. Robust standard errors, clustered at the firm level, are reported in parentheses. ${ }^{*}, * *$, and $* * *$ denote significance at the $10 \%, 5 \%$, and $1 \%$ level, respectively.

\begin{tabular}{|c|c|c|c|c|c|c|c|c|}
\hline \multirow{2}{*}{$\begin{array}{l}\text { Dependent variable }= \\
\text { Sample }=\end{array}$} & \multicolumn{8}{|c|}{ Likelihood of beginning construction on an NPV + project } \\
\hline & $\begin{array}{l}\text { All } \\
(1)\end{array}$ & $\begin{array}{l}\text { All } \\
(2)\end{array}$ & $\begin{array}{l}\text { Non-gold } \\
(3)\end{array}$ & $\begin{array}{c}\text { Gold } \\
(4)\end{array}$ & $\begin{array}{l}\text { All } \\
(5)\end{array}$ & $\begin{array}{l}\text { All } \\
(6)\end{array}$ & $\begin{array}{l}\text { Non-gold } \\
(7)\end{array}$ & $\begin{array}{c}\text { Gold } \\
(8)\end{array}$ \\
\hline $\mathrm{SB} / \mathrm{MV}_{\mathrm{Maturity}} \geq 8$ years & $\begin{array}{l}-0.142 \\
(0.157)\end{array}$ & $\begin{array}{c}-0.361^{* *} \\
(0.164)\end{array}$ & $\begin{array}{c}-0.294^{*} \\
(0.156)\end{array}$ & $\begin{array}{l}-1.837 \\
(9.927)\end{array}$ & & & & \\
\hline $\mathrm{EB} / \mathrm{MV}_{\text {Maturity }} \geq 8$ years & $\begin{array}{l}-0.018 \\
(0.095)\end{array}$ & $\begin{array}{c}0.912 \\
(0.876)\end{array}$ & 4.873 & 0.366 & & & & \\
\hline Market leverage & $\begin{array}{c}0.001 \\
(0.056)\end{array}$ & $\begin{array}{c}0.141 \\
(0.173)\end{array}$ & $\begin{array}{c}0.181 \\
(0.215)\end{array}$ & $\begin{array}{l}-0.060 \\
(0.403)\end{array}$ & & & & \\
\hline $\mathbb{1}_{\mathrm{SB} \geq \mathrm{NPV}, \text { Maturity } \geq 8 \text { years }}$ & & & & & $\begin{array}{c}-0.253^{* *} \\
(0.125)\end{array}$ & $\begin{array}{c}-1.065^{* *} \\
(0.478)\end{array}$ & $\begin{array}{c}-2.891^{* * *} \\
(0.673)\end{array}$ & $\begin{array}{l}-1.190 \\
(0.874)\end{array}$ \\
\hline $\mathbb{1}_{\mathrm{EB}} \geq \mathrm{NPV}$, Maturity $\geq 8$ years & & & & & & & & $\begin{array}{c}0.140 \\
(0.275)\end{array}$ \\
\hline $\mathbb{1}_{\mathrm{TD} \geq \mathrm{NPV}}$ & & & & & $\begin{array}{l}-0.038 \\
(0.071)\end{array}$ & $\begin{array}{l}-0.138 \\
(0.155)\end{array}$ & $\begin{array}{l}-0.118 \\
(0.383)\end{array}$ & $\begin{array}{l}-0.058 \\
(0.260)\end{array}$ \\
\hline 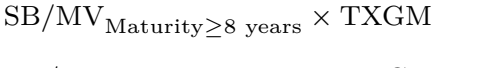 & & $\begin{array}{c}0.005 \\
(0.003)\end{array}$ & $\begin{array}{c}0.005^{* *} \\
(0.002)\end{array}$ & $\begin{array}{l}-0.089 \\
(0.208)\end{array}$ & & & & \\
\hline 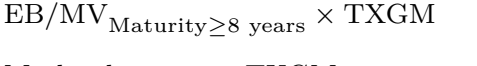 & & $\begin{array}{l}-0.021 \\
(0.017)\end{array}$ & $\begin{array}{l}-0.083 \\
(0.062)\end{array}$ & $\begin{array}{l}-0.011 \\
(0.012)\end{array}$ & & & & \\
\hline Market leverage $\times$ TXGM & & $\begin{array}{l}-0.003 \\
(0.003)\end{array}$ & $\begin{array}{l}-0.003 \\
(0.003)\end{array}$ & $\begin{array}{l}0.001 \\
(0.007)\end{array}$ & & & & \\
\hline $\mathbb{1}_{\mathrm{SB} \geq \mathrm{NPV}, \text { Maturity }} \geq 8$ years $\times \mathrm{TXGM}$ & & & & & & $\begin{array}{c}0.009^{* *} \\
(0.005)\end{array}$ & $\begin{array}{c}0.026^{* * *} \\
(0.009)\end{array}$ & $\begin{array}{c}0.014 \\
(0.011)\end{array}$ \\
\hline $\mathbb{1}_{\mathrm{EB} \geq \mathrm{NPV}, \text { Maturity } \geq 8 \text { years }} \times \mathrm{TXGM}$ & & & & & & $\begin{array}{l}-0.001 \\
(0.002)\end{array}$ & $\begin{array}{l}-0.006 \\
(0.007)\end{array}$ & $\begin{array}{l}-0.001 \\
(0.004)\end{array}$ \\
\hline $\mathbb{1}_{\mathrm{TD} \geq \mathrm{NPV}} \times \mathrm{TXGM}$ & & & & & & $\begin{array}{c}0.001 \\
(0.002)\end{array}$ & $\begin{array}{l}-0.001 \\
(0.004)\end{array}$ & $\begin{array}{c}0.001 \\
(0.003)\end{array}$ \\
\hline Additional controls & Yes & Yes & Yes & Yes & Yes & Yes & Yes & Yes \\
\hline Firm FE & Yes & Yes & Yes & Yes & Yes & Yes & Yes & Yes \\
\hline Year FE & Yes & Yes & Yes & Yes & Yes & Yes & Yes & Yes \\
\hline Number of firms & 174 & 173 & 101 & 82 & 174 & 173 & 101 & 82 \\
\hline Observations & 822 & 813 & 474 & 334 & 822 & 813 & 474 & 334 \\
\hline$R^{2}$ & 0.296 & 0.298 & 0.340 & 0.355 & 0.300 & 0.304 & 0.377 & 0.345 \\
\hline
\end{tabular}


Table 10: Firm liabilities and capital expenditures. This table reports the results of linear regression models in which the dependent variable is capital expenditures (as a percentage of a firm's total book assets). In Models (1) through (3) the sample consists of firms listed on the Toronto Stock Exchange (TSX) or Toronto Stock Exchange Venture (TSXV) and located in Canada over the sample period of 1990 to 2016. The sample period in Model (4) is 2003 to 2016 to match the sample used in the project-level analysis. $S B / M V$ is the sum of estimated reclamation liabilities of all a firm's producing mines defined as self-bonded divided by the market value of the firm's assets. $E B / M V$ is the sum of estimated reclamation liabilities of all a firm's producing mines defined as externallybonded (guaranteed with a surety bond, letter of credit, etc.) divided by the market value of the firm's assets. The data on estimated reclamation liabilities were hand-collected from firms' public disclosures. Self-bonded and externally-bonded mines are classified using the self-bonding regulations in Table 1 according to the description in Section 3.1. Accounting variables (defined in Appendix Table A1) are constructed using data from CompustatNorth America and the data on firms' mining projects were provide by Intelligence Mining. Robust standard errors, clustered at the firm level, are reported in parentheses. ${ }^{*},{ }^{* *}$, and *** denote significance at the $10 \%, 5 \%$, and $1 \%$ level, respectively.

\begin{tabular}{|c|c|c|c|c|}
\hline \multirow[t]{2}{*}{ Dependent variable $=$} & \multicolumn{4}{|c|}{ Capital expenditures } \\
\hline & $(1)$ & $(2)$ & $(3)$ & $(4)$ \\
\hline $\mathrm{SB} / \mathrm{MV}$ & $\begin{array}{c}-0.023^{* * *} \\
(0.003)\end{array}$ & $\begin{array}{c}-0.022^{* * *} \\
(0.003)\end{array}$ & $\begin{array}{c}-0.022^{* * *} \\
(0.003)\end{array}$ & $\begin{array}{c}-0.021^{* * *} \\
(0.003)\end{array}$ \\
\hline $\mathrm{EB} / \mathrm{MV}$ & $\begin{array}{c}-0.004^{* * *} \\
(0.001)\end{array}$ & $\begin{array}{c}-0.003^{* * *} \\
(0.001)\end{array}$ & $\begin{array}{c}-0.003^{* * *} \\
(0.001)\end{array}$ & $\begin{array}{c}-0.003^{* * *} \\
(0.001)\end{array}$ \\
\hline Market leverage & $\begin{array}{l}-0.022 \\
(0.017)\end{array}$ & $\begin{array}{c}-0.038^{* *} \\
(0.017)\end{array}$ & $\begin{array}{l}-0.028 \\
(0.017)\end{array}$ & $\begin{array}{l}-0.033^{*} \\
(0.018)\end{array}$ \\
\hline Market leverage $\times$ Tobin's $Q$ & & & $\begin{array}{c}-0.003^{* *} \\
(0.001)\end{array}$ & \\
\hline Log of book assets & & $\begin{array}{c}0.004 \\
(0.004)\end{array}$ & $\begin{array}{c}0.004 \\
(0.004)\end{array}$ & $\begin{array}{c}0.010^{* * *} \\
(0.004)\end{array}$ \\
\hline Cash & & $\begin{array}{c}-0.085^{* * *} \\
(0.013)\end{array}$ & $\begin{array}{c}-0.086^{* * *} \\
(0.013)\end{array}$ & $\begin{array}{c}-0.101^{* * *} \\
(0.014)\end{array}$ \\
\hline $\mathrm{ROA}$ & & $\begin{array}{c}-0.012^{* * *} \\
(0.002)\end{array}$ & $\begin{array}{c}-0.012^{* * *} \\
(0.002)\end{array}$ & $\begin{array}{c}-0.013^{* * *} \\
(0.002)\end{array}$ \\
\hline Tobin's $Q$ & & $\begin{array}{c}-0.002^{* *} \\
(0.001)\end{array}$ & $\begin{array}{l}-0.001^{*} \\
(0.001)\end{array}$ & $\begin{array}{c}-0.002^{* * * *} \\
(0.001)\end{array}$ \\
\hline Log of firm age & & $\begin{array}{c}-0.034^{* * *} \\
(0.010)\end{array}$ & $\begin{array}{c}-0.034^{* * *} \\
(0.010)\end{array}$ & $\begin{array}{c}-0.039^{* * * *} \\
(0.010)\end{array}$ \\
\hline \# of mines in exploration & & $\begin{array}{c}0.001 \\
(0.001)\end{array}$ & $\begin{array}{c}0.001 \\
(0.001)\end{array}$ & $\begin{array}{c}0.000 \\
(0.001)\end{array}$ \\
\hline \# of mines in feasibility & & $\begin{array}{l}0.002 \\
(0.006)\end{array}$ & $\begin{array}{c}0.002 \\
(0.006)\end{array}$ & $\begin{array}{c}0.002 \\
(0.006)\end{array}$ \\
\hline \# of mines in construction/permitting & & $\begin{array}{c}0.025^{* *} \\
(0.011)\end{array}$ & $\begin{array}{c}0.025^{* *} \\
(0.011)\end{array}$ & $\begin{array}{c}0.024^{* *} \\
(0.011)\end{array}$ \\
\hline \# of producing mines & & $\begin{array}{l}-0.002 \\
(0.003)\end{array}$ & $\begin{array}{l}-0.002 \\
(0.003)\end{array}$ & $\begin{array}{l}-0.002 \\
(0.004)\end{array}$ \\
\hline \# of closed mines & & $\begin{array}{c}0.000 \\
(0.006)\end{array}$ & $\begin{array}{c}0.000 \\
(0.006)\end{array}$ & $\begin{array}{c}0.003 \\
(0.009)\end{array}$ \\
\hline Firm FE & Yes & Yes & Yes & Yes \\
\hline Year FE & Yes & Yes & Yes & Yes \\
\hline Number of firms & 790 & 775 & 775 & 764 \\
\hline Observations & 7,029 & 6,697 & 6,697 & 5,904 \\
\hline$R^{2}$ & 0.354 & 0.387 & 0.388 & 0.415 \\
\hline
\end{tabular}


Table A1: Data Appendix. This table defines the variables used in the empirical tests in the main portion of the paper and lists the data source(s) for each variable.

\begin{tabular}{|c|c|c|}
\hline Variable name & Source & Definition \\
\hline SB & Technical reports, Mining Intelligence & $\begin{array}{l}\text { Sum of estimated reclamation liabilities of producing mines de- } \\
\text { fined as self-bonded }\end{array}$ \\
\hline $\mathrm{EB}$ & Technical reports, Mining Intelligence & $\begin{array}{l}\text { Sum of estimated reclamation liabilities of producing mines de- } \\
\text { fined as externally-bonded }\end{array}$ \\
\hline $\mathrm{SB} / \mathrm{MV}$ & Technical reports, Mining Intelligence, Compustat & $\mathrm{SB} /\left(\left(\right.\right.$ prcc $\left.f^{*} \operatorname{cshpri}\right)+\mathrm{dlc}+\mathrm{dltt}+$ pstkl - txditc $)$ \\
\hline $\mathrm{EB} / \mathrm{MV}$ & Technical reports, Mining Intelligence, Compustat & $\mathrm{EB} /\left(\left(\right.\right.$ prcc_f* $\left.\mathrm{f}^{*} \mathrm{csh} p \mathrm{i}\right)+\mathrm{dlc}+\mathrm{dltt}+$ pstkl - txditc $)$ \\
\hline Market leverage & Compustat & $(\mathrm{dltt}+\mathrm{dlc}) /\left(\left(\right.\right.$ prcc $\left.\_\mathrm{f}^{*} \mathrm{cshpri}\right)+\mathrm{dlc}+\mathrm{dltt}+$ pstkl - txditc $)$ \\
\hline $\mathbb{1}_{\mathrm{SB} \geq \mathrm{NPV}}$ & Technical reports, Mining Intelligence & $\begin{array}{l}\text { Indicator for } \mathrm{SB} \text { that exceed the estimated project net present } \\
\text { value }\end{array}$ \\
\hline $\mathbb{1}_{\mathrm{EB} \geq \mathrm{NPV}}$ & Technical reports, Mining Intelligence & $\begin{array}{l}\text { Indicator for } \mathrm{EB} \text { that exceed the estimated project net present } \\
\text { value }\end{array}$ \\
\hline $\mathbb{1}_{\mathrm{TD} \geq \mathrm{NPV}}$ & Technical reports, Mining Intelligence & $\begin{array}{l}\text { Indicator for total debt liabilities that exceed the estimated } \\
\text { project net present value }\end{array}$ \\
\hline Log of book assets & Compustat & $\log (\mathrm{at})$ \\
\hline Capital expenditures & Compustat & capx/at \\
\hline Return on Assets (ROA) & Compustat & ebitda/at \\
\hline Cash & Compustat & che/at \\
\hline Tobin's $Q$ & Compustat & $\left(\left(\right.\right.$ prcc_f $\left.f^{*} \operatorname{csh} p r i\right)+$ dlc + dltt + pstkl - txditc $) /$ at \\
\hline Log of firm age & Datastream & Log of years since firm listed on TSX or TSXV \\
\hline Project NPV & Mining Intelligence & Initial estimate of project net present value \\
\hline NPV of mining rights & Mining Intelligence & $\begin{array}{l}\text { NPV estimate from NI } 43-101 \text { techinical report (or the remaining } \\
\text { NPV estimated by this reported if the mine is already producing), } \\
\text { less the cost the acquiring firm paid for the individual mine at } \\
\text { acquisition }\end{array}$ \\
\hline Project capital costs & Mining Intelligence & Initial estimate of project capital costs \\
\hline Total NPV of alternative projects & Mining Intelligence & $\begin{array}{l}\text { The total NPV of the firm's alternative mining projects in a given } \\
\text { year }\end{array}$ \\
\hline Start alternative NPV + project & Mining Intelligence & $\begin{array}{l}\text { Indicator for firm starting an alternative NPV }+ \text { project in a given } \\
\text { year }\end{array}$ \\
\hline Primary mineral price (\% ch.) & FRED global price series or producer price indices & $\left(\mathrm{P}_{t}-\mathrm{P}_{t-1}\right) / \mathrm{P}_{t-1}$, where $\mathrm{P}$ is the January price in year $t$ \\
\hline Futures price & Bloomberg & 12-month futures prices for the primary mineral mined \\
\hline Options-implied volatility & Bloomberg & $\begin{array}{l}\text { Volatility implied by historical } 1 \text {-month, at the money put-call } \\
\text { straddles }\end{array}$ \\
\hline Mine status & Mining Intelligence & Status (exploration, feasibility, production, etc) of mining project \\
\hline Mine type & Mining Intelligence & Type (Surface, open pit, or underground) of mining project \\
\hline Primary commodity & Mining Intelligence & Primary mineral to be extracted \\
\hline Downgrade period & Compustat, Moody's reports & $\begin{array}{l}\text { Indicator for the year of, and year prior to, a security rating down- } \\
\text { grade from S\&P or Moody's }\end{array}$ \\
\hline TXGM & Bloomberg & $\begin{array}{l}\text { December values of the S\&P/TSX Global Mining Index starting } \\
\text { in } 2007\end{array}$ \\
\hline
\end{tabular}




\section{Appendex B}

This Appendix reports results that are mentioned but not tabulated in the main paper. In Section I, I examine the assumption that mining firms always choose to self-bond when they are allowed to do so. In Section II, I describe where reclamation liabilities are likely to fall in bankruptcy priority in the United States. Then in Section III, I report one figure and 13 tables, as outlined below:

1. Figure B1: Assumed SB vs. "reported" SB in Canada

Reference in the main paper: "Indeed, Internet Appendix Figure IA1 shows the correlation between self-bonded reclamation liabilities created under this assumption and a measure of self-bonded reclamation liabilities inferred from firms' annual reports is nearly 80\%." (Section 3.1)

2. Table B1: The cross-section of traditional debt and the likelihood of acquiring the rights to new positive NPV mining projects

Reference in the main paper: "Indeed, Internet Appendix Table IA2 supports this hypothesis using the sample from Table 5 below." (Section 2.3 Footnote 13)

3. Table B2: Low-cash liabilities and positive NPV projects

Reference in the main paper: "Tables IA2 and IA3 examine results when identifying subsets of reclamation liabilities that are more likely to be self-bonded. In particular, self-bonded reclamation liabilities created when a firm appears to be financial constrained (Table IA1), and self-bonded liabilities created under the standards set by U.S. 30 C.F.R. $\$ 800.23$ (Table IA2) yield results similar to those in Section 4." (Section 3.1 Footnote 15)

4. Table B3: Applying U.S. 30 C.F.R. $§ 800.23$ standards to self-bonded reclamation liabilities

Reference in the main paper: "Tables IA2 and IA3 examine results when identifying subsets of reclamation liabilities that are more likely to be self-bonded. In particular, self-bonded reclamation liabilities created when a firm appears to be financial constrained (Table IA1), and self-bonded liabilities created under the standards set by U.S. 30 C.F.R. $\$ 800.23$ (Table IA2) yield results similar to those in Section 4." (Section 3.1 Footnote 15)

5. Table B4: Reclamation liabilities and investment in the U.S.

Reference in the main paper: "Finally, Table IA4 analyzes a small secondary sample of 
U.S. mining firms that voluntarily disclose the amount of their reclamation liabilities and method of financial assurance in annual reports. These results verify the negative correlation between self-bonded reclamation liabilities and investment using capital expenditures as a proxy." (Section 3.1 Footnote 15)

6. Table B5: Firm liabilities and the likelihood of beginning construction on positive NPV projects

Reference in the main paper: "Internet Appendix Table IA5 examines the robustness of Table 6 to the inclusion of alternative fixed effects, such as location, mine type, and primary mineral by year." (Section 4.2.1 Footnote 27)

7. Table B6: Firm liability ratios and the likelihood of permitting a positive NPV project Reference in the main paper: "Internet Appendix Table IA6 addresses this concern by using the fact that many projects have a time gap between the permitting stage and the construction stage." (Section 4.2.1)

8. Table B7: Firm liabilities and the likelihood of selling the rights to positive NPV projects

Reference in the main paper: "For example, Internet Appendix Table IA7 shows that firms with high self-bonded reclamation liabilities attempt to sell positive NPV projects more often than otherwise similar firms." (Section 4.2.2 Footnote 31)

9. Table B8: Excluding local reclamation liabilities for firms headquartered in a province at the time of the law change

Reference in the main paper: "The Internet Appendix reports results that attempt to address this critique. Specifically, Table IA8 replicates the main results in the paper after excluding all reclamation liabilities for mines in a firm's headquarter province when the firm had already begun operations at the time of the law change." (Section 5.1)

10. Table B9: The number of new rights and permits around the passage of self-bonding laws

Reference in the main paper: "Internet Appendix Table IA9 tests this hypothesis for three sets of firms: (1) all firms in my sample, (2) firms with prior mines in the location of the regulation, and (3) firms headquartered in the province of the regulation." (Section 5.1)

Reference in the main paper: "Table IA9 mitigates not only this particular selection concern, but also a confounding variables problem based on geographic clustering." (Section 5.1 Footnote 33)

11. Table B10: Separating the bonding and investment decision makers Reference in the main paper: "Tables IA10 reports the results of tests attempting to separate the bonding decision maker from the investment decision maker." (Section 5.1)

12. Table B11: Rethinking the grandfathering assumption 
Reference in the main paper: "Thus, Table IA11 flips the grandfathering assumption for all regulation changes outside 43 C.F.R §3809." (Section 5.1)

13. Table B12: Which firms self-bond in the U.S.?

Reference in the main paper: "Finally, in Internet Appendix Table IA12, I analyze a small secondary sample of U.S. mining firms that self-report their reclamation liabilities and method of financial assurance in annual reports." (Section 5.1)

14. Table B13: Risky firm liabilities and investment in the U.S.

Reference in the main paper: "Internet Appendix Table IA13 confirms these results using the small secondary sample of U.S. firms and the Shumway distance to default as a proxy for financial distress." (Section 5 Footnote 34) 


\section{The Self-Bonding Assumption}

In this section I examine the assumption that mining firms will always choose to self-bond if they are able to do so. First, I expand on the discussion in the main paper on why this assumption seems reasonable. Second, I present evidence that suggests alternative assumptions yield similar results. Third, I examine U.S. firms that voluntary disclose reclamation liabilities and the corresponding financial assurance method. Finally, I run a small field study on 41 firms I identify as self-bonding in the project-level sample in Section 4.2 of the main paper.

The first argument made in the main text is that externally-bonding can be extremely costly, at least ex ante. The three main forms of external bonds are (1) surety bonds, (2) letters of credit, and (3) collateral bonds. Surety bonds are the most commonly accepted form of external bond, particularly in the United States (Nazzaro, 2005). However, they do impose rather large costs on operators, both in the form of annual premiums and liquidity constraints. Specifically, surety bonds often require an annual premium in the range of 13.5\% (Kuipers, 2000) to 5-6\% (Chelimsky, 1988) of the total reclamation liability. Further, collateral requirement are often up to $100 \%$ (Chelimsky, 1988). For the average mine in my sample, this could mean a firm would need to pay annual premiums of of up to $\$ 27 \mathrm{M} \times 6 \%=$ $\$ 1.62 \mathrm{M}$ per year on top of a $\$ 27 \mathrm{M}$ collateral requirement.

The next most common form of external bond is the letter of credit (Nazzaro, 2005). ${ }^{1}$ Though Kirschner and Grady (2003) write that the premiums for letters of credit can be negligible, the collateral requirements can be prohibitive. Kirschner and Grady (2003) report that collateral requirements can range between $120 \%$ to $200 \%$ of the total reclamation liability. For the average mine in my sample, this amounts to the operator setting aside $\$ 32.4 \mathrm{M}$ to $\$ 54 \mathrm{M}$ upfront. This is a significant liquidity cost for even medium-sized operators.

Secondly, in the main text, I argue that the option to self-bond seems to be heavily

\footnotetext{
${ }^{1}$ From reading through annual reports of Canadian firms (described below), letters of credit seem more prevalent than surety bonds in Canada.
} 
exercised. For example, Nazzaro (2005) reports that in 2005, $\$ 203$ billion in hardrock reclamation liabilities were assured through corporate guarantees. Further, in a survey, Interstate Mining Compact Commission (2014) reports that at least five states had over 50\% of outstanding reclamation bonds guaranteed through self-bonds: Colorado, Indiana, New Mexico, North Dakota, and Wyoming. Finally, anecdotal evidence suggests many companies have extremely large amounts of self-bonds. For example, Hein et al. (2016) report that as of December 31, 2015, Peabody Energy had $\$ 1.15$ billion in self-bonds (66\% of its total reclamation bonds), Apha Natural Resources had $\$ 676.1$ million in self-bonds (62\% of its total reclamation bonds), Arch Coal had $\$ 485.5$ in self-bonds (67\% of its total reclamation bonds), and Cloud Peak Energy had $\$ 200$ million in self-bonds (31\% of its total reclamation bonds).

Lastly, I argue that over-identifying firms as self-bonding works to bias my results downward. That is, this assumption makes it more difficult for me to find significant results. To the extent that my hypothesis regarding reclamation liabilities is accurate, and only unsecured obligations lead to reduced investment, identifying some externally-bonded liabilities as self-bonded only adds noise to my empirical models. However, given economic magnitudes are important, particularly when attempting to quantify the shadow costs of debt overhang, Section 1.1 examines alternative assumptions to identifying firms that self-bond.

\subsection{Robustness to alternative assumptions}

This subsection further discusses two alternative assumptions for identifying self-bonded reclamation liabilities that are briefly mentioned in the main paper. The first uses the argument that firms that are financially constrained are more likely use find self-bonding. I use cash holdings as a proxy for financial constraints. Table B2 replicates the main results in Tables 5 and 6 in the main paper after excluding reclamation liabilities created during

times when firm does not appear to be financially constrained. Specifically, I exclude all reclamation liabilities that were created the year after a firm has cash holdings of greater 
than $25 \%$ of total assets. ${ }^{2}$ The results in Table B2 remain virtually unchanged.

The second alternative assumption I use results from federal restrictions placed on selfbonding applicants in the United States. In particular, 30 C.F.R. $\$ 800.23$ requires that applicants must:

1. have been in continuous operation as a business entity for a period of not less than five years,

2. have a current rating for its most recent bond issuance of 'A' of higher, or

(a) a tangible net worth of at least $\$ 10$ million (or fixed assets in the U.S. of $\$ 20$ million),

(b) a ratio of total liabilities to net worth of 2.5 times or less, and

(c) a ratio of current assets to current liabilities of 1.2 times or greater, and

3. have a total amount of outstanding and proposed self-bonds not exceeding $25 \%$ of the applicant's tangible net worth.

Table B3 places these restrictions on all mines bonded in the United States, and updates the future liabilities accordingly. Once again, the results are qualitatively and quantitatively similar to those in the main paper. That alternative assumptions yield similar results eases concerns that the assumption that all firms self-bond when they are able to drives the entirety of my results.

\subsection{Self-bonding in the United States}

This subsection more deeply explores the mining firms in the United States that choose to voluntarily disclose that amount of both externally-bonded and self-bonded reclamation liabilities in annual reports. In particular, I start by reading through the last year of disclosed data for the 42 firms I am able to identify a dollar amount of reclamation liabilities, as well

\footnotetext{
${ }^{2} 25 \%$ is the sample mean, but the results are not sensitive to using $13 \%$ of assets (the median) or $36 \%$ of assets (P75). I use cash holdings the year prior to avoid conflating low-cash balances because of financial constraints with low-cash balances due to providing cash collateral for the reclamation bond.
} 
as the method of financial assurance (external- or self-bond). I attempt to find the location of each mine owned by the firm and when each mine was permitted by the local authorities. If I cannot find this information, or it is incomplete, I go back in time until I am able to find it, or I get to a point where the firm has not yet started disclosing this data.

The goal of this exercise to is determine the extent that U.S. mining firms that selfdisclose reclamation data bond mines in a way that is consistent with my assumption that firms always self-bond when they are able to do so. The table below summarizes my findings.

\begin{tabular}{lcccc} 
& \multicolumn{4}{c}{ Consistent with my assumption? } \\
\cline { 2 - 5 } & Consistent & Could be consistent & Not consistent & Not enough information \\
\hline Number of firms & 13 & 9 & 7 & 13 \\
Percent of all & $31 \%$ & $21 \%$ & $17 \%$ & $31 \%$ \\
Percent of known & $45 \%$ & $31 \%$ & $24 \%$ & - \\
\hline
\end{tabular}

Out of the 42 firms, a total of 22 are completely consistent or could be completely consistent with my self-bonding assumption. ${ }^{3}$ This accounts for over half of all the firms and over threefourths of the firms I can find enough information to draw a conclusion. That leaves only 7 firms, or $17 \%$, that are not consistent with my main assumption. While not unanimously supportive, the data does reinforce the argument that a majority of firms do self-bond each mine they are allowed to.

\subsection{A field study of Canadian firms identified as self-bonding}

In a final effort to verify the self-bonding assumption, I conduct a small field study of 41 Canadian firms in my sample from Section 4.2 that I identifying as self-bonding. Of the 41 firms, 12 have since either delisted or been acquired. Thus, I email the investor relations department at the remaining 29 firms and ask for data on the amount of reclamation liabilities each year the firm appears in my sample and for the amount of total liabilities that are selfbonded or backed by a corporate or parent guarantee. For firms that do not respond to my email request, I follow-up with phone calls.

\footnotetext{
${ }^{3}$ Depending on the exact permitting date for one or more mines.
} 
At the time of this writing, only six firms have responded. Five of these firms have declined my request, including three that declined because of the topic of my research. Two of the firms declined by simply pointing me to information in the firm's annual reports. For example, Cameco Corporation responded,"You can find all of the information you are looking for in our annual Management's Discussion and Analysis and Financial Statements. We cannot provide data beyond what is in this report." Finally, one firm granted my request and I can verify that this firm does have self-bonded reclamation liabilities during my sample period. [This field study is on-going.]

I also take the advice of the mining firms and read through annual reports for these 29 firms. I find at least one year of disclosure on reclamation liabilities for 23 firms. However, the quality of disclosure on reclamation liabilities is even worse than it is for the U.S. sample. That is, not a single firm explicitly lists self-bonds or corporate guarantees in their annual reports. Nevertheless, it is clear that these firms do indeed self-bond. For example, over half of the firms use a phrase similar to the following in at least one annual report:

"In certain countries in which the Company has operations, it is required to submit, for government approval, a reclamation plan for each of its mining sites that establishes the Company's obligation to reclaim property after minerals have been mined from the site. In some jurisdictions, bonds, letters of credit or other forms of financial assurances are required as security for these reclamation activities. The Company may incur significant costs in connection with these reclamation activities, which may materially exceed the provisions the Company has made for such reclamation. In addition, the unknown nature of possible future additional regulatory requirements and the potential for additional reclamation activities create further uncertainties related to future reclamation costs, which may have a material adverse effect on the Company's financial condition, liquidity or results of operations."

(IAMGold Corporation Annual Report, 2016)

This language is extremely similar to my main assumption that firms always choose to 
self-bond when they permitted to do so. Further consistent with these firms self-bonding, in 22 out of 23 cases, the amount of reported surety bonds, letters of credit, or collateral bonds is insufficient to cover the reported projected future reclamation liabilities. Several of the discrepancies are very large. For example, in 2013, Kinross Gold reported $\$ 1.3$ billion in total reclamation and remediation obligations but only reported $\$ 200.5$ million in external bonds, in this case letters of credit. First Quantum Minerals reported $\$ 1.01$ billion in total restoration provisions in 2014, but only reported letters of guaranteed by cash deposits totaling $\$ 78.5$ million. It is almost certainly the case that at least a portion of these disparities are self-bonds.

Thus, in order to generate some indication of the reliability of my self-bonding measure, I infer that any discrepancy between a firm's total reported reclamation liabilities and the reported external bonds is the amount of corporate or parent guarantees the company uses. The correlation between the "reported" self-bonded reclamation liabilities and self-bonded reclamation liabilities created using the main assumption in my paper is $53 \%$. After excluding three outlier firms, this correlation is $79 \%$. Figure B1 displays this relationship. The data strongly suggests that my main measure of a firm's self-bonded reclamation liabilities is not creating consequential mismeasurement.

\section{General Liabilities and U.S. Bankruptcy Priority}

One of the driving forces in debt overhang is the Merton (1974) put option. That is, equity holders own a put option on the firm because in the event of bankruptcy, the firm simply transfers to debt holders. It is reasonable to question if there is a similar put option for other liabilities and if so, if it is as strong. The stakeholders to these other liabilities include employees (pension liabilities) and local regulators and taxpayers (reclamation liabilities), among others. It is not immediately clear that these stakeholders have strong claims to assets during a typical bankruptcy proceeding. 
First, Lewis and Melwani (2006) and Gorton (2009) each note the immense complexities involved in bankruptcy proceedings, specifically as they pertain to pension liabilities and reclamation liabilities, respectively. Both employees (themselves and through the Pension Benefit Guaranty Corporation's) and local governments have some claim to a firm's assets in bankruptcy proceedings in the U.S. The priority of pension liabilities is addressed in 507(a)(5) of the bankruptcy code entitled "allowed unsecured claims for contributions to an employee benefit plan". Reclamation liabilities, on the other hand, would likely fall under "general unsecured claims". While both of these fall below the 507(a)(3) priority of unsecured creditors, court rulings may work to elevate the claims of these liabilities.

In the case of reclamation liabilities, the Supreme Court concluded in Midlantic Nat'l Bank v. New Jersey Department of Environmental Protection" that "...a trustee may not abandon property in contravention of a state statute or regulation that is reasonably designed to protect public health or safety from identifiable hazards." In a subsequent ruling applying Midlantic, the Sixth Circuit court in In re Wall Tube $\&$ Metal Products Co v. Tennessee Department of Health and Environment 5 found that "Congress' intentions that trustee's efforts 'to marshal and distribute the assets of the estate' give way to the governmental interest in public health and safety." Gorton (2009) argues that with the rulings in Midlantic and In re Wall Tube, and the widespread recognition of the "hazardous nature of abandoned mine features", governmental agencies can successfully advocate that "reclamation must be considered and given high priority in any reorganization or liquidation plan."

Beyond priority in bankruptcy proceedings, an odd but increasingly common agreement between mining firms nearing financial distress and local regulators suggests that the put option is quite strong for reclamation liabilities. Seemingly more and more, firms are agreeing to "superpriority" clauses regarding outstanding (self-bonded) reclamation liabilities. For example, Peabody Energy recently agreed to entitle Illinois State authorities the ability to receive any cash regarding its $\$ 200$ million plus self-bonded reclamation liabilities before

\footnotetext{
${ }^{4} 474$ U.S. 494 (1986)

${ }^{5} 831$ F.2d 118 (6th Cir. 1987)
} 
any other lender or pre-petition creditor. Lazenby (2016) notes that Illinois is the fourth state with such an agreement with Peabody, following Wyoming, New Mexico, and Indiana. According to Storrow (2015), Wyoming and West Virginia have a similar agreement with Alpha Natural Resources. These superpriority clauses effectively transform the self-bonded reclamation liabilities from a junior liability to a senior liability. 


\section{References}

Chelimsky, Eleanor, 1988, Surface mining: Cost and availability of reclamation bonds (Report no. PEMD-88-17), Report to the Chairman, Subcommittee on Environment, Energy, and Natural Resources, Committee on Government Operations, House of Representatives, United States General Accounting Office, Washington, D.C.

Gorton, William T., 2009, Understanding the reclamation surety relationship before and after operator default, Report to the Rocky Mountain Mineral Law Foundation Special Institute on Mine Closure, Financial Assurance, and Final Reclamation, Westminster, CO.

Hein, Jayni F., Ben Snow, Sean Stefanik, and Lauren Webb, 2016, Self-bonding in an era of coal bankruptcy: Recommendations for reform, Institute for Policy Integrity, NYU School of Law.

Interstate Mining Compact Commission, 2014, Self-bonding survey.

Kirschner, Lisa A., and Edward B. Grady, 2003, Mining and the vanishing surety bond market, Natural Resources \& Environment 17, 152-154, 187-189.

Kuipers, James R., 2000, Hardrock reclamation bonding practices in the Western United States, Report to the National Wildlife Federation, Boulder, CO.

Lazenby, Henry, 2016, “Illinois granted 'superpriority' claims to Peabody's self-bonding obligations", Mining Weekly 23 Aug. 2016, Web, 12 Apr. 2018.

Lewis, Jonathan, and Vivek Melwani, 2006, Treatment of pension plans when an employer is in bankruptcy, Bender's Labor $\&$ Employment Bulletin 6, 163-172.

Merton, Robert C., 1974, On the pricing of corporate debt: The risk structure of interest rates, Journal of Finance 29, 449-470.

Nazzaro, Robin N., 2005, Hardrock mining: BLM needs to better manage financial assurances to guarantee coverage of reclamation costs (Report no. GAO-05-377), Report to the Ranking Minority Member, Committee on Homeland Security and Governmental Affairs, U.S. Senate, United States Government Accountability Office, Washington D.C.

Storrow, Benjamin, 2015, "Alpha Natural Resources and Wyoming regulators announce selfbonding deal in bankruptcy case", Casper Star Tribune 8 Sep. 2015, Web, 1 May 2018. 
Figure B1: Assumed SB vs "reported" SB. This figure displays a scatter plot of selfbonded reclamation liabilities as defined using the self-bonding regulations in Table 1 according to the description in Section 3.1, versus self-bonded reclamation liabilities inferred from firms' annual reports. In particular, the annual report self-bonded reclamation liabilities on the y-axis are defined as a firm's reported reclamation liabilities less reported external bonds (surety bonds, letters of credit, or collateral bonds). The sample starts with 41 firms identified as self-bonding in the project-level sample in 4.2. I remove 12 firms that were either acquired or delisted, six firms that do not report information regarding reclamation liabilities, and three outliers. This leaves 20 firms listed on the TSX or TSXV over the sample period of 2003-2016. The dashed lined represents the line of best fit.

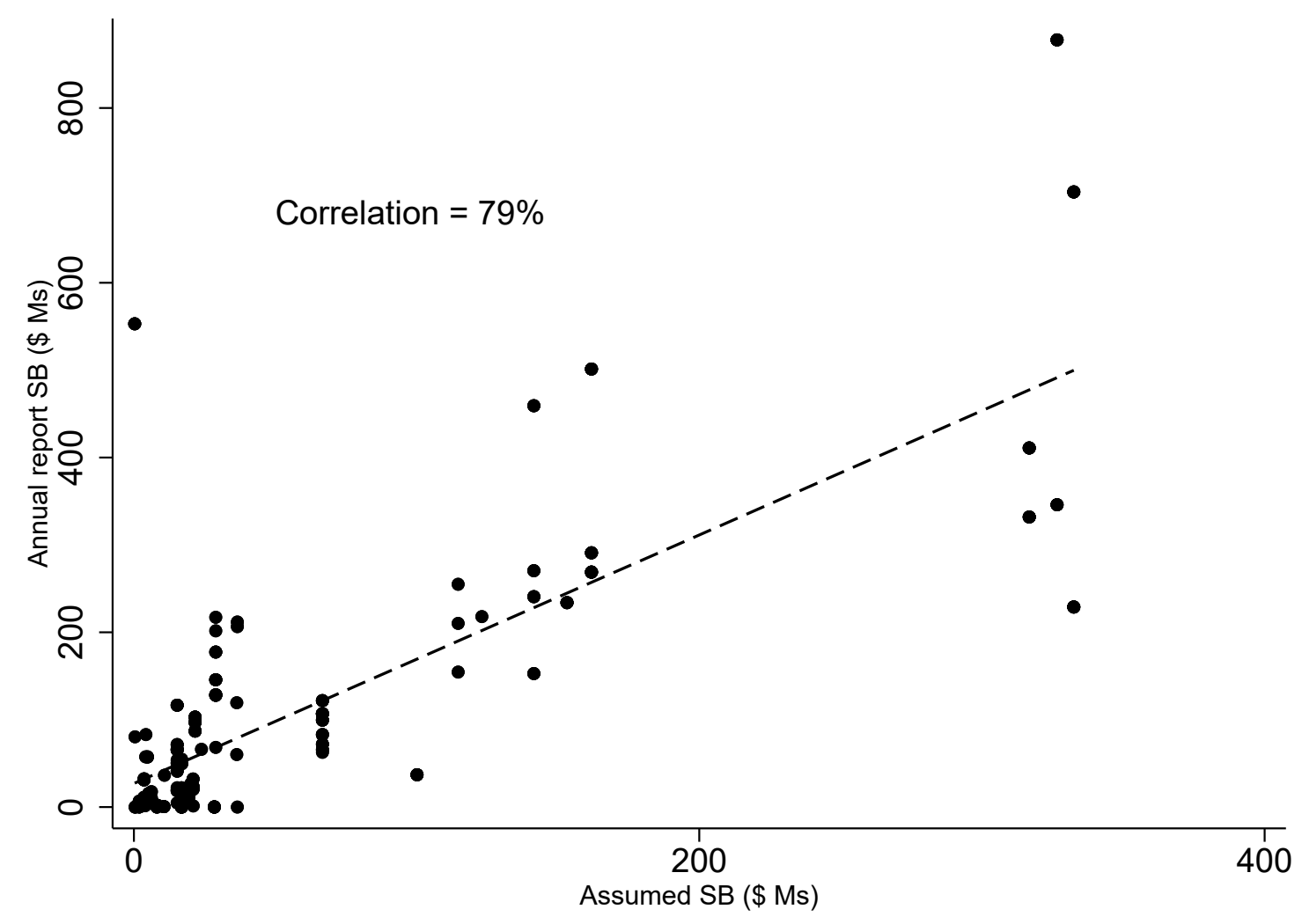


Table B1: The cross-section of traditional debt and the likelihood of acquiring the rights to new positive NPV mining projects. This table reports the results of linear probability models in which the dependent variable is the likelihood a firm acquires the rights to a new positive net present value (NPV+) mining project. The NPV of the mining rights is defined as the value of the NPV estimate in the NI 43-101 technical reports less the cost the acquiring firm paid for the individual mine at acquisition. The sample consists of firms listed on the Toronto Stock Exchange (TSX) or Toronto Stock Exchange Venture (TSXV) and located in Canada over the sample period of 1990 to 2016. In Models (1) and (2), traditional debt is partitioned along two dimensions, effective maturity and secured/unsecured. Model (1) uses Compustat variables DD1 through DD5, which measure the amount of long-term debt due in 1 year through 5 years, to construct the market leverage that is attributable to the respective effective maturities. Model (2) splits traditional debt by whether or not it is secured using the Compustat variable "dm". Model (3) partitions firms' syndicate debt based on above median vs. below median number of lenders. This data comes from Deal Scan. The additional control variables are the same as those in Table 5 of the main text and include accounting variables (defined in Appendix Table 1) constructed using data from Compustat-North America and the data on firms' mining projects provide by Mining Intelligence. Robust standard errors, clustered at the firm level, are reported in parentheses. ${ }^{*}, * *$, and ${ }^{* * *}$ denote significance at the $10 \%, 5 \%$, and $1 \%$ level, respectively.

\begin{tabular}{|c|c|c|c|}
\hline \multirow[t]{2}{*}{ Dependent variable $=$} & \multicolumn{3}{|c|}{$\begin{array}{l}\text { Likelihood of acquiring rights } \\
\text { to projects with eventual } \\
\text { NPV + estimate }\end{array}$} \\
\hline & (1) & $(2)$ & (3) \\
\hline Market leverage $_{\mathrm{DD} 1}$ & $\begin{array}{l}-0.052 \\
(0.038)\end{array}$ & & \\
\hline Market leverage $_{\mathrm{DD} 2}$ & $\begin{array}{c}0.021 \\
(0.105)\end{array}$ & & \\
\hline Market leverage $_{\text {DD3 }}$ & $\begin{array}{c}-0.230^{* *} \\
(0.097)\end{array}$ & & \\
\hline Market leverage $_{\mathrm{DD} 4}$ & $\begin{array}{l}-0.111 \\
(0.152)\end{array}$ & & \\
\hline Market leverage $_{\mathrm{DD} 5+}$ & $\begin{array}{l}-0.010 \\
(0.020)\end{array}$ & & \\
\hline Market leverage $_{\text {Unsecured }}$ & & $\begin{array}{c}-0.035^{* *} \\
(0.017)\end{array}$ & \\
\hline Market leverage $_{\text {Secured }}$ & & $\begin{array}{l}-0.002 \\
(0.033)\end{array}$ & \\
\hline Market leverage ${ }_{\text {Many lenders }}$ & & & $\begin{array}{r}-0.071^{*} \\
(0.042)\end{array}$ \\
\hline Market leverage $_{\mathrm{Few}}$ lenders & & & $\begin{array}{l}-0.007 \\
(0.012)\end{array}$ \\
\hline Market leverage ${ }_{\text {Other }}$ & & & $\begin{array}{l}-0.024 \\
(0.015)\end{array}$ \\
\hline Additional controls & Yes & Yes & Yes \\
\hline Firm FE & Yes & Yes & Yes \\
\hline Year FE & Yes & Yes & Yes \\
\hline Number of firms & 775 & 771 & 73 \\
\hline Observations & 6,758 & 6,654 & 603 \\
\hline$R^{2}$ & 0.165 & 0.168 & 0.300 \\
\hline
\end{tabular}


Table B2: Low-cash liabilities and positive NPV projects. This table reports the results of linear probability models. The dependent variable in Models (1) and (2) is the likelihood a firm acquires the rights to a new positive net present value (NPV+) mining project. The NPV of the mining rights is defined as the value of the NPV estimate in the NI 43-101 technical reports less the cost the acquiring firm paid for the individual mine at acquisition. The sample in Models (1) and (2) consists of firms listed on the Toronto Stock Exchange (TSX) or Toronto Stock Exchange Venture (TSXV) and located in Canada over the sample period of 1990 to 2016. The dependent variable for Models (3) through (6) is the likelihood of beginning construction on a positive net present value $(\mathrm{NPV}+)$ project. The sample is comprised of project-year observations for mining projects from the year the firm publicly discloses the NI 43-101 technical report that includes the initial NPV estimate to the year the firm begins construction on the mine, or the sample period ends, whichever comes first. The sample in Models (3) through (6) consists of firms listed on the Toronto Stock Exchange (TSX) or Toronto Stock Exchange Venture (TSXV) and located in Canada over the sample period of 2003 to 2016. $S B / M V_{\text {Low-cash }(t-1)}$ is the sum of estimated reclamation liabilities of all of a firm's producing mines defined as self-bonded and bonded the year following the firm being in the bottom 25th percentile in terms of cash holdings, divided by the market value of the firm's assets. $E B / M V_{\text {Low-cash }(t-1)}$ is the sum of estimated reclamation liabilities of all of a firm's producing mines defined as externally-bonded (guaranteed with a surety bond, letter of credit, etc.) and bonded the year following the firm being in the bottom 25th percentile in terms of cash holdings, divided by the market value of the firm's assets. $\mathbb{1}_{\mathrm{SB} \geq \mathrm{NPV} \text {, Low-cash }(t-1)}$ is an indicator variable that equals 1 if the sum of estimated reclamation liabilities of all of a firm's producing mines defined as self-bonded and bonded the year following the firm being in the bottom 25th percentile in terms of cash holdings exceeds the initial NPV estimate of the mining project. $\mathbb{1}_{\mathrm{EB} \geq \mathrm{NPV}}$, Low-cash(t-1) is an indicator variable that equals 1 if the sum of estimated reclamation liabilities of all of a firm's producing mines defined as externally-bonded (guaranteed with a surety bond, letter of credit, etc.) and bonded the year following the firm being in the bottom 25 th percentile in terms of cash holdings exceeds the initial NPV estimate of the mining project. $\mathbb{1}_{\mathrm{TD} \geq \mathrm{NPV}}$ is an indicator variable that equals 1 if the firm's traditional debt exceeds the initial NPV estimate of the mining project. The data on estimated reclamation liabilities were hand-collected from firms' public disclosures. Self-bonded and externally-bonded mines are classified using the self-bonding regulations in Table 1 according to the description in Section 3.1. The additional control variables in Models (1) and (2) are the same as those in Table 5, Model (5) of the main text and the additional control variables in Models (3) through (6) are the same as those in Table 6, Model (2). The accounting variables (defined in Appendix Table 1) are constructed using data from Compustat - North America and the data on firms' mining projects is provided by Mining Intelligence. Robust standard errors, clustered at the firm level, are reported in parentheses. ${ }^{*}, * *$, and ${ }^{* * *}$ denote significance at the $10 \%, 5 \%$, and $1 \%$ level, respectively.

\begin{tabular}{|c|c|c|c|c|c|c|}
\hline \multirow[t]{2}{*}{ Dependent variable $=$} & \multicolumn{2}{|c|}{ Acquire rights } & \multicolumn{4}{|c|}{ Begin construction } \\
\hline & $(1)$ & $(2)$ & $(3)$ & $(4)$ & $(5)$ & (6) \\
\hline $\mathrm{SB} / \mathrm{MV}_{\text {Low-cash }(t-1)}$ & $\begin{array}{c}-0.022^{* * *} \\
(0.008)\end{array}$ & $\begin{array}{c}-0.023^{* * *} \\
(0.008)\end{array}$ & $\begin{array}{c}-0.046^{* * *} \\
(0.014)\end{array}$ & $\begin{array}{c}-0.055^{* * *} \\
(0.014)\end{array}$ & & \\
\hline $\mathrm{EB} / \mathrm{MV}_{\mathrm{Low}-\operatorname{cash}(t-1)}$ & $\begin{array}{l}0.001 \\
(0.001)\end{array}$ & $\begin{array}{l}0.001 \\
(0.001)\end{array}$ & $\begin{array}{c}0.006 \\
(0.067)\end{array}$ & $\begin{array}{l}-0.020 \\
(0.068)\end{array}$ & & \\
\hline Market leverage & $\begin{array}{l}-0.014 \\
(0.015)\end{array}$ & $\begin{array}{l}-0.026 \\
(0.016)\end{array}$ & $\begin{array}{c}0.011 \\
(0.058)\end{array}$ & $\begin{array}{l}-0.005 \\
(0.056)\end{array}$ & & \\
\hline $\mathbb{1}_{\mathrm{SB} \geq \mathrm{NPV}, \operatorname{Low}-\operatorname{cash}(t-1)}$ & & & & & $\begin{array}{c}-0.217^{* *} \\
(0.093)\end{array}$ & $\begin{array}{c}-0.280^{* * *} \\
(0.097)\end{array}$ \\
\hline $\mathbb{1}_{\mathrm{EB} \geq \mathrm{NPV}, \text { Low-cash }(t-1)}$ & & & & & $\begin{array}{l}-0.024 \\
(0,030)\end{array}$ & $\begin{array}{l}-0.091 \\
(0.065)\end{array}$ \\
\hline $\mathbb{1}_{\mathrm{TD} \geq \mathrm{NPV}}$ & & & & & $\begin{array}{l}-0.015 \\
(0.069)\end{array}$ & $\begin{array}{l}-0.036 \\
(0.072)\end{array}$ \\
\hline Additional controls & No & Yes & No & Yes & No & Yes \\
\hline Firm FE & Yes & Yes & Yes & Yes & Yes & Yes \\
\hline Year FE & Yes & Yes & Yes & Yes & Yes & Yes \\
\hline Number of firms & 790 & 775 & 177 & 174 & 177 & 174 \\
\hline Observations & 7,083 & 6,747 & 838 & 822 & 838 & 822 \\
\hline$R^{2}$ & 0.128 & 0.151 & 0.289 & 0.299 & 0.290 & 0.302 \\
\hline
\end{tabular}


Table B3: Applying U.S. 30 C.F.R. $\$ 800.23$ standards to U.S. self-bonded reclamation liabilities. This table reports the results of linear probability models. The dependent variable in Models (1) and (2) is the likelihood a firm acquires the rights to a new positive net present value (NPV+) mining project. The NPV of the mining rights is defined as the value of the NPV estimate in the NI 43-101 technical reports less the cost the acquiring firm paid for the individual mine at acquisition. The sample in Models (1) and (2) consists of firms listed on the Toronto Stock Exchange (TSX) or Toronto Stock Exchange Venture (TSXV) and located in Canada over the sample period of 1990 to 2016. The dependent variable for Models (3) through (6) is the likelihood of beginning construction on a positive net present value (NPV+) project. The sample is comprised of project-year observations for mining projects from the year the firm publicly discloses the NI 43-101 technical report that includes the initial NPV estimate to the year the firm begins construction on the mine, or the sample period ends, whichever comes first. The sample in Models (3) through (6) consists of firms listed on the Toronto Stock Exchange (TSX) or Toronto Stock Exchange Venture (TSXV) and located in Canada over the sample period of 2003 to 2016. $S B / M V_{\S 800.23}$ is the sum of estimated reclamation liabilities of all of a firm's producing mines defined as self-bonded and that meet the standards set by U.S. 30 C.F.R. $\$ 800.23$, divided by the market value of the firm's assets. $E B / M V_{\S 800.23}$ is the sum of estimated reclamation liabilities of all of a firm's producing mines defined as externally-bonded (guaranteed with a surety bond, letter of credit, etc.) and those that do not meet the standards set by U.S. 30 C.F.R. $\S 800.23$, divided by the market value of the firm's assets. $\mathbb{1}_{\mathrm{SB} \geq \mathrm{NPV}}, \S 800.23$ is an indicator variable that equals 1 if the sum of estimated reclamation liabilities of all of a firm's producing mines defined as self-bonded and that meet the standards set by U.S. 30 C.F.R. $\$ 800.23$ exceeds the initial NPV estimate of the mining project. $\mathbb{1}_{\mathrm{EB} \geq \mathrm{NPV}}, \S 800.23$ is an indicator variable that equals 1 if the sum of estimated reclamation liabilities of all of a firm's producing mines defined as externally-bonded (guaranteed with a surety bond, letter of credit, etc.) and that those that do not meet the standards set by U.S. 30 C.F.R. $\S 800.23$ exceeds the initial NPV estimate of the mining project. $\mathbb{1}_{\mathrm{TD} \geq \mathrm{NPV}}$ is an indicator variable that equals 1 if the firm's traditional debt exceeds the initial NPV estimate of the mining project. The data on estimated reclamation liabilities were hand-collected from firms' public disclosures. Self-bonded and externally-bonded mines are classified using the self-bonding regulations in Table 1 according to the description in Section 3.1. The additional control variables in Models (1) and (2) are the same as those in Table 5, Model (5) of the main text and the additional control variables in Models (3) through (6) are the same as those in Table 6, Model (2). The accounting variables (defined in Appendix Table 1) are constructed using data from Compustat-North America and the data on firms' mining projects is provided by Mining Intelligence. Robust standard errors, clustered at the firm level, are reported in parentheses. ${ }^{*}, *$, and $* * *$ denote significance at the $10 \%, 5 \%$, and $1 \%$ level, respectively.

\begin{tabular}{|c|c|c|c|c|c|c|}
\hline \multirow[t]{2}{*}{ Dependent variable $=$} & \multicolumn{2}{|c|}{ Acquire rights } & \multicolumn{4}{|c|}{ Begin construction } \\
\hline & (1) & $(2)$ & (3) & (4) & (5) & (6) \\
\hline $\mathrm{SB} / \mathrm{MV}_{\$ 800.23}$ & $\begin{array}{c}-0.022^{* * *} \\
(0.008)\end{array}$ & $\begin{array}{c}-0.024^{* * *} \\
(0.006)\end{array}$ & $\begin{array}{c}-0.046^{* * *} \\
(0.014)\end{array}$ & $\begin{array}{c}-0.055^{* * *} \\
(0.014)\end{array}$ & & \\
\hline $\mathrm{EB} / \mathrm{MV}_{\S 800.23}$ & $\begin{array}{c}0.001 \\
(0.001)\end{array}$ & $\begin{array}{c}0.001 \\
(0.001)\end{array}$ & $\begin{array}{c}0.017 \\
(0.054)\end{array}$ & $\begin{array}{l}-0.003 \\
(0.056)\end{array}$ & & \\
\hline Market leverage & $\begin{array}{l}-0.014 \\
(0.015)\end{array}$ & $\begin{array}{l}-0.026 \\
(0.016)\end{array}$ & $\begin{array}{c}0.010 \\
(0.058)\end{array}$ & $\begin{array}{l}-0.007 \\
(0.056)\end{array}$ & & \\
\hline $\mathbb{1}_{\mathrm{SB} \geq \mathrm{NPV}, \S 800.23}$ & & & & & $\begin{array}{l}-0.212^{*} \\
(0.113)\end{array}$ & $\begin{array}{c}-0.253^{* *} \\
(0.117)\end{array}$ \\
\hline $\mathbb{1}_{\mathrm{EB} \geq \mathrm{NPV}, \S 800.23}$ & & & & & $\begin{array}{l}-0.017 \\
(0.071)\end{array}$ & $\begin{array}{l}-0.068 \\
(0.080)\end{array}$ \\
\hline $\mathbb{1}_{\mathrm{TD} \geq \mathrm{NPV}}$ & & & & & $\begin{array}{l}-0.015 \\
(0.066)\end{array}$ & $\begin{array}{l}-0.036 \\
(0.072)\end{array}$ \\
\hline Additional controls & No & Yes & No & Yes & No & Yes \\
\hline Firm FE & Yes & Yes & Yes & Yes & Yes & Yes \\
\hline Year FE & Yes & Yes & Yes & Yes & Yes & Yes \\
\hline Number of firms & 790 & 775 & 177 & 174 & 177 & 174 \\
\hline Observations & 7,083 & 6,747 & 838 & 822 & 838 & 822 \\
\hline$R^{2}$ & 0.128 & 0.151 & 0.289 & 0.299 & 0.290 & 0.302 \\
\hline
\end{tabular}


Table B4: Reclamation liabilities and investment in the U.S. This table reports the results of linear regression models in which the dependent variable of interest is either capital expenditures (as a percentage of a firm's total book assets) or the incidence of a new mine (Model (7)). In Models (1) through (4), the sample consists of mining firms incorporated in the United States over the sample period of 1992 to 2016 that self-disclose reclamation liabilities in their annual reports. $S B / M V$ is total amount of disclosed self-bonded reclamation liabilities divided by the market value of the firm's assets. $E B / M V$ is total amount of disclosed externally-bonded (guaranteed with a surety bond, letter of credit, etc.) reclamation liabilities divided by the market value of the firm's assets. $\mathbb{1}_{\mathrm{SB} \geq 0}$ is an indicator variable that equals 1 if the firm has a positive amount of self-bonds. In Models (5) through (7), I use data from the Mine Safety and Health Administration (MSHA) on the location and status of a firm's mines to calculate the number of mines defined as self-bonded and externally-bonded using the self-bonding regulations in Table 1 according to the description in Section 3.1. Accounting variables are constructed using data from Compustat-North America. Robust standard errors, clustered at the firm level, are reported in parentheses. ${ }^{*}, * *$, and ${ }^{* * *}$ denote significance at the $10 \%$, $5 \%$, and $1 \%$ level, respectively.

\begin{tabular}{|c|c|c|c|c|c|c|c|}
\hline \multirow[t]{2}{*}{ Dependent variable $=$} & \multicolumn{6}{|c|}{ Capital expenditures } & \multirow{2}{*}{$\frac{\text { New mine }}{(7)}$} \\
\hline & $(1)$ & $(2)$ & $(3)$ & $(4)$ & $(5)$ & $(6)$ & \\
\hline $\begin{array}{l}\mathrm{SB} / \mathrm{MV} \\
\mathrm{EB} / \mathrm{MV}\end{array}$ & $\begin{array}{l}-0.080^{*} \\
(0.040) \\
-0.016 \\
(0.014)\end{array}$ & $\begin{array}{c}-0.112^{* *} \\
(0.043) \\
-0.011 \\
(0.008)\end{array}$ & & & & & \\
\hline $\mathbb{1}_{\mathrm{SB} \geq 0}$ & & & $\begin{array}{c}-0.016^{* * *} \\
(0.004)\end{array}$ & $\begin{array}{c}-0.022^{* * *} \\
(0.008)\end{array}$ & & & \\
\hline \# of self-bonded mines & & & & & $\begin{array}{c}-0.003^{*} \\
(0.002)\end{array}$ & $\begin{array}{c}-0.003^{*} \\
(0.001)\end{array}$ & $\begin{array}{c}-0.015^{* *} \\
(0.006)\end{array}$ \\
\hline \# of externally-bonded mines & & & & & $\begin{array}{c}0.003^{*} \\
(0.001)\end{array}$ & $\begin{array}{c}0.003^{* *} \\
(0.001)\end{array}$ & $\begin{array}{c}0.016^{* * *} \\
(0.006)\end{array}$ \\
\hline Market leverage & $\begin{array}{l}-0.037 \\
(0.028)\end{array}$ & $\begin{array}{c}-0.002 \\
(0.032)\end{array}$ & $\begin{array}{l}-0.040 \\
(0.026)\end{array}$ & $\begin{array}{l}-0.015 \\
(0.028)\end{array}$ & $\begin{array}{c}-0.026^{* *} \\
(0.012)\end{array}$ & $\begin{array}{c}-0.009 \\
(0.012)\end{array}$ & \\
\hline Log of book assets & & $\begin{array}{l}0.011 \\
(0.016)\end{array}$ & & $\begin{array}{c}0.010 \\
(0.015)\end{array}$ & & $\begin{array}{l}-0.004 \\
(0.003)\end{array}$ & \\
\hline Cash & & $\begin{array}{c}-0.080^{* *} \\
(0.036)\end{array}$ & & $\begin{array}{l}-0.035 \\
(0.037)\end{array}$ & & $\begin{array}{c}-0.092^{* * *} \\
(0.017)\end{array}$ & \\
\hline $\mathrm{ROA}$ & & $\begin{array}{c}-0.043^{*} \\
(0.024)\end{array}$ & & $\begin{array}{c}-0.040^{*} \\
(0.023)\end{array}$ & & $\begin{array}{c}0.043 \\
(0.027)\end{array}$ & \\
\hline Tobin's $Q$ & & $\begin{array}{c}0.028^{* * * *} \\
(0.006)\end{array}$ & & $\begin{array}{c}0.024^{* * *} * \\
(0.005)\end{array}$ & & $\begin{array}{c}0.015^{* * *} \\
(0.005)\end{array}$ & \\
\hline Log of firm age & & $\begin{array}{l}-0.001 \\
(0.001)\end{array}$ & & $\begin{array}{l}-0.000 \\
(0.001)\end{array}$ & & $\begin{array}{c}0.001 \\
(0.005)\end{array}$ & \\
\hline Firm fixed effects & Yes & Yes & Yes & Yes & Yes & $\mathrm{Ye}$ & Yes \\
\hline $\begin{array}{l}\text { Year fixed effects } \\
\text { Data used }\end{array}$ & $\begin{array}{l}\text { Yes } \\
10-k\end{array}$ & Yes & Yes & Yes & $\begin{array}{c}\text { Yes } \\
\text { MSHA }\end{array}$ & Yes & Yes \\
\hline & & & & & & & \\
\hline $\begin{array}{l}\text { Number of firms } \\
\text { Observations }\end{array}$ & $\begin{array}{c}39 \\
338\end{array}$ & $\begin{array}{c}39 \\
338\end{array}$ & $\begin{array}{c}42 \\
359\end{array}$ & $\begin{array}{c}42 \\
359\end{array}$ & $\begin{array}{c}120 \\
1,453\end{array}$ & $\begin{array}{c}120 \\
1,453\end{array}$ & $\begin{array}{c}4,983 \\
33,876\end{array}$ \\
\hline$R^{2}$ & 0.621 & 0.680 & 0.629 & 0.682 & 0.559 & 0.585 & 0.238 \\
\hline
\end{tabular}


Table B5: Firm liabilities and the likelihood of beginning construction on positive NPV projects. This table reports the results of linear probability models in which the dependent variable is the likelihood of beginning construction on a positive net present value (NPV+) project. The sample is comprised of project-year observations for mining projects from the year the firm publicly discloses the NI 43-101 technical report that includes the initial NPV estimate to the year the firm begins construction on the mine, or the sample period ends, whichever comes first. The sample consists of firms listed on the Toronto Stock Exchange (TSX) or Toronto Stock Exchange Venture (TSXV) and located in Canada over the sample period of 2003 to 2016. $S B / M V$ is the sum of estimated reclamation liabilities of all of a firm's producing mines defined as self-bonded divided by the market value of the firm's assets. $E B / M V$ is the sum of estimated reclamation liabilities of all of a firm's producing mines defined as externally-bonded (guaranteed with a surety bond, letter of credit, etc.) divided by the market value of the firm's assets. $\mathbb{1}_{\mathrm{SB}} \geq \mathrm{NPV}$ is an indicator variable that equals 1 if the sum of estimated reclamation liabilities of all of a firm's producing mines defined as self-bonded exceeds the initial NPV estimate of the mining project. $\mathbb{1}_{\mathrm{EB}}>\mathrm{NPV}$ is an indicator variable that equals 1 if the sum of estimated reclamation liabilities of all of a firm's producing mines defined as externally-bonded (guaranteed with a surety bond, letter of credit, etc.) exceeds the initial NPV estimate of the mining project. $\mathbb{1}_{\mathrm{TD}} \geq \mathrm{NPV}$ is an indicator variable that equals 1 if the firm's traditional debt exceeds the initial NPV estimate of the mining project. The data on estimated reclamation liabilities were hand-collected from firms' public disclosures. Self-bonded and externally-bonded mines are classified using the self-bonding regulations in Table 1 according to the description in Section 3.1. The additional controls are the same as from Table 6, Model (2) in Panels A and B. Accounting variables (defined in Appendix Table 1) are constructed using data from Compustat-North America, the project data were provide by Mining Intelligence. Robust standard errors, clustered at the firm level, are reported in parentheses. ${ }^{*}, * *$, and $* * *$ denote significance at the $10 \%, 5 \%$, and $1 \%$ level, respectively.

Dependent variable $=$

Likelihood of beginning construction on an NPV+ project

\begin{tabular}{|c|c|c|c|c|c|c|c|c|}
\hline & (1) & $(2)$ & $(3)$ & $(4)$ & $(5)$ & (6) & $(7)$ & $(8)$ \\
\hline $\mathrm{SB} / \mathrm{MV}$ & $\begin{array}{c}-0.053^{* * *} \\
(0.013)\end{array}$ & $\begin{array}{c}-0.053^{* * *} \\
(0.013)\end{array}$ & $\begin{array}{c}-0.054^{* * *} \\
(0.014)\end{array}$ & $\begin{array}{c}-0.157 \\
(0.217)\end{array}$ & & & & \\
\hline $\mathrm{EB} / \mathrm{MV}$ & $\begin{array}{c}-0.010 \\
(0.059)\end{array}$ & $\begin{array}{c}0.002 \\
(0.062)\end{array}$ & $\begin{array}{c}-0.007 \\
(0.060)\end{array}$ & $\begin{array}{c}0.013 \\
(0.092)\end{array}$ & & & & \\
\hline Market leverage & $\begin{array}{l}-0.015 \\
(0.052)\end{array}$ & $\begin{array}{l}-0.031 \\
(0.051)\end{array}$ & $\begin{array}{l}-0.003 \\
(0.054)\end{array}$ & $\begin{array}{c}-0.026 \\
(0.079)\end{array}$ & & & & \\
\hline $\mathbb{1}_{\mathrm{SB} \geq \mathrm{NPV}}$ & & & & & $\begin{array}{c}-0.445^{* * *} \\
(0.135)\end{array}$ & $\begin{array}{c}-0.298^{* *} \\
(0.117)\end{array}$ & $\begin{array}{c}-0.230^{* *} \\
(0.108)\end{array}$ & $\begin{array}{c}-0.206^{* *} \\
(0.099)\end{array}$ \\
\hline $\mathbb{1}_{\mathrm{EB} \geq \mathrm{NPV}}$ & & & & & $\begin{array}{c}0.101 \\
(0.109)\end{array}$ & $\begin{array}{l}-0.082 \\
(0.066)\end{array}$ & $\begin{array}{c}0.013 \\
(0.090)\end{array}$ & $\begin{array}{c}-0.026 \\
(0.090)\end{array}$ \\
\hline $\mathbb{1}_{\mathrm{TD} \geq \mathrm{NPV}}$ & & & & & $\begin{array}{l}-0.060 \\
(0.075)\end{array}$ & $\begin{array}{c}-0.076 \\
(0.072)\end{array}$ & $\begin{array}{c}-0.026 \\
(0.069)\end{array}$ & $\begin{array}{c}-0.006 \\
(0.074)\end{array}$ \\
\hline Additional Controls & Yes & Yes & Yes & Yes & Yes & Yes & Yes & Yes \\
\hline Firm FE & Yes & Yes & Yes & Yes & Yes & Yes & Yes & Yes \\
\hline Year FE & Yes & Yes & Yes & No & Yes & Yes & Yes & No \\
\hline State/Province FE & Yes & No & No & No & Yes & No & No & No \\
\hline Country FE & No & Yes & No & No & No & Yes & No & No \\
\hline Mine type FE & No & No & Yes & No & No & No & Yes & No \\
\hline Primary mineral $\times$ year FE & No & No & No & Yes & No & No & No & Yes \\
\hline Number of firms & 170 & 173 & 174 & 161 & 170 & 173 & 174 & 161 \\
\hline Observations & 809 & 820 & 822 & 737 & 813 & 824 & 826 & 741 \\
\hline$R^{2}$ & 0.371 & 0.330 & 0.315 & 0.362 & 0.373 & 0.334 & 0.314 & 0.362 \\
\hline
\end{tabular}


Table B6: Firm liability ratios and the likelihood of permitting a positive NPV projects. This table reports the results of linear probability models in which the dependent variable is the likelihood of permitting a positive net present value (NPV+) project. The sample is comprised of project-year observations for mining projects from the year the firm publicly discloses the NI 43-101 technical report that includes the initial NPV estimate to the year the firm begins construction on the mine, or the sample period ends, whichever comes first. The sample consists of firms listed on the Toronto Stock Exchange (TSX) or Toronto Stock Exchange Venture (TSXV) and located in Canada over the sample period of 2003 to 2016. $S B / M V$ is the sum of estimated reclamation liabilities of all of a firm's producing mines defined as self-bonded divided by the market value of the firm's assets. $E B / M V$ is the sum of estimated reclamation liabilities of all of a firm's producing mines defined as externally-bonded (guaranteed with a surety bond, letter of credit, etc.) divided by the market value of the firm's assets. $\mathbb{1}_{\mathrm{SB} \geq \mathrm{NPV}}$ is an indicator variable that equals 1 if the sum of estimated reclamation liabilities of all of a firm's producing mines defined as self-bonded exceeds the initial NPV estimate of the mining project. $\mathbb{1}_{\mathrm{EB}>\mathrm{NPV}}$ is an indicator variable that equals 1 if the sum of estimated reclamation liabilities of all of a firm's producing mines defined as externally-bonded (guaranteed with a surety bond, letter of credit, etc.) exceeds the initial NPV estimate of the mining project. $\mathbb{1}_{\mathrm{TD}}>\mathrm{NPV}$ is an indicator variable that equals 1 if the firm's traditional debt exceeds the initial NPV estimate of the mining project. The data on estimated reclamation liabilities were hand-collected from firms' public disclosures. Self-bonded and externally-bonded mines are classified using the self-bonding regulations in Table 1 according to the description in Section 3.1. Accounting variables (defined in Appendix Table 1) are constructed using data from Compustat-North America, the project data were provide by Mining Intelligence and futures data is from Bloomberg. Robust standard errors, clustered at the firm level, are reported in parentheses. ${ }^{*}, * *$, and ${ }^{* * *}$ denote significance at the $10 \%, 5 \%$, and $1 \%$ level, respectively.

\begin{tabular}{|c|c|c|c|c|c|}
\hline \multicolumn{6}{|l|}{ Panel A: Liability ratios } \\
\hline \multirow[t]{2}{*}{ Dependent variable $=$} & \multicolumn{5}{|c|}{ Likelihood of permitting an NPV+ project } \\
\hline & $(1)$ & $(2)$ & $(3)$ & $(4)$ & $(5)$ \\
\hline $\mathrm{SB} / \mathrm{MV}$ & $\begin{array}{l}-0.008 \\
(0.006)\end{array}$ & $\begin{array}{l}-0.005 \\
(0.006)\end{array}$ & $\begin{array}{l}-0.006 \\
(0.006)\end{array}$ & $\begin{array}{c}0.000 \\
(0.008)\end{array}$ & $\begin{array}{c}0.008 \\
(0.012)\end{array}$ \\
\hline $\mathrm{EB} / \mathrm{MV}$ & $\begin{array}{c}0.019 \\
(0.032)\end{array}$ & $\begin{array}{c}0.013 \\
(0.035)\end{array}$ & $\begin{array}{l}0.038 \\
(0.060)\end{array}$ & $\begin{array}{l}0.019 \\
(0.055)\end{array}$ & $\begin{array}{c}0.017 \\
(0.058)\end{array}$ \\
\hline Market leverage & $\begin{array}{l}-0.034 \\
(0.046)\end{array}$ & $\begin{array}{l}-0.020 \\
(0.034)\end{array}$ & $\begin{array}{l}-0.043 \\
(0.032)\end{array}$ & $\begin{array}{l}-0.038 \\
(0.029)\end{array}$ & $\begin{array}{l}-0.033 \\
(0.032)\end{array}$ \\
\hline Log of book assets & & $\begin{array}{c}0.003 \\
(0.009)\end{array}$ & $\begin{array}{l}-0.001 \\
(0.009)\end{array}$ & $\begin{array}{c}0.000 \\
(0.009)\end{array}$ & $\begin{array}{c}0.002 \\
(0.011)\end{array}$ \\
\hline Cash & & $\begin{array}{l}-0.004 \\
(0.025)\end{array}$ & $\begin{array}{l}-0.016 \\
(0.032)\end{array}$ & $\begin{array}{l}-0.018 \\
(0.031)\end{array}$ & $\begin{array}{l}-0.019 \\
(0.035)\end{array}$ \\
\hline ROA & & $\begin{array}{l}0.000 \\
(0.005)\end{array}$ & $\begin{array}{l}-0.000 \\
(0.005)\end{array}$ & $\begin{array}{l}-0.002 \\
(0.005)\end{array}$ & $\begin{array}{l}-0.003 \\
(0.006)\end{array}$ \\
\hline Tobin's $Q$ & & $\begin{array}{c}0.000 \\
(0.002)\end{array}$ & $\begin{array}{l}-0.001 \\
(0.002)\end{array}$ & $\begin{array}{l}-0.002 \\
(0.002)\end{array}$ & $\begin{array}{l}-0.002 \\
(0.003)\end{array}$ \\
\hline lnage & & $\begin{array}{l}-0.060 \\
(0.039)\end{array}$ & $\begin{array}{l}-0.036 \\
(0.041)\end{array}$ & $\begin{array}{l}-0.043 \\
(0.041)\end{array}$ & $\begin{array}{l}-0.050 \\
(0.040)\end{array}$ \\
\hline Project NPV ( $\$ 100 \mathrm{Ms})$ & & $\begin{array}{l}-0.002 \\
(0.002)\end{array}$ & $\begin{array}{l}-0.002 \\
(0.002)\end{array}$ & $\begin{array}{l}-0.002 \\
(0.003)\end{array}$ & $\begin{array}{l}-0.003 \\
(0.003)\end{array}$ \\
\hline Project Capital Costs $(\$ 100 \mathrm{Ms})$ & & $\begin{array}{l}0.001 \\
(0.003)\end{array}$ & $\begin{array}{l}0.001 \\
(0.003)\end{array}$ & $\begin{array}{l}0.001 \\
(0.003)\end{array}$ & $\begin{array}{l}0.002 \\
(0.003)\end{array}$ \\
\hline Expected mine life & & $\begin{array}{c}0.003^{* *} \\
(0.002)\end{array}$ & $\begin{array}{l}0.003^{*} \\
(0.002)\end{array}$ & $\begin{array}{l}0.004^{*} \\
(0.003)\end{array}$ & $\begin{array}{l}0.005 \\
(0.003)\end{array}$ \\
\hline Total NPV of alternative projects $(\$ 100 \mathrm{Ms})$ & & $\begin{array}{l}-0.005 \\
(0.004)\end{array}$ & $\begin{array}{l}-0.004 \\
(0.004)\end{array}$ & $\begin{array}{l}-0.003 \\
(0.004)\end{array}$ & $\begin{array}{l}-0.004 \\
(0.005)\end{array}$ \\
\hline Start alternative NPV+ project & & $\begin{array}{c}0.072 \\
(0.048)\end{array}$ & $\begin{array}{c}0.079 \\
(0.050)\end{array}$ & $\begin{array}{c}0.081 \\
(0.051)\end{array}$ & $\begin{array}{c}0.084 \\
(0.053)\end{array}$ \\
\hline Primary mineral price $(\% \mathrm{ch})$. & & & $\begin{array}{l}0.003 \\
(0.024)\end{array}$ & & \\
\hline Futures price & & & & $\begin{array}{l}0.006^{*} \\
(0.004)\end{array}$ & $\begin{array}{l}0.010^{*} \\
(0.006)\end{array}$ \\
\hline Options-implied volatility & & & & & $\begin{array}{l}-0.080 \\
(0.053)\end{array}$ \\
\hline Controls for projects in each stage & Yes & Yes & Yes & Yes & Yes \\
\hline Firm FE & Yes & Yes & Yes & Yes & Yes \\
\hline Year FE & Yes & Yes & Yes & Yes & Yes \\
\hline Primary mineral FE & No & No & No & Yes & Yes \\
\hline Number of firms & 177 & 174 & 146 & 144 & 129 \\
\hline Observations & 838 & 822 & 694 & 681 & 606 \\
\hline$R^{2}$ & 0.198 & 0.250 & 0.263 & 0.272 & 0.278 \\
\hline
\end{tabular}


Table IA6-Continued

\begin{tabular}{|c|c|c|c|c|c|}
\hline \multirow[t]{2}{*}{ Dependent variable $=$} & \multicolumn{5}{|c|}{ Likelihood of permitting an NPV+ project } \\
\hline & $(1)$ & $(2)$ & $(3)$ & $(4)$ & $(5)$ \\
\hline $\mathbb{1}_{\mathrm{SB} \geq \mathrm{NPV}}$ & $\begin{array}{l}-0.044 \\
(0.050)\end{array}$ & $\begin{array}{l}-0.009 \\
(0.102)\end{array}$ & $\begin{array}{l}-0.006 \\
(0.103)\end{array}$ & $\begin{array}{c}0.013 \\
(0.112)\end{array}$ & $\begin{array}{c}0.055 \\
(0.148)\end{array}$ \\
\hline $\mathbb{1}_{\mathrm{EB} \geq \mathrm{NPV}}$ & $\begin{array}{c}0.006 \\
(0.048)\end{array}$ & $\begin{array}{c}0.021 \\
(0.055)\end{array}$ & $\begin{array}{c}0.021 \\
(0.058)\end{array}$ & $\begin{array}{c}0.045 \\
(0.063)\end{array}$ & $\begin{array}{c}0.052 \\
(0.069)\end{array}$ \\
\hline $\mathbb{1}_{\mathrm{TD} \geq \mathrm{NPV}}$ & $\begin{array}{l}-0.042 \\
(0.036)\end{array}$ & $\begin{array}{l}-0.039 \\
(0.037)\end{array}$ & $\begin{array}{l}-0.036 \\
(0.037)\end{array}$ & $\begin{array}{l}-0.038 \\
(0.039)\end{array}$ & $\begin{array}{r}-0.043 \\
(0.042)\end{array}$ \\
\hline Log of book assets & & $\begin{array}{c}0.005 \\
0.005 \\
(0.010)\end{array}$ & $\begin{array}{l}-0.000 \\
(0.010)\end{array}$ & $\begin{array}{c}0.001 \\
(0.010)\end{array}$ & $\begin{array}{c}0.004 \\
(0.011)\end{array}$ \\
\hline Cash & & $\begin{array}{l}-0.004 \\
(0.024)\end{array}$ & $\begin{array}{l}-0.014 \\
(0.031)\end{array}$ & $\begin{array}{l}-0.016 \\
(0.030)\end{array}$ & $\begin{array}{l}-0.014 \\
(0.034)\end{array}$ \\
\hline ROA & & $\begin{array}{c}0.001 \\
(0.005)\end{array}$ & $\begin{array}{c}0.001 \\
(0.005)\end{array}$ & $\begin{array}{l}-0.001 \\
(0.005)\end{array}$ & $\begin{array}{l}-0.003 \\
(0.005)\end{array}$ \\
\hline Tobin's $Q$ & & $\begin{array}{c}0.001 \\
(0.002)\end{array}$ & $\begin{array}{l}-0.001 \\
(0.002)\end{array}$ & $\begin{array}{l}-0.001 \\
(0.002)\end{array}$ & $\begin{array}{l}-0.002 \\
(0.003)\end{array}$ \\
\hline Log of Age & & $\begin{array}{l}-0.060 \\
(0.040)\end{array}$ & $\begin{array}{l}-0.038 \\
(0.043)\end{array}$ & $\begin{array}{l}-0.043 \\
(0.043)\end{array}$ & $\begin{array}{l}-0.051 \\
(0.042)\end{array}$ \\
\hline Project NPV ( $\$ 100 \mathrm{Ms})$ & & $\begin{array}{l}-0.001 \\
(0.003)\end{array}$ & $\begin{array}{l}-0.001 \\
(0.004)\end{array}$ & $\begin{array}{l}-0.001 \\
(0.004)\end{array}$ & $\begin{array}{l}-0.000 \\
(0.004)\end{array}$ \\
\hline Project Capital Costs $(\$ 100 \mathrm{Ms})$ & & $\begin{array}{c}0.001 \\
(0.004)\end{array}$ & $\begin{array}{c}0.001 \\
(0.004)\end{array}$ & $\begin{array}{c}0.001 \\
(0.004)\end{array}$ & $\begin{array}{c}0.001 \\
(0.004)\end{array}$ \\
\hline Expected mine life & & $\begin{array}{l}0.003^{*} \\
(0.002)\end{array}$ & $\begin{array}{l}0.003^{*} \\
(0.002)\end{array}$ & $\begin{array}{l}0.005^{*} \\
(0.003)\end{array}$ & $\begin{array}{c}0.006^{* *} \\
(0.003)\end{array}$ \\
\hline Total NPV of alternative projects $(\$ 100 \mathrm{Ms})$ & & $\begin{array}{l}-0.004 \\
(0.004)\end{array}$ & $\begin{array}{l}-0.003 \\
(0.004)\end{array}$ & $\begin{array}{l}-0.002 \\
(0.004)\end{array}$ & $\begin{array}{l}-0.002 \\
(0.004)\end{array}$ \\
\hline Start alternative NPV+ project & & $\begin{array}{l}0.076 \\
(0.047)\end{array}$ & $\begin{array}{l}0.082^{*} \\
(0.049)\end{array}$ & $\begin{array}{c}0.083 \\
(0.051)\end{array}$ & $\begin{array}{c}0.083 \\
(0.053)\end{array}$ \\
\hline Primary mineral price ( $\%$ ch. $)$ & & & $\begin{array}{c}0.005 \\
(0.025)\end{array}$ & & \\
\hline Futures price & & & & $\begin{array}{l}0.007^{*} \\
(0.004)\end{array}$ & $\begin{array}{l}0.010^{*} \\
(0.005)\end{array}$ \\
\hline Options-implied volatility & & & & & $\begin{array}{l}-0.083 \\
(0.053)\end{array}$ \\
\hline Controls for projects in each stage & Yes & Yes & Yes & Yes & Yes \\
\hline Firm FE & Yes & Yes & Yes & Yes & Yes \\
\hline Year FE & Yes & Yes & Yes & Yes & Yes \\
\hline Primary mineral FE & No & No & No & Yes & Yes \\
\hline Number of firms & 177 & 174 & 146 & 144 & 129 \\
\hline Observations & 838 & 822 & 694 & 681 & 606 \\
\hline$R^{2}$ & 0.201 & 0.253 & 0.264 & 0.275 & 0.283 \\
\hline
\end{tabular}


Table B7: Firm liabilities and the likelihood of selling the rights to positive NPV projects. This table reports the results of linear probability models in which the dependent variable is the likelihood of selling a positive net present value $(\mathrm{NPV}+)$ project. The sample is comprised of project-year observations for mining projects from the year the firm publicly discloses the NI 43-101 technical report that includes the initial NPV estimate to the year the firm begins construction on the mine, or the sample period ends, whichever comes first. The sample consists of firms listed on the Toronto Stock Exchange (TSX) or Toronto Stock Exchange Venture (TSXV) and located in Canada over the sample period of 2003 to 2016. $S B / M V$ is the sum of estimated reclamation liabilities of all of a firm's producing mines defined as self-bonded divided by the market value of the firm's assets. $E B / M V$ is the sum of estimated reclamation liabilities of all of a firm's producing mines defined as externally-bonded (guaranteed with a surety bond, letter of credit, etc.) divided by the market value of the firm's assets. $\mathbb{1}_{\mathrm{SB}>\mathrm{NPV}}$ is an indicator variable that equals 1 if the sum of estimated reclamation liabilities of all of a firm's producing mines defined as self-bonded exceeds the initial NPV estimate of the mining project. $\mathbb{1}_{\mathrm{EB}>\mathrm{NPV}}$ is an indicator variable that equals 1 if the sum of estimated reclamation liabilities of all of a firm's producing mines defined as externally-bonded (guaranteed with a surety bond, letter of credit, etc.) exceeds the initial NPV estimate of the mining project. $\mathbb{1}_{\mathrm{TD}}>\mathrm{NPV}$ is an indicator variable that equals 1 if the firm's traditional debt exceeds the initial NPV estimate of the mining project. The data on estimated reclamation liabilities were handcollected from firms' public disclosures. Self-bonded and externally-bonded mines are classified using the self-bonding regulations in Table 1 according to the description in Section 3.1. Accounting variables (defined in Appendix Table 1) are constructed using data from Compustat-North America, the project data were provide by Mining Intelligence and futures data is from Bloomberg. Robust standard errors, clustered at the firm level, are reported in parentheses. *,*, and ${ }^{* * *}$ denote significance at the $10 \%, 5 \%$, and $1 \%$ level, respectively.

\begin{tabular}{|c|c|c|c|c|c|}
\hline \multicolumn{6}{|l|}{ Panel A: Liability ratios } \\
\hline \multirow{2}{*}{ Dependent variable $=$} & \multicolumn{5}{|c|}{ Likelihood of selling the rights to an NPV+ project } \\
\hline & $(1)$ & $(2)$ & $(3)$ & $(4)$ & $(5)$ \\
\hline $\mathrm{SB} / \mathrm{MV}$ & $0.012^{* * *}$ & $0.011 * *$ & $0.009 * *$ & $0.012^{* *}$ & $0.026^{* * *}$ \\
\hline $\mathrm{EB} / \mathrm{MV}$ & -0.001 & -0.001 & -0.000 & -0.001 & -0.000 \\
\hline & $(0.002)$ & $(0.002)$ & $(0.003)$ & $(0.002)$ & $(0.002)$ \\
\hline Market leverage & -0.020 & -0.015 & -0.063 & -0.056 & -0.074 \\
\hline & $(0.050)$ & $(0.051)$ & $(0.050)$ & $(0.050)$ & $(0.065)$ \\
\hline Log of book assets & & -0.004 & 0.002 & 0.000 & 0.010 \\
\hline Cash & & $\begin{array}{l}(0.011) \\
-0.042\end{array}$ & $\begin{array}{l}(0.010) \\
-0.028\end{array}$ & $\begin{array}{l}(0.011) \\
-0.031\end{array}$ & $\begin{array}{l}(0.015) \\
-0.057\end{array}$ \\
\hline & & $(0.049)$ & $(0.046)$ & $(0.049)$ & $(0.059)$ \\
\hline ROA & & 0.008 & 0.007 & 0.006 & 0.003 \\
\hline & & $(0.009)$ & $(0.008)$ & $(0.008)$ & $(0.010)$ \\
\hline Tobin's $Q$ & & 0.007 & $0.010^{*}$ & 0.008 & $0.010^{*}$ \\
\hline & & $(0.004)$ & $(0.005)$ & $(0.005)$ & $(0.006)$ \\
\hline Log of age & & -0.026 & -0.006 & -0.012 & -0.030 \\
\hline & & $(0.025)$ & $(0.025)$ & $(0.027)$ & $(0.030)$ \\
\hline Project NPV (\$100Ms) & & 0.006 & 0.005 & 0.011 & 0.013 \\
\hline Project Capital Costs $(\$ 100 \mathrm{Ms})$ & & 0.002 & 0.002 & 0.000 & 0.000 \\
\hline & & $(0.002)$ & $(0.002)$ & $(0.003)$ & $(0.003)$ \\
\hline Expected mine life & & $-0.004^{*}$ & $\begin{array}{l}-0.003 \\
(0.003)\end{array}$ & $-0.006^{* *}$ & $-0.008^{* *}$ \\
\hline Total NPV of alternative projects $(\$ 100 \mathrm{Ms})$ & & -0.006 & -0.007 & -0.009 & -0.006 \\
\hline & & $(0.007)$ & $(0.007)$ & $(0.008)$ & $(0.007)$ \\
\hline Start alternative NPV+ project & & -0.016 & -0.008 & -0.015 & -0.019 \\
\hline Primary mineral price ( $\%$ ch.) & & $(0.014)$ & $\begin{array}{c}(0.012) \\
0.019 \\
(0.024)\end{array}$ & $(0.014)$ & $(0.021)$ \\
\hline Futures price & & & & -0.003 & -0.005 \\
\hline Options-implied volatility & & & & $(0.005)$ & $\begin{array}{c}(0.005) \\
0.004 \\
(0.037)\end{array}$ \\
\hline Controls for projects in each stage & No & Yes & Yes & Yes & Yes \\
\hline Firm FE & Yes & Yes & Yes & Yes & Yes \\
\hline Year FE & Yes & Yes & Yes & Yes & Yes \\
\hline Primary mineral FE & Yes & Yes & Yes & Yes & Yes \\
\hline Number of firms & 222 & 219 & 184 & 182 & 161 \\
\hline Observations & 1,623 & 1,582 & 1,367 & 1,338 & 1,112 \\
\hline$R^{2}$ & 0.836 & 0.841 & 0.840 & 0.844 & 0.841 \\
\hline
\end{tabular}


Table IA7-Continued

\begin{tabular}{|c|c|c|c|c|c|}
\hline \multirow[t]{2}{*}{ Dependent variable $=$} & \multicolumn{5}{|c|}{ Likelihood of selling the rights to an $\mathrm{NPV}+$ project } \\
\hline & $(1)$ & $(2)$ & $(3)$ & $(4)$ & $(5)$ \\
\hline $\mathbb{1}_{\mathrm{SB} \geq \mathrm{NPV}}$ & $\begin{array}{c}0.076 * * \\
(0.035)\end{array}$ & $\begin{array}{c}0.087^{*} \\
(0.048)\end{array}$ & $\begin{array}{c}0.095^{*} \\
(0.052)\end{array}$ & $\begin{array}{c}0.087 \\
(0.054)\end{array}$ & $\begin{array}{c}0.086 \\
(0.056)\end{array}$ \\
\hline $\mathbb{1}_{\mathrm{EB} \geq \mathrm{NPV}}$ & $\begin{array}{c}0.021 \\
(0.033)\end{array}$ & $\begin{array}{c}0.038 \\
(0.040)\end{array}$ & $\begin{array}{c}0.044 \\
(0.041)\end{array}$ & $\begin{array}{c}0.064 \\
(0.043)\end{array}$ & $\begin{array}{c}0.080 \\
(0.052)\end{array}$ \\
\hline $\mathbb{1}_{\mathrm{TD} \geq \mathrm{NPV}}$ & 0.029 & 0.036 & 0.031 & 0.024 & 0.037 \\
\hline Log of book assets & 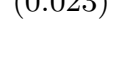 & $\begin{array}{c}(0.025) \\
-0.007 \\
(0.011)\end{array}$ & $\begin{array}{l}(0.020) \\
-0.003 \\
(0.010)\end{array}$ & $\begin{array}{c}(0.026) \\
-0.004 \\
(0.011)\end{array}$ & $\begin{array}{c}(0.031) \\
0.004 \\
(0.015)\end{array}$ \\
\hline Cash & & $\begin{array}{c}-0.041 \\
(0.049)\end{array}$ & $\begin{array}{l}-0.026 \\
(0.046)\end{array}$ & $\begin{array}{c}-0.030 \\
(0.049)\end{array}$ & $\begin{array}{c}-0.057 \\
(0.059)\end{array}$ \\
\hline $\mathrm{ROA}$ & & $\begin{array}{c}0.009 \\
(0.009)\end{array}$ & $\begin{array}{c}0.009 \\
(0.009)\end{array}$ & $\begin{array}{c}0.008 \\
(0.009)\end{array}$ & $\begin{array}{c}0.005 \\
(0.010)\end{array}$ \\
\hline Tobin's $Q$ & & $\begin{array}{c}0.006 \\
(0.004)\end{array}$ & $\begin{array}{l}0.009^{*} \\
(0.005)\end{array}$ & $\begin{array}{c}0.008 \\
(0.005)\end{array}$ & $\begin{array}{c}0.009 \\
(0.006)\end{array}$ \\
\hline Log of age & & $\begin{array}{c}-0.024 \\
(0.026)\end{array}$ & $\begin{array}{l}-0.001 \\
(0.025)\end{array}$ & $\begin{array}{l}-0.005 \\
(0.027)\end{array}$ & $\begin{array}{c}-0.022 \\
(0.031)\end{array}$ \\
\hline Project NPV (\$100Ms) & & $\begin{array}{c}0.009 \\
(0.008)\end{array}$ & $\begin{array}{c}0.009 \\
(0.010)\end{array}$ & $\begin{array}{c}0.016 \\
(0.010)\end{array}$ & $\begin{array}{l}0.019^{*} \\
(0.010)\end{array}$ \\
\hline Project Capital Costs $(\$ 100 \mathrm{Ms})$ & & $\begin{array}{c}0.001 \\
(0.002)\end{array}$ & $\begin{array}{c}0.001 \\
(0.002)\end{array}$ & $\begin{array}{c}-0.001 \\
(0.002)\end{array}$ & $\begin{array}{l}-0.001 \\
(0.002)\end{array}$ \\
\hline Expected mine life & & $\begin{array}{c}-0.002 \\
(0.002)\end{array}$ & $\begin{array}{l}-0.001 \\
(0.002)\end{array}$ & $\begin{array}{c}-0.004 \\
(0.003)\end{array}$ & $\begin{array}{c}-0.005 \\
(0.003)\end{array}$ \\
\hline Total NPV of alternative projects $(\$ 100 \mathrm{Ms})$ & & $\begin{array}{l}-0.010 \\
(0.007)\end{array}$ & $\begin{array}{c}-0.012^{*} \\
(0.007)\end{array}$ & $\begin{array}{r}-0.013^{*} \\
(0.008)\end{array}$ & $\begin{array}{c}-0.010 \\
(0.008)\end{array}$ \\
\hline Start alternative NPV + project & & $\begin{array}{l}-0.021 \\
(0.014)\end{array}$ & $\begin{array}{l}-0.015 \\
(0.013)\end{array}$ & $\begin{array}{l}-0.021 \\
(0.015)\end{array}$ & $\begin{array}{l}-0.026 \\
(0.020)\end{array}$ \\
\hline Primary mineral price ( $\%$ ch.) & & & $\begin{array}{c}0.020 \\
(0.023)\end{array}$ & & \\
\hline Futures price & & & & $\begin{array}{l}-0.001 \\
(0.005)\end{array}$ & $\begin{array}{l}-0.002 \\
(0.005)\end{array}$ \\
\hline Options-implied volatility & & & & & $\begin{array}{c}-0.001 \\
(0.034)\end{array}$ \\
\hline Controls for projects in each stage & No & Yes & Yes & Yes & Yes \\
\hline Firm FE & Yes & Yes & Yes & Yes & Yes \\
\hline Year FE & Yes & Yes & Yes & Yes & Yes \\
\hline Primary mineral FE & Yes & Yes & Yes & Yes & Yes \\
\hline Number of firms & 222 & 219 & 184 & 182 & 161 \\
\hline Observations & 1,623 & 1,582 & 1,367 & 1,338 & 1,112 \\
\hline$R^{2}$ & 0.836 & 0.842 & 0.840 & 0.845 & 0.842 \\
\hline
\end{tabular}


Table B8: Excluding local reclamation liabilities for firms headquartered in a province at the time of the law change. This table reports the results of linear probability models. The dependent variable in Models (1) and (2) is the likelihood a firm acquires the rights to a new positive net present value $(\mathrm{NPV}+)$ mining project. The NPV of the mining rights is defined as the value of the NPV estimate in the NI 43-101 technical reports less the cost the acquiring firm paid for the individual mine at acquisition. The sample in Models (1) and (2) consists of firms listed on the Toronto Stock Exchange (TSX) or Toronto Stock Exchange Venture (TSXV) and located in Canada over the sample period of 1990 to 2016. The dependent variable for Models (3) through (6) is the likelihood of beginning construction on a positive net present value $(\mathrm{NPV}+)$ project. The sample is comprised of project-year observations for mining projects from the year the firm publicly discloses the NI 43-101 technical report that includes the initial NPV estimate to the year the firm begins construction on the mine, or the sample period ends, whichever comes first. The sample in Models (3) through (6) consists of firms listed on the Toronto Stock Exchange (TSX) or Toronto Stock Exchange Venture (TSXV) and located in Canada over the sample period of 2003 to 2016. $S B / M V_{\text {No } \mathrm{HQ}}$ is the sum of estimated reclamation liabilities of all of a firm's producing mines defined as self-bonded and located outside a firm's headquarter state if the firm operated at the time of the law change, divided by the market value of the firm's assets. $E B / M V_{\mathrm{No}} \mathrm{HQ}$ is the sum of estimated reclamation liabilities of all of a firm's producing mines defined as externally-bonded (guaranteed with a surety bond, letter of credit, etc.) and located outside a firm's headquarter state if the firm operated at the time of the law change, divided by the market value of the firm's assets. $\mathbb{1}_{\mathrm{SB} \geq \mathrm{NPV}}$, No HQ is an indicator variable that equals 1 if the sum of estimated reclamation liabilities of all of a firm's producing mines defined as self-bonded and located outside a firm's headquarter state if the firm operated at the time of the law change exceeds the initial NPV estimate of the mining project. $\mathbb{1}_{\mathrm{EB} \geq \mathrm{NPV}}$, No HQ is an indicator variable that equals 1 if the sum of estimated reclamation liabilities of all of a firm's producing mines defined as externally-bonded (guaranteed with a surety bond, letter of credit, etc.) and located outside a firm's headquarter state if the firm operated at the time of the law change exceeds the initial NPV estimate of the mining project. $\mathbb{1}_{\mathrm{TD} \geq \mathrm{NPV}}$ is an indicator variable that equals 1 if the firm's traditional debt exceeds the initial NPV estimate of the mining project. The data on estimated reclamation liabilities were hand-collected from firms' public disclosures. Self-bonded and externally-bonded mines are classified using the self-bonding regulations in Table 1 according to the description in Section 3.1. The additional control variables in Models (1) and (2) are the same as those in Table 5, Model (5) of the main text and the additional control variables in Models (3) through (6) are the same as those in Table 6, Model (2). The accounting variables (defined in Appendix Table 1) are constructed using data from Compustat-North America and the data on firms' mining projects is provided by Mining Intelligence. Robust standard errors, clustered at the firm level, are reported in parentheses. *,**, and *** denote significance at the $10 \%, 5 \%$, and $1 \%$ level, respectively.

\begin{tabular}{|c|c|c|c|c|c|c|}
\hline \multirow[t]{2}{*}{ Dependent variable $=$} & \multicolumn{2}{|c|}{ Acquire rights } & \multicolumn{4}{|c|}{ Begin construction } \\
\hline & $(1)$ & $(2)$ & $(3)$ & $(4)$ & $(5)$ & $(6)$ \\
\hline $\mathrm{SB} / \mathrm{MV}_{\text {No HQ }}$ & $\begin{array}{c}-0.022^{* * *} \\
(0.008)\end{array}$ & $\begin{array}{c}-0.025^{* * *} \\
(0.006)\end{array}$ & $\begin{array}{c}-0.046^{* * *} \\
(0.015)\end{array}$ & $\begin{array}{c}-0.055^{* * *} \\
(0.015)\end{array}$ & & \\
\hline $\mathrm{EB} / \mathrm{MV}_{\text {No } \mathrm{HQ}}$ & $\begin{array}{c}0.001 \\
(0.001)\end{array}$ & $\begin{array}{c}0.001 \\
(0.001)\end{array}$ & $\begin{array}{c}0.008 \\
(0.059)\end{array}$ & $\begin{array}{l}-0.007 \\
(0.063)\end{array}$ & & \\
\hline Market leverage & $\begin{array}{l}-0.014 \\
(0.015)\end{array}$ & $\begin{array}{l}-0.026 \\
(0.016)\end{array}$ & $\begin{array}{l}-0.002 \\
(0.059)\end{array}$ & $\begin{array}{c}-0.016 \\
(0.058)\end{array}$ & & \\
\hline $\mathbb{1}_{\mathrm{SB} \geq \mathrm{NPV}, \text { No HQ }}$ & & & & & $\begin{array}{c}-0.236^{* *} \\
(0.116)\end{array}$ & $\begin{array}{c}-0.233^{* *} \\
(0.090)\end{array}$ \\
\hline $\mathbb{1}_{\mathrm{EB} \geq \mathrm{NPV}}$, No HQ & & & & & $\begin{array}{c}0.016 \\
(0.071)\end{array}$ & $\begin{array}{l}-0.007 \\
(0.080)\end{array}$ \\
\hline $\mathbb{1}_{\mathrm{TD} \geq \mathrm{NPV}}$ & & & & & $\begin{array}{l}-0.027 \\
(0.073)\end{array}$ & $\begin{array}{c}-0.046 \\
(0.075)\end{array}$ \\
\hline Additional controls & No & Yes & No & Yes & No & Yes \\
\hline Firm FE & Yes & Yes & Yes & Yes & Yes & Yes \\
\hline Year FE & Yes & Yes & Yes & Yes & Yes & Yes \\
\hline Number of firms & 790 & 775 & 176 & 173 & 176 & 174 \\
\hline Observations & 7,083 & 6,747 & 828 & 812 & 828 & 822 \\
\hline$R^{2}$ & 0.128 & 0.152 & 0.290 & 0.300 & 0.292 & 0.302 \\
\hline
\end{tabular}


Table B9: Number of new rights and permits around the passage of self-bonding laws. This table reports the results of linear regression models in which the dependent variables are the number of new mining rights acquired, and the number of new permits, respectively, by location. Models (1) and (2) look at the total number of new rights and permits in all locations by all firms, Models (3) and (4) look at new rights and permits in all locations by firms with a history of mining in the jurisdiction, and Models (5) and (6) look at new rights and permits in Canada by firms headquartered in the location of the regulation change. Self-bonding regulations are listed in Table 1. The data on new rights and permits is from Mining Intelligence. Robust standard errors, clustered at the location of regulation level, are reported in parentheses. ${ }^{* * *}$, and ${ }^{* * *}$ denote significance at the $10 \%, 5 \%$, and $1 \%$ level, respectively.

\begin{tabular}{|c|c|c|c|c|c|c|}
\hline \multirow[t]{3}{*}{ Dependent variable $=$} & New rights & New permits & New rights & New permits & New rights & New permits \\
\hline & \multicolumn{2}{|c|}{ By all firms } & \multicolumn{2}{|c|}{$\begin{array}{l}\text { By firms with prior mines } \\
\text { in location of regulation }\end{array}$} & \multicolumn{2}{|c|}{$\begin{array}{c}\text { By firms HQ'ed } \\
\text { in location of regulation }\end{array}$} \\
\hline & (1) & $(2)$ & $(3)$ & (4) & $(5)$ & $(6)$ \\
\hline Self-bonding allowed & $\begin{array}{c}0.250 \\
(0.187)\end{array}$ & $\begin{array}{c}0.647 \\
(1.501)\end{array}$ & $\begin{array}{l}-0.001 \\
(0.058)\end{array}$ & $\begin{array}{c}0.931 \\
(1.060)\end{array}$ & $\begin{array}{l}0.246 \\
(0.270)\end{array}$ & $\begin{array}{l}1.939 \\
(5.890)\end{array}$ \\
\hline $\begin{array}{l}\text { Country FE } \\
\text { Regulatory jurisdiction FE } \\
\text { Year FE }\end{array}$ & $\begin{array}{l}\text { Yes } \\
\text { Yes } \\
\text { Yes }\end{array}$ & $\begin{array}{l}\text { Yes } \\
\text { Yes } \\
\text { Yes }\end{array}$ & $\begin{array}{l}\text { Yes } \\
\text { Yes } \\
\text { Yes }\end{array}$ & $\begin{array}{l}\text { Yes } \\
\text { Yes } \\
\text { Yes }\end{array}$ & $\begin{array}{l}\text { Yes } \\
\text { Yes } \\
\text { Yes }\end{array}$ & $\begin{array}{l}\text { Yes } \\
\text { Yes } \\
\text { Yes }\end{array}$ \\
\hline $\begin{array}{l}\text { Observations } \\
R^{2}\end{array}$ & $\begin{array}{l}3,052 \\
0.310\end{array}$ & $\begin{array}{l}3,052 \\
0.417\end{array}$ & $\begin{array}{l}3,052 \\
0.232\end{array}$ & $\begin{array}{l}3,052 \\
0.370\end{array}$ & $\begin{array}{c}364 \\
0.345\end{array}$ & $\begin{array}{c}364 \\
0.479\end{array}$ \\
\hline
\end{tabular}


Table B10: Separating the bonding and investment decision makers. This table reports the results of linear probability models. The dependent variable in Models (1) and (2) is the likelihood a firm acquires the rights to a new positive net present value (NPV+) mining project. The NPV of the mining rights is defined as the value of the NPV estimate in the NI 43-101 technical reports less the cost the acquiring firm paid for the individual mine at acquisition. The sample in Models (1) and (2) consists of firms listed on the Toronto Stock Exchange (TSX) or Toronto Stock Exchange Venture (TSXV) and located in Canada over the sample period of 1990 to 2016. The dependent variable for Models (3) through (6) is the likelihood of beginning construction on a positive net present value (NPV+) project. The sample is comprised of project-year observations for mining projects from the year the firm publicly discloses the NI 43-101 technical report that includes the initial NPV estimate to the year the firm begins construction on the mine, or the sample period ends, whichever comes first. The sample in Models (3) through (6) consists of firms listed on the Toronto Stock Exchange (TSX) or Toronto Stock Exchange Venture (TSXV) and located in Canada over the sample period of 2003 to 2016. $S B / M V_{\text {Different CEOs }}$ is the sum of estimated reclamation liabilities of all of a firm's producing mines defined as self-bonded and created under the direction of a CEO who is not the CEO at the time of the investment decision, divided by the market value of the firm's assets. $E B / M V_{\text {Different CEOs }}$ is the sum of estimated reclamation liabilities of all of a firm's producing mines defined as externally-bonded (guaranteed with a surety bond, letter of credit, etc.) and created under the direction of a CEO who is not the CEO at the time of the investment decision, divided by the market value of the firm's assets. $\mathbb{1}_{\mathrm{SB}>\mathrm{NPV}}$, Different CEOs is an indicator variable that equals 1 if the sum of estimated reclamation liabilities of all of a firm's producing mines defined as self-bonded and created under the direction of a $\mathrm{CEO}$ who is not the $\mathrm{CEO}$ at the time of the investment decision exceeds the initial NPV estimate of the mining project. $\mathbb{1}_{\mathrm{EB} \geq \mathrm{NPV}}$, Different CEOs is an indicator variable that equals 1 if the sum of estimated reclamation liabilities of all of a firm's producing mines defined as externally-bonded (guaranteed with a surety bond, letter of credit, etc.) and created under the direction of a CEO who is not the CEO at the time of the investment decision exceeds the initial NPV estimate of the mining project. $\mathbb{1}_{\mathrm{TD} \geq \mathrm{NPV}}$ is an indicator variable that equals 1 if the firm's traditional debt exceeds the initial NPV estimate of the mining project. The data on estimated reclamation liabilities were hand-collected from firms' public disclosures. Self-bonded and externally-bonded mines are classified using the self-bonding regulations in Table 1 according to the description in Section 3.1. The additional control variables in Models (1) and (2) are the same as those in Table 5, Model (5) of the main text and the additional control variables in Models (3) through (6) are the same as those in Table 6, Model (2). The accounting variables (defined in Appendix Table 1) are constructed using data from Compustat - North America and the data on firms' mining projects is provided by Mining Intelligence. Robust standard errors, clustered at the firm level, are reported in parentheses. $*, * *$, and $* * *$ denote significance at the $10 \%, 5 \%$, and $1 \%$ level, respectively.

\begin{tabular}{|c|c|c|c|c|c|c|}
\hline \multirow[t]{2}{*}{ Dependent variable $=$} & \multicolumn{2}{|c|}{ Acquire rights } & \multicolumn{4}{|c|}{ Begin construction } \\
\hline & $(1)$ & $(2)$ & $(3)$ & $(4)$ & (5) & (6) \\
\hline $\mathrm{SB} / \mathrm{MV}_{\text {Different CEOs }}$ & $\begin{array}{c}-0.022^{* * *} \\
(0.008)\end{array}$ & $\begin{array}{c}-0.025^{* * *} * \\
(0.006)\end{array}$ & $\begin{array}{c}-0.047^{* * *} * \\
(0.015)\end{array}$ & $\begin{array}{c}-0.055^{* * *} * \\
(0.015)\end{array}$ & & \\
\hline $\mathrm{EB} / \mathrm{MV}_{\text {Different CEOs }}$ & $\begin{array}{c}0.001 \\
(0.001)\end{array}$ & $\begin{array}{c}0.001 \\
(0.001)\end{array}$ & $\begin{array}{l}-0.005 \\
(0.058)\end{array}$ & $\begin{array}{l}-0.015 \\
(0.062)\end{array}$ & & \\
\hline Market leverage & $\begin{array}{c}-0.014 \\
(0.015)\end{array}$ & $\begin{array}{l}-0.026 \\
(0.016)\end{array}$ & $\begin{array}{c}0.009 \\
(0.059)\end{array}$ & $\begin{array}{l}-0.009 \\
(0.057)\end{array}$ & & \\
\hline $\mathbb{1}_{\mathrm{SB} \geq \mathrm{NPV}}$, Different CEOs & & & & & $\begin{array}{c}-0.248^{* *} \\
(0.118)\end{array}$ & $\begin{array}{l}-0.159 \\
(0.111)\end{array}$ \\
\hline $\mathbb{1}_{\mathrm{EB} \geq \mathrm{NPV}}$, Different CEOs & & & & & $\begin{array}{c}0.035 \\
(0.072)\end{array}$ & $\begin{array}{c}0.041 \\
(0.087)\end{array}$ \\
\hline $\mathbb{1}_{\mathrm{TD} \geq \mathrm{NPV}}$ & & & & & $\begin{array}{l}-0.021 \\
(0.067)\end{array}$ & $\begin{array}{c}-0.038 \\
(0.071)\end{array}$ \\
\hline Additional controls & No & Yes & No & Yes & No & Yes \\
\hline Firm FE & Yes & Yes & Yes & Yes & Yes & Yes \\
\hline Year FE & Yes & Yes & Yes & Yes & Yes & Yes \\
\hline Number of firms & 790 & 775 & 176 & 173 & 176 & 174 \\
\hline Observations & 7,083 & 6,747 & 828 & 812 & 828 & 822 \\
\hline$R^{2}$ & 0.128 & 0.152 & 0.291 & 0.301 & 0.292 & 0.299 \\
\hline
\end{tabular}


Table B11: Rethinking the grandfathering assumption. This table reports the results of linear probability models. The dependent variable in Models (1) and (2) is the likelihood a firm acquires the rights to a new positive net present value $(\mathrm{NPV}+)$ mining project. The NPV of the mining rights is defined as the value of the NPV estimate in the NI 43-101 technical reports less the cost the acquiring firm paid for the individual mine at acquisition. The sample in Models (1) and (2) consists of firms listed on the Toronto Stock Exchange (TSX) or Toronto Stock Exchange Venture (TSXV) and located in Canada over the sample period of 1990 to 2016. The dependent variable for Models (3) through (6) is the likelihood of beginning construction on a positive net present value $(\mathrm{NPV}+)$ project. The sample is comprised of project-year observations for mining projects from the year the firm publicly discloses the NI 43-101 technical report that includes the initial NPV estimate to the year the firm begins construction on the mine, or the sample period ends, whichever comes first. The sample in Models (3) through (6) consists of firms listed on the Toronto Stock Exchange (TSX) or Toronto Stock Exchange Venture (TSXV) and located in Canada over the sample period of 2003 to 2016. $S B / M V$ is the sum of estimated reclamation liabilities of all of a firm's producing mines defined as self-bonded, divided by the market value of the firm's assets. $E B / M V$ is the sum of estimated reclamation liabilities of all of a firm's producing mines defined as externally-bonded (guaranteed with a surety bond, letter of credit, etc.), divided by the market value of the firm's assets. $\mathbb{1}_{\mathrm{SB} \geq \mathrm{NPV}}$ is an indicator variable that equals 1 if the sum of estimated reclamation liabilities of all of a firm's producing mines defined as self-bonded exceeds the initial NPV estimate of the mining project. $\mathbb{1}_{\mathrm{EB} \geq \mathrm{NPV}}$ is an indicator variable that equals 1 if the sum of estimated reclamation liabilities of all of a firm's producing mines defined as externally-bonded (guaranteed with a surety bond, letter of credit, etc.) exceeds the initial NPV estimate of the mining project. $\mathbb{1}_{\mathrm{TD}>\mathrm{NPV}}$ is an indicator variable that equals 1 if the firm's traditional debt exceeds the initial NPV estimate of the mining project. The data on estimated reclamation liabilities were hand-collected from firms' public disclosures. Self-bonded and externally-bonded mines are classified using the self-bonding regulations in Table 1. However, in this table the grandfathering assumption is flipped. That is, outside of U.S. 43 C.F.R. $§ 3809$, I assume all other regulators force mining operators to switch to external bonds at the onset of new regulation. The additional control variables in Models (1) and (2) are the same as those in Table 5, Model (5) of the main text and the additional control variables in Models (3) through (6) are the same as those in Table 6, Model (2). The accounting variables (defined in Appendix Table 1) are constructed using data from Compustat-North America and the data on firms' mining projects is provided by Mining Intelligence. Robust standard errors, clustered at the firm level, are reported in parentheses. ${ }^{*}, * *$, and $* * *$ denote significance at the $10 \%, 5 \%$, and $1 \%$ level, respectively.

\begin{tabular}{|c|c|c|c|c|c|c|}
\hline \multirow[t]{2}{*}{ Dependent variable $=$} & \multicolumn{2}{|c|}{ Acquire rights } & \multicolumn{4}{|c|}{ Begin construction } \\
\hline & $(1)$ & $(2)$ & (3) & $(4)$ & $(5)$ & $(6)$ \\
\hline $\mathrm{SB} / \mathrm{MV}$ & $\begin{array}{c}-0.022 * * * \\
(0.008)\end{array}$ & $\begin{array}{c}-0.024^{* * *} \\
(0.007)\end{array}$ & $\begin{array}{c}-0.046^{* * *} \\
(0.014)\end{array}$ & $\begin{array}{c}-0.055^{* * *} \\
(0.014)\end{array}$ & & \\
\hline $\mathrm{EB} / \mathrm{MV}$ & $\begin{array}{c}0.001 \\
(0.001)\end{array}$ & $\begin{array}{c}0.001 \\
(0.001)\end{array}$ & $\begin{array}{c}0.028 \\
(0.061)\end{array}$ & $\begin{array}{c}0.011 \\
(0.062)\end{array}$ & & \\
\hline Market leverage & $\begin{array}{l}-0.014 \\
(0.015)\end{array}$ & $\begin{array}{c}-0.026 \\
(0.016)\end{array}$ & $\begin{array}{c}0.009 \\
(0.058)\end{array}$ & $\begin{array}{l}-0.008 \\
(0.056)\end{array}$ & & \\
\hline $\mathbb{1}_{\mathrm{SB} \geq \mathrm{NPV}}$ & & & & & $\begin{array}{c}-0.329^{* *} \\
(0.154)\end{array}$ & $\begin{array}{c}-0.317^{*} \\
(0.186)\end{array}$ \\
\hline $\mathbb{1}_{\mathrm{EB} \geq \mathrm{NPV}}$ & & & & & $\begin{array}{c}0.007 \\
(0.068)\end{array}$ & $\begin{array}{l}-0.030 \\
(0.082)\end{array}$ \\
\hline $\mathbb{1}_{\mathrm{TD} \geq \mathrm{NPV}}$ & & & & & $\begin{array}{l}-0.020 \\
(0.066)\end{array}$ & $\begin{array}{l}-0.038 \\
(0.071)\end{array}$ \\
\hline Additional controls & No & Yes & No & Yes & No & Yes \\
\hline Firm FE & Yes & Yes & Yes & Yes & Yes & Yes \\
\hline Year FE & Yes & Yes & Yes & Yes & Yes & Yes \\
\hline Number of firms & 790 & 775 & 177 & 174 & 177 & 174 \\
\hline Observations & 7,083 & 6,747 & 838 & 822 & 838 & 822 \\
\hline$R^{2}$ & 0.128 & 0.151 & 0.289 & 0.299 & 0.291 & 0.300 \\
\hline
\end{tabular}


Table B12: Which firms self-bond in the U.S. This table reports the results of linear regression models. This secondary sample consists of mining firms incorporated in the United States over the period of 1992 to 2016 that self-disclose reclamation liabilities in annual reports. The dependent variable in Models (1) and (2) is an indicator variable that is equal to one if a firm has positive disclosed selfbonded reclamation liabilities. The dependent variable in Models (3) and (4) is $S B / M V$, defined as the total amount of disclosed self-bonded reclamation liabilities divided by the market value of the firm's assets. $E B / M V$ is total amount of disclosed externally-bonded (guaranteed with a surety bond, letter of credit, etc.) reclamation liabilities divided by the market value of the firm's assets. Accounting variables (defined in Appendix Table 1) are constructed using data from Compustat-North America. Robust standard errors, clustered at the firm level, are reported in parentheses. ${ }^{*}, * *$, and ${ }^{* * *}$ denote significance at the $10 \%, 5 \%$, and $1 \%$ level, respectively.

\begin{tabular}{lccccc}
\hline Dependent variable $=$ & \multicolumn{2}{c}{$\mathbb{1}_{S B>0}$} & & \multicolumn{2}{c}{$\mathrm{SB} / \mathrm{MV}$} \\
\cline { 2 - 3 } \cline { 5 - 6 } & $(1)$ & $(2)$ & & $(3)$ & $(4)$ \\
\hline EB/MV & -0.008 & -0.000 & & -0.002 & -0.002 \\
& $(0.034)$ & $(0.016)$ & & $(0.002)$ & $(0.002)$ \\
Market leverage & 0.045 & -0.110 & & 0.021 & 0.028 \\
& $(0.319)$ & $(0.120)$ & & $(0.021)$ & $(0.022)$ \\
Log of book assets & $0.123^{* * *}$ & 0.110 & & 0.003 & -0.002 \\
& $(0.044)$ & $(0.073)$ & & $(0.002)$ & $(0.005)$ \\
Cash & 0.244 & 0.041 & & 0.005 & -0.002 \\
& $(0.388)$ & $(0.117)$ & & $(0.019)$ & $(0.010)$ \\
ROA & -0.389 & -0.165 & & -0.022 & 0.002 \\
& $(0.284)$ & $(0.111)$ & & $(0.019)$ & $(0.012)$ \\
Tobin's $Q$ & -0.016 & 0.008 & & -0.001 & 0.001 \\
& $(0.039)$ & $(0.016)$ & & $0.002)$ & $(0.002)$ \\
Log of firm age & $-0.008^{* *}$ & $0.031^{* * *}$ & & $-0.000 * *$ & $0.002^{* * *}$ \\
& $(0.003)$ & $(0.003)$ & & $(0.000)$ & $(0.000)$ \\
Firm FE & & & & \\
Year FE & No & Yes & No & Yes \\
Data used & Yes & Yes & Yes & Yes \\
& $10-\mathrm{k}$ & $10-\mathrm{k}$ & & $10-\mathrm{k}$ & $10-\mathrm{k}$ \\
Number of firms & 43 & 39 & & 43 & 39 \\
Observations & 342 & 338 & 342 & 338 \\
$R^{2}$ & 0.286 & 0.875 & 0.178 & 0.636 \\
\hline
\end{tabular}


Table B13: Risky firm liabilities and investment in the U.S. This table reports the results of linear regression models in which the dependent variable is capital expenditures (as a percentage of a firm's total book assets). In Models (1) and (2), the sample consists of mining firms incorporated in the United States over the period of 1992 to 2016 that self-disclose reclamation liabilities in annual reports. $S B / M V$ is total amount of disclosed self-bonded reclamation liabilities divided by the market value of the firm's assets. $E B / M V$ is total amount of disclosed externally-bonded (guaranteed with a surety bond, letter of credit, etc.) reclamation liabilities divided by the market value of the firm's assets. $\mathbb{1}_{\mathrm{SB}>0}$ is an indicator variable that equals 1 if the firm has a positive amount of self-bonds. In Model (3), I use data from the Mine Safety and Health Administration (MSHA) on the location and status of a firm's mines to calculate the number of mines defined as self-bonded and externally-bonded using the self-bonding regulations in Table 1 according to the description in Section 3.1. High probability of default is an indicator variable that takes a value of 1 if a firm-year observation is in the top 10 percentile in terms of Shumway distance to default. Accounting variables (defined in Appendix Table 1) are constructed using data from Compustat-North America. Robust standard errors, clustered at the firm level, are reported in parentheses. ${ }^{*}, * *$, and ${ }^{* * *}$ denote significance at the $10 \%, 5 \%$, and $1 \%$ level, respectively.

\begin{tabular}{|c|c|c|c|}
\hline \multirow[t]{2}{*}{ Dependent variable $=$} & \multicolumn{3}{|c|}{ Capital expenditures } \\
\hline & $(1)$ & $(2)$ & $(3)$ \\
\hline $\mathrm{SB} / \mathrm{MV}$ & $\begin{array}{c}0.0790 \\
(0.1126)\end{array}$ & & \\
\hline $\mathrm{EB} / \mathrm{MV}$ & $\begin{array}{l}-0.0145 \\
(0.0233)\end{array}$ & & \\
\hline $\mathbb{1}_{\mathrm{SB} \geq 0}$ & & $\begin{array}{c}-0.0184^{*} \\
(0.0108)\end{array}$ & \\
\hline$\#$ of self-bonded mines & & & $\begin{array}{c}0.0004 \\
(0.0004)\end{array}$ \\
\hline $\mathrm{SB} / \mathrm{MV} \times$ high probability of default & $\begin{array}{l}-0.2029^{*} \\
(0.1177)\end{array}$ & & \\
\hline $\mathrm{EB} / \mathrm{MV} \times$ high probability of default & $\begin{array}{l}0.0040 \\
(0.0242)\end{array}$ & & \\
\hline $\mathbb{1}_{\mathrm{SB} \geq 0} \times$ high probability of default & & $\begin{array}{l}-0.0039 \\
(0.0083)\end{array}$ & \\
\hline \# of self-bonded mines $\times$ high probability of default & & & $\begin{array}{c}-0.0002^{* *} \\
(0.0001)\end{array}$ \\
\hline Market leverage & $\begin{array}{c}0.0088 \\
(0.0422)\end{array}$ & $\begin{array}{c}0.0025 \\
(0.0403)\end{array}$ & \\
\hline Market leverage $\times$ high probability of default & $\begin{array}{l}-0.0173 \\
(0.0351)\end{array}$ & $\begin{array}{l}-0.0275 \\
(0.0319)\end{array}$ & $\begin{array}{c}0.0080 \\
(0.0128)\end{array}$ \\
\hline Log of book assets & $\begin{array}{c}0.0099 \\
(0.0159)\end{array}$ & $\begin{array}{c}0.0120 \\
(0.0150)\end{array}$ & $\begin{array}{l}-0.0035 \\
(0.0033)\end{array}$ \\
\hline Cash & $\begin{array}{c}-0.0687^{* *} \\
(0.0339)\end{array}$ & $\begin{array}{l}-0.0275 \\
(0.0348)\end{array}$ & $\begin{array}{c}-0.0916^{* * *} \\
(0.0173)\end{array}$ \\
\hline ROA & $\begin{array}{l}-0.0384 \\
(0.0234)\end{array}$ & $\begin{array}{l}-0.0386 \\
(0.0235)\end{array}$ & $\begin{array}{c}0.0420 \\
(0.0266)\end{array}$ \\
\hline Tobin's $Q$ & $\begin{array}{c}0.0280^{* * *} \\
(0.0067)\end{array}$ & $\begin{array}{c}0.0246^{* * *} \\
(0.0054)\end{array}$ & $\begin{array}{c}0.0149^{* * *} \\
(0.0048)\end{array}$ \\
\hline Log of firm age & $\begin{array}{l}-0.0009 \\
(0.0011)\end{array}$ & $\begin{array}{c}0.0001 \\
(0.0009)\end{array}$ & $\begin{array}{l}0.0006 \\
(0.0049)\end{array}$ \\
\hline Firm fixed effects & Yes & Yes & Yes \\
\hline Year fixed effects & Yes & Yes & Yes \\
\hline Data used & $10-\mathrm{k}$ & $10-\mathrm{k}$ & MSHA \\
\hline Number of firms & 39 & 42 & 120 \\
\hline Observations & 338 & 359 & 1,453 \\
\hline$R^{2}$ & 0.684 & 0.684 & 0.584 \\
\hline
\end{tabular}

